Werner Weiss | Franz Mauther

\title{
SOLAR HeAt WorLdWide
}

Markets and Contribution to the Energy Supply 2010

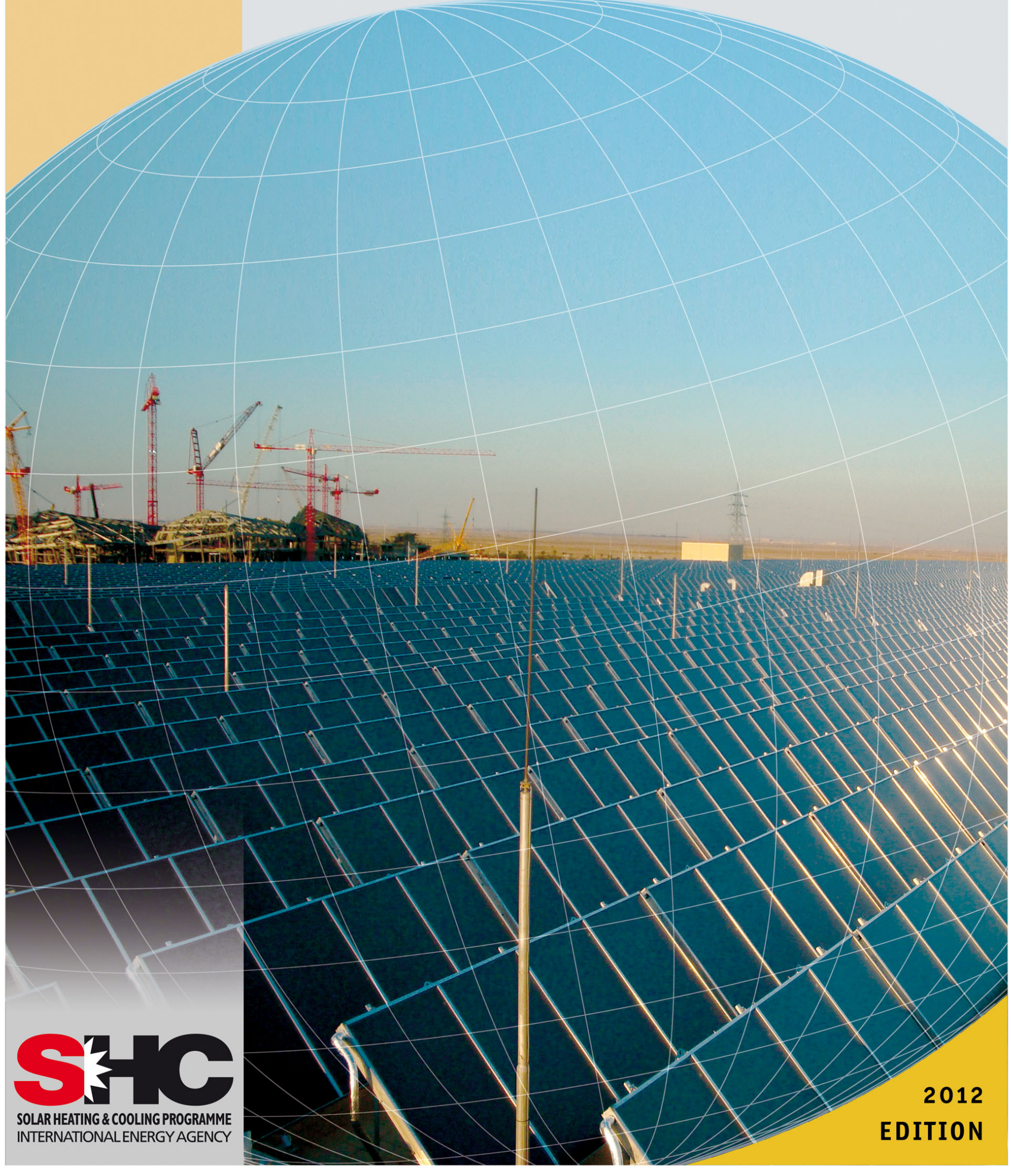





\section{SOLAR HEAT WORLDWIDE}

\section{Markets and Contribution to the Energy Supply 2010}

EDITION 2012

Werner Weiss and Franz Mauthner

AEE INTEC

AEE - Institute for Sustainable Technologies

A-8200 Gleisdorf, Austria

IEA Solar Heating \& Cooling Programme, May 2012

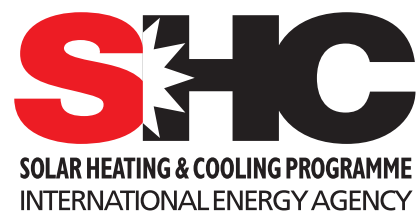

Supported by the Austrian Ministry for Transport, Innovation and Technology

\section{bmart}

Cover: World's largest solar thermal plant at Princess Noura Bint Abdulrahman University for Women in Riyadh, Saudi Arabia (Photo: Millenium Energy Industry)

Design, Grafics, Typesetting \& Imageprocessing: STEINHUBER INFODESIGN, Graz, Austria

Notice:

The Solar Heating and Cooling Programme functions within a framework created by the International Energy Agency (IEA). Views, findings and publications of the Solar Heating and Cooling Programme do not necessarily represent the views or policies of the IEA Secretariat or of all its individual member countries. 


\section{Table of Contents}

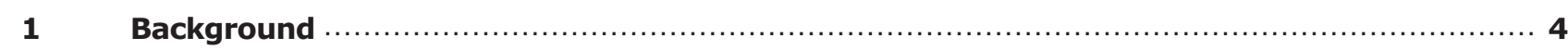

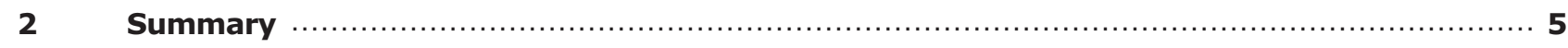

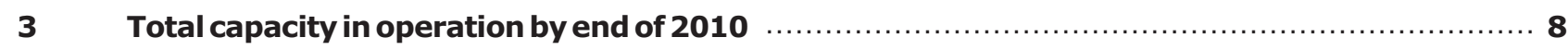

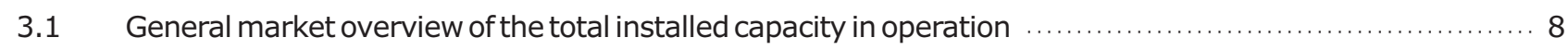

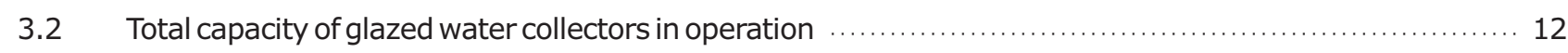

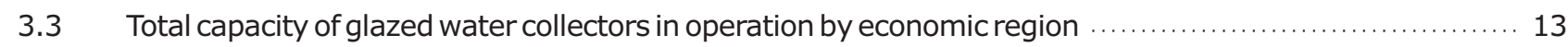

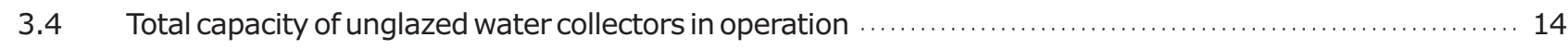

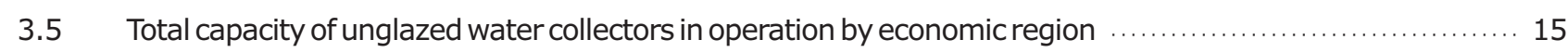

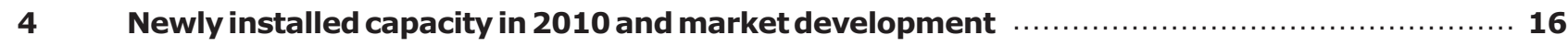

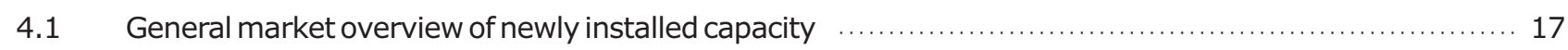

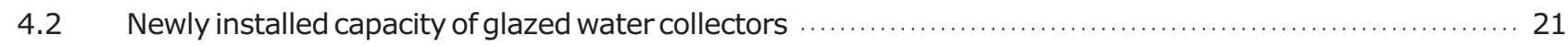

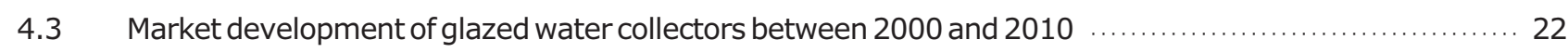

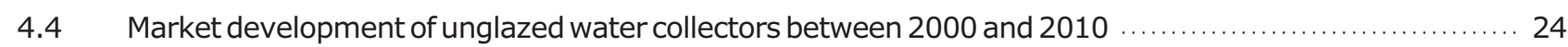

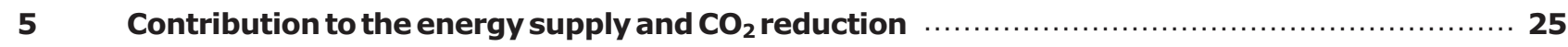

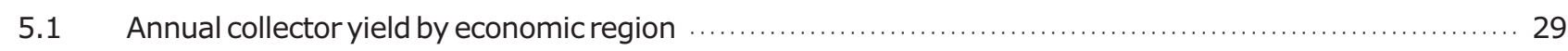

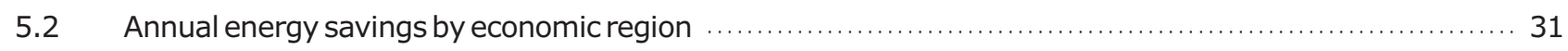

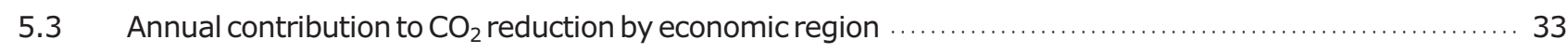

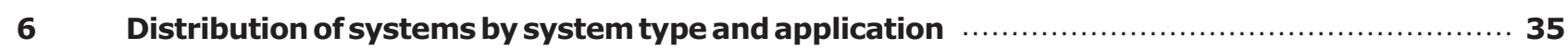

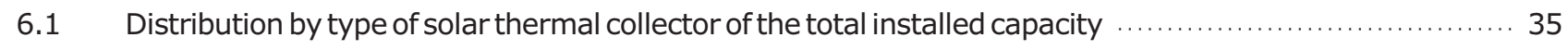

6.2 Distribution by type of solar thermal collector of the newly installed capacity in $2010 \ldots \ldots \ldots \ldots \ldots \ldots \ldots \ldots \ldots \ldots \ldots$

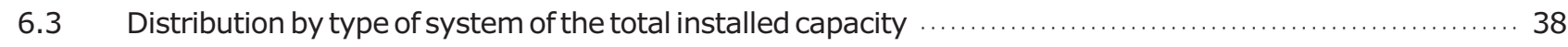

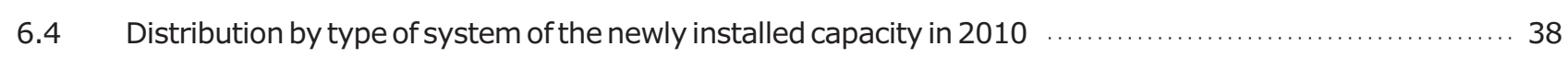

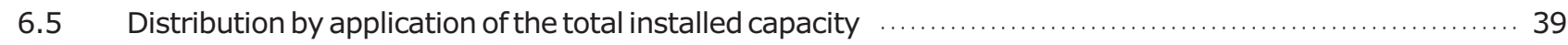

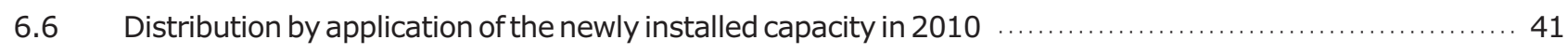

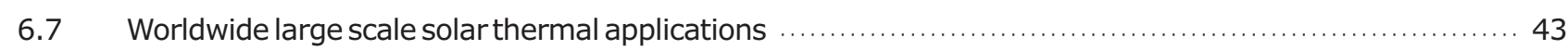

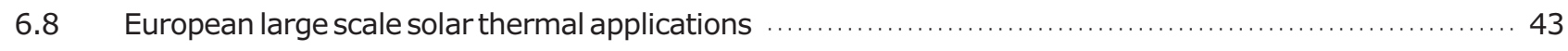

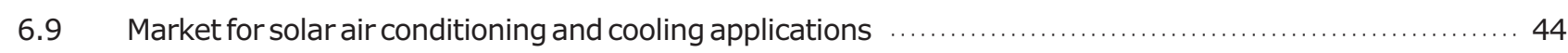

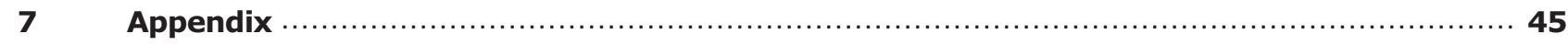

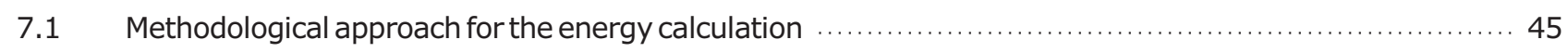

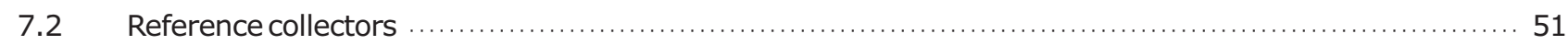

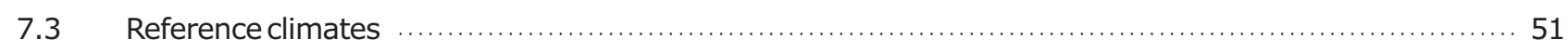

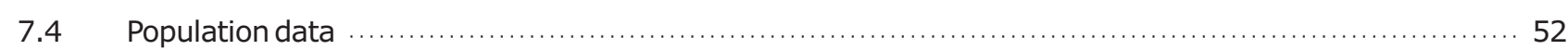

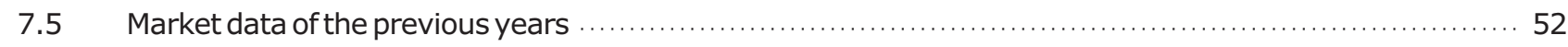

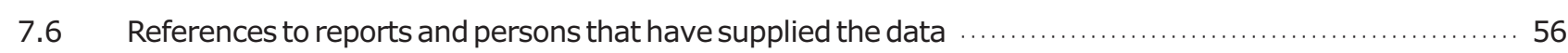

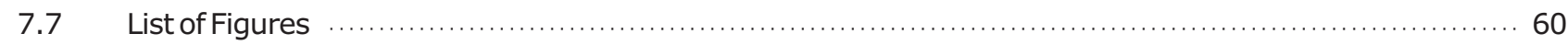

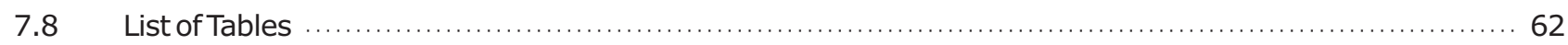




\section{$1 \quad$ Background}

This report was prepared within the framework of the Solar Heating and Cooling Programme (SHC) of the International Energy Agency (IEA). The goal of the report is to document the solar thermal capacity installed in the important markets worldwide, and to ascertain the contribution of solar thermal systems to the supply of energy and the $\mathrm{CO}_{2}$ emissions avoided as a result of operating these systems. The collectors documented are unglazed collectors, glazed flat-plate collectors (FPC) and evacuated tube collectors (ETC) with water as the energy carrier as well as glazed and unglazed air collectors.

The data were collected from a questionnaire survey of the national delegates of the SHC Programme's Executive Committee and other national experts active in the field of solar thermal energy. As some of the 55 countries included in this report have very detailed statistics and others have only estimates from experts, the data was checked for its plausibility on the basis of various publications.

Starting with the collector area, respectively the capacity installed, the contributions of solar thermal systems towards the supply of energy and the reduction of $\mathrm{CO}_{2}$ were ascertained.

The 55 countries included in this report represent 4.2 billion people, which is about $61 \%$ of the world's population. The installed capacity in these countries is estimated to represent over $90 \%$ of the solar thermal market worldwide.

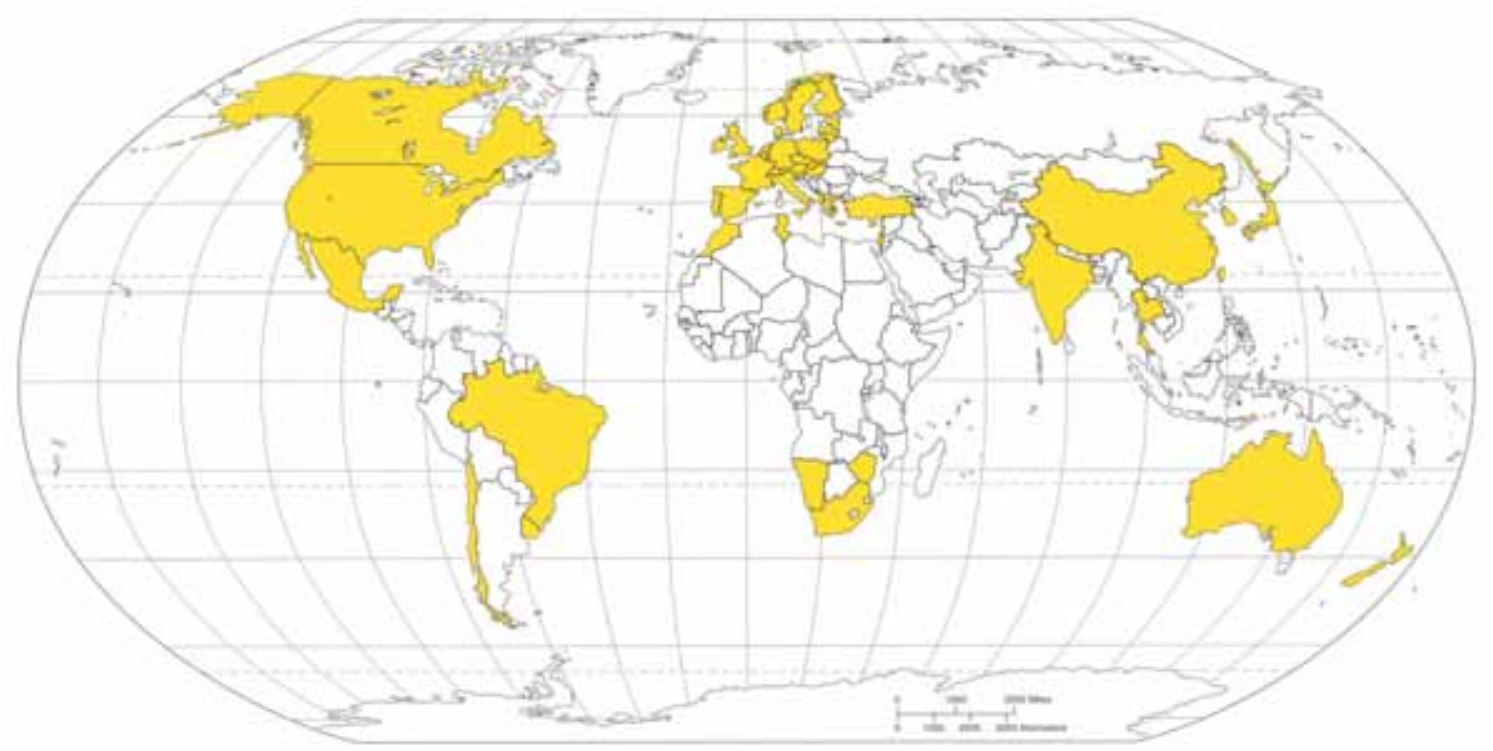

Figure 1: Countries represented in this report 


\section{Summary}

\section{Total installed capacity in operation worldwide by the end of $\mathbf{2 0 1 0}$}

By the end of 2010, an installed capacity of $195.8 \mathrm{GW}_{\text {th }}$ corresponding to a total of 279.7 million square meters ${ }^{1}$ of collector area was in operation in the 55 countries recorded in this report. These 55 countries represent 4.2 billion people, which is $61 \%$ of the world's population. The installed capacity in these countries represents more than $95 \%$ of the solar thermal market worldwide.

The vast majority of the total 2010 capacity was installed in China (117.6 GW gether accounted for $78.5 \%$ of the total installed. The remaining installed capacity was shared between the United States and Canada (16.0 GW $\mathrm{Gh}_{\text {th }}$ ), Asia, excluding China (9.4 GW $\mathrm{Gh}_{\text {th }}$ ), Australia and New Zealand (6.0 GW $\mathrm{Gh}_{\text {th }}$ ), Central and South America ( $5.5 \mathrm{GW}_{\text {th }}$ ), the MENA ${ }^{2}$ countries Israel, Jordan, Lebanon, Morocco and Tunisia ( $4.4 \mathrm{GW}_{\mathrm{th}}$ ) as well as between some Sub-Saharan African countries ( $0.8 \mathrm{GW}$ th $)$, namely Namibia, South Africa and Zimbabwe.

The leading countries in cumulated water collector capacity in operation in 2010 per 1,000 inhabitants were Cyprus (577 kW th $/ 1,000$ inhabitants); Israel (397 kW 1 th 1,000 inhabitants); Austria (388 kWth 1,000 inhabitants); Barbados (323 kWth $/ 1,000$ inhabitants), Australia (271 kW Turkey (120 kW th $/ 1,000$ inhabitants), Germany (118 kW $/$ th 1,000 inhabitants), Jordan (109 kWth $/ 1,000$ inhabitants) and Switzerland ( $93 \mathrm{~kW}$ th $/ 1,000$ inhabitants).

The breakdown of the cumulated capacity in operation in 2010 by collector type is $31.7 \%$ glazed flat-plate collectors, $56.6 \%$ evacuated tube collectors, $11.0 \%$ unglazed water collectors and $0.7 \%$ glazed and unglazed air collectors.

\section{Newly installed capacity worldwide in $\mathbf{2 0 1 0}$}

In the year 2010, a total capacity of $42.2 \mathrm{GW}_{\text {th }}$ corresponding to 60.2 million square meters of solar collectors were installed worldwide. This means an increase in new collector installations of $13.9 \%$ compared to the year 2009 .

The main markets were in China ( $34.30 \mathrm{GW}_{\text {th }}$ ) and Europe ( $3.93 \mathrm{GW}_{\mathrm{th}}$ ), which together accounted for $94.7 \%$ of the overall new collector installations in 2010. The rest of the market was shared between the United States and Canada (0.95 GW $\mathrm{th}_{\text {th }}$ ), Asia, excluding China, (0.88 GW $\mathrm{th}_{\text {th }}$ ), Central and South America (0.87 GW $\mathrm{th}_{\text {th }}$ ), Australia (0.76 $\mathrm{GW}_{\text {th }}$ ), the MENA region represented by Israel, Jordan, Lebanon, Morocco and Tunisia ( $\left.0.40 \mathrm{GW}_{\text {th }}\right)$ and the Sub-Saharan African countries Namibia, South Africa and Zimbabwe (0.08 GW $\mathrm{GW}_{\text {th }}$.

The leading countries in newly installed water collector capacity in 2010 per 1,000 inhabitants were Australia (35 kW $\mathrm{th} / 1,000$ inhabitants); Israel (30 kW $\mathrm{th} / 1,000$ inhabitants); China (26 kWth $/ 1,000$ inhabitants); Austria (24 kW $/ 1,000$ inhabitants), Cyprus (22 kW $\mathrm{th} / 1,000$ inhabitants), Turkey (15 kW $\mathrm{th}_{\mathrm{th}} / 1,000$ inhabitants), Switzerland (14 kW $\mathrm{th} / 1,000$ inhabitants), Greece (14 kWth $/ 1,000$ inhabitants), Portugal (12 $\mathrm{kW}_{\mathrm{th}} / 1,000$ inhabitants) and Jordan $(11 \mathrm{~kW}$ th $/ 1,000$ inhabitants).

The breakdown of the newly installed capacity in 2010 by collector type is $17.9 \%$ glazed flat-plate collectors, $77.8 \%$ evacuated tube collectors, $4.1 \%$ unglazed water collectors and $0.2 \%$ glazed and unglazed air collectors.

1 To compare the installed capacity of solar thermal collectors with other energy sources, solar thermal experts agreed upon a methodology to convert installed collector area into solar thermal capacity at a joint meeting of the IEA SHC Programme and major solar thermal trade associations held September 2004 in Gleisdorf, Austria. The represented associations from Austria, Canada, Germany, the Netherlands, Sweden and United States as well as the European Solar Thermal Industry Federation (ESTIF) and the IEA SHC Programme agreed to use a factor of $0.7 \mathrm{~kW}_{\mathrm{th}} / \mathrm{m} 2$ to derive the nominal capacity from the area of installed collectors.

2 Middle East and North Africa 


\section{Contribution to the energy supply and $\mathrm{CO}_{2}$ reduction}

The annual collector yield of all water-based solar thermal systems in operation by the end of 2010 in the 55 recorded countries was $162,125 \mathrm{GWh}$ ( $=583,649 \mathrm{TJ})$. This corresponds to energy savings equivalent to 17.3 million tons of oil and 53.1 million tons of $\mathrm{CO}_{2}$.

\section{Distribution of systems by system type and application}

The thermal utilization of the energy from the sun varies greatly in different regions on Earth. It can be roughly distinguished by the type of solar thermal collector used, the way of system operation (pumped solar thermal system or thermosiphon systems) and the main application the energy gained from the sun is used for (hot water preparation, space heating, industrial processes, cooling).

In China vacuum tube collectors play an important role and since China is by far the largest market with high growth rates the worldwide figures tend towards a higher share of this type of solar thermal collector as well. Unglazed water collectors account for $11 \%$ of the cumulated water collectors installed worldwide and tends to decrease.

Worldwide about three quarters of all solar thermal systems installed are operated by means of the thermosiphon principle and the rest are pumped solar heating systems. Similar to the distribution by type of solar thermal collector, the Chinese market influences the overall figures most and in $201089 \%$ of the newly installed systems were estimated to be thermosiphon systems while pumped system only accounted for $11 \%$.

The calculated number of different types of solar thermal systems in operation exceeded 53 million by the end of 2010. Hereof, an estimated $85 \%$ were used for domestic hot water preparation in single family houses and $10 \%$ were attached to larger domestic hot water consumers such as multifamily houses, hotels, hospitals, schools, homes for elderly people, etc. The remaining $5 \%$ of the worldwide installed capacity supplied heat for both domestic hot water and space heating (solar combi systems) and for other applications, such as solar supported district heating networks, industrial processes and solar air conditioning applications.

By contrast, for newly installed systems the trend was towards more sophisticated applications with a worldwide share of $10 \%$ for solar combi systems and other applications than domestic hot water preparation. In several well-established markets in Europe (e.g., Germany, Spain, Austria, Switzerland and France) solar domestic hot water preparation accounted for less than half of the total market in 2010 whereas the market penetration of solar combi systems, solar supported district heating networks, industrial applications and solar air conditioning systems increased.

\section{Employment}

Based on data collected from detailed country reports, the number of jobs in the fields of production, installation and maintenance of solar thermal systems is estimated to be 375,000 worldwide in 2011.

\section{Preview 2011}

The estimated total capacity of solar thermal collectors in operation worldwide by the end of 2010 is $245 \mathrm{GW}_{\text {th }}$ respectively 350 million square meters of collector area. 


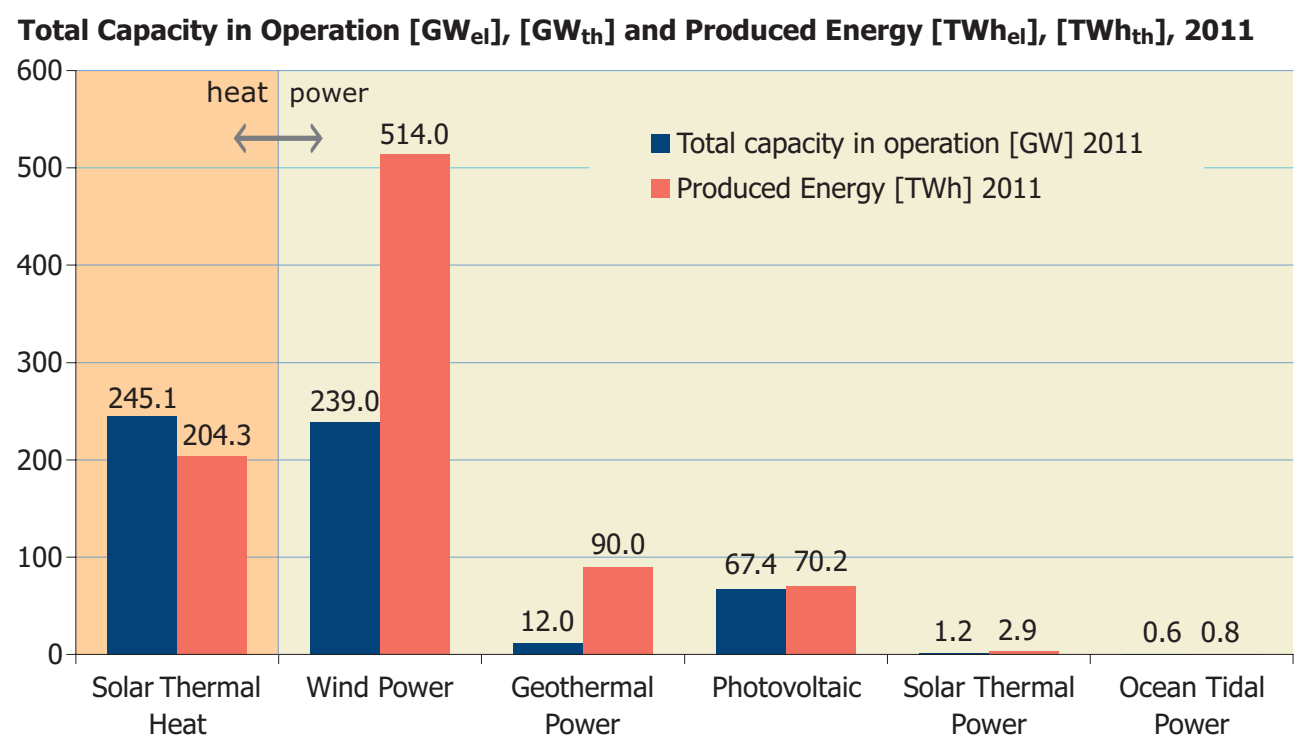

Figure 2: Total capacity in operation [ $\left.\mathrm{GW}_{\mathrm{el}}\right]$, [GW $\mathrm{th}$ ] 2011 and annual energy generated [TWh $\mathrm{Tl}_{\mathrm{el}}$, [TWh $\left.\mathrm{TWh}_{\mathrm{th}}\right]$. Sources: EPIA, EGEC, Earth Policy Institute, IEA SHC 2011, WWEA

Compared with other forms of renewable energy, solar heating's contribution in meeting global energy demand is, besides the traditional renewable energies like biomass and hydropower, second only to wind power.

In 2011, the cumulated wind power capacity installed was almost as high as the total installed solar thermal capacity in operation, whereas, in the year 2005 the installed wind power capacity was half compared to solar thermal. Another growing market in 2011 was photovoltaics. In 2005 peak photovoltaic power installed was about 1/30 of the total solar thermal capacity installed; in 2011 photovoltaic was heading towards 1/3. 
This report aims to give the actual collector area in operation and not the cumulated collector area that has ever been installed in a country. To determine the collector area (and respective capacity) in operation, either official country reports on the lifetime base were used or, if such reports were not available, a 25-year lifetime for a system was calculated. The collector area in operation was then calculated using a linear equation.

With respect to the methodology of the Chinese Solar Thermal Industry Federation (CSTIF) the operation lifetime is considered to be 10 years in China.

The analysis further aims to distinguish between different types of solar thermal collectors such as unglazed water collectors, glazed water collectors including flat plate collectors (FPC) and evacuated tube collectors (ETC) as well as unglazed and glazed air collectors.

\subsection{General market overview of the total installed capacity in operation}

By the end of 2010, an installed capacity of $195.8 \mathrm{GW}_{\text {th }}$ corresponding to a total of 279.7 million square meters of collector area was in operation in the 55 countries recorded in this report. These 55 countries represent 4.2 billion people, which is $61 \%$ of the world's population. The installed capacity in these countries represents more than $90 \%$ of the solar thermal market worldwide.

The vast majority of the total capacity in operation was installed in China (117.6 $\mathrm{GW}_{\mathrm{th}}$ ) and Europe (36.0 $\mathrm{GW}_{\mathrm{th}}$ ), which together accounted for $78.5 \%$ of total installed. The remaining installed capacity was shared between the United States and Canada (16.0 GW $\mathrm{GW}_{\text {th }}$ ), Asia excluding China (9.4 GW $\mathrm{GW}_{\mathrm{th}}$ ), Australia and New Zealand (6.0 GW th), Central and South America (5.5 GW th), the MENA ${ }^{3}$ countries Israel, Jordan, Lebanon, Morocco and Tunisia $\left(4.4 \mathrm{GW}_{\mathrm{th}}\right)$ as well as between some Sub-Saharan African countries $\left(0.8 \mathrm{GW}_{\mathrm{th}}\right)$, namely Namibia, South Africa and Zimbabwe.
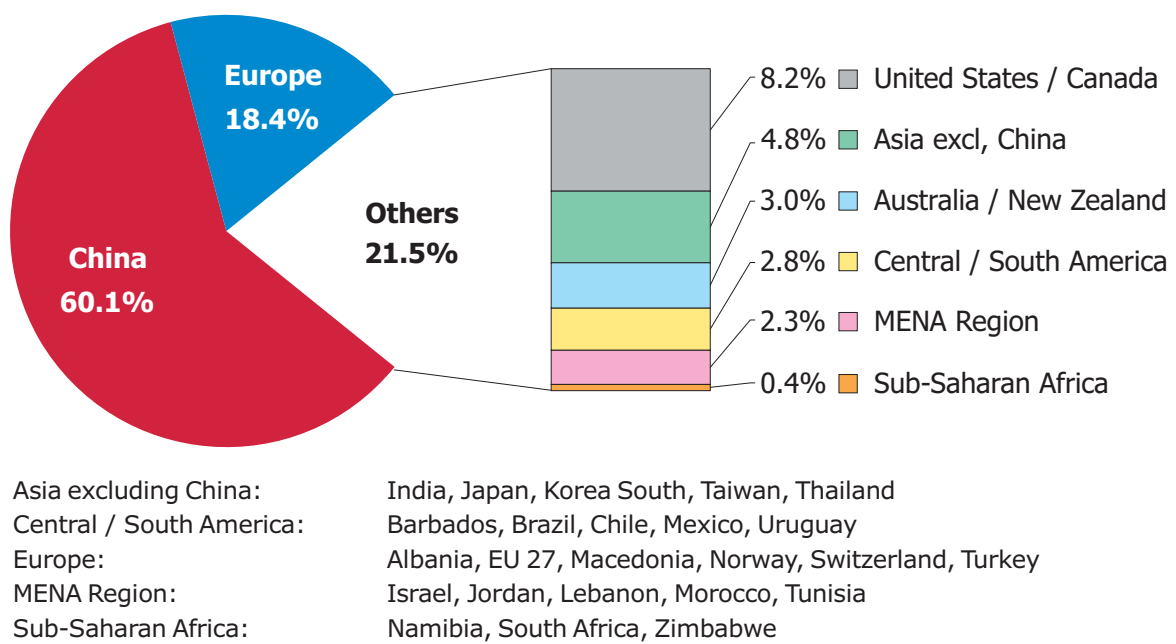

India, Japan, Korea South, Taiwan, Thailand

Barbados, Brazil, Chile, Mexico, Uruguay

Albania, EU 27, Macedonia, Norway, Switzerland, Turkey

Israel, Jordan, Lebanon, Morocco, Tunisia

Namibia, South Africa, Zimbabwe

Figure 3: Share of the total installed capacity in operation (glazed and unglazed water and air collectors) by economic regions at the end of 2010

As shown in Table 1 and Table 2, the total capacity is divided into $62.1 \mathrm{GW}$ th flat plate collectors, referred to as FPC, (88.8 million square meters) and $111 \mathrm{GW}_{\text {th }}$ evacuated tube collectors, referred to as ETC, (158.5 million square meters), $21.5 \mathrm{GW}_{\text {th }}$ unglazed water collectors (30.7 million square meters) and $1.3 \mathrm{GW}_{\text {th }}$ glazed and unglazed air collectors (1.8 million square meters). 


\begin{tabular}{|c|c|c|c|c|c|c|}
\hline \multirow{2}{*}{ Country } & \multicolumn{3}{|c|}{ Water Collectors*** } & \multicolumn{2}{|c|}{ Air Collectors*** } & \multirow{2}{*}{ TOTAL $\left[\mathrm{MW}_{\mathrm{th}}\right]$} \\
\hline & unglazed & FPC & ETC & unglazed & glazed & \\
\hline Albania & & 54.0 & 0.4 & & & 54.4 \\
\hline Australia & $3,780.0$ & $1,964.1$ & 76.8 & & & $5,820.9$ \\
\hline Austria & 419.6 & $2,724.6$ & 46.5 & 0.5 & & $3,191.3$ \\
\hline Barbados* & & 92.2 & & & & 92.2 \\
\hline Belgium & 32.8 & 198.7 & 22.9 & & & 254.5 \\
\hline Brazil & 894.0 & $3,384.0$ & & & & $4,278.0$ \\
\hline Bulgaria & & 32.3 & 0.5 & & & 32.7 \\
\hline Canada & 459.5 & 33.4 & 12.9 & 214.6 & 3.2 & 723.7 \\
\hline Chile & & 19.7 & & & & 19.7 \\
\hline China & & $9,448.3$ & $108,151.7$ & & & $117,600.0$ \\
\hline Cyprus & 2.4 & 626.9 & 6.9 & & & 636.1 \\
\hline Czech Republic & 105.0 & 174.8 & 40.8 & & & 320.6 \\
\hline Denmark & 14.4 & 365.3 & 5.7 & 2.3 & 12.6 & 400.2 \\
\hline Estonia & & 1.4 & 0.6 & & & 2.0 \\
\hline Finland & 8.2 & 21.1 & 3.0 & & & 32.4 \\
\hline France incl. DOM & 62.4 & $1,490.9$ & 44.7 & & & $1,598.0$ \\
\hline Germany & 445.9 & $8,233.2$ & 925.0 & & 23.5 & $9,627.6$ \\
\hline Greece & & $2,849.5$ & 11.4 & & & $2,860.9$ \\
\hline Hungary & 5.7 & 83.8 & 21.1 & 0.6 & 0.2 & 111.3 \\
\hline India & & $2,413.2$ & 365.8 & & 11.4 & $2,790.4$ \\
\hline Ireland & 0.3 & 71.8 & 34.0 & & & 106.1 \\
\hline Israel & 20.9 & $2,896.5$ & & 0.3 & & $2,917.8$ \\
\hline Italy & 30.6 & $1,562.5$ & 220.8 & & & $1,813.9$ \\
\hline Japan & & $3,645.5$ & 65.2 & & 339.0 & $4,049.6$ \\
\hline Jordan & 4.2 & 538.3 & 153.0 & & & 695.5 \\
\hline Korea, South & & $1,096.4$ & & & & $1,096.4$ \\
\hline Latvia & & 4.9 & 0.2 & & & 5.1 \\
\hline Lebanon** & & 243.8 & & & & 243.8 \\
\hline Lithuania & & 3.0 & 0.2 & & & 3.2 \\
\hline Luxembourg & & 19.6 & 2.0 & & & 21.6 \\
\hline Macedonia* & & 17.5 & 0.5 & & 0.003 & 18.0 \\
\hline Malta & & 22.5 & 7.9 & & & 30.4 \\
\hline Mexico & 463.5 & 500.1 & 108.8 & & 5.6 & $1,078.0$ \\
\hline Morocco** & & 238.9 & & & & 238.9 \\
\hline Namibia & & 14.5 & 0.9 & & & 15.4 \\
\hline Netherlands & 277.5 & 283.4 & 7.0 & & & 567.9 \\
\hline New Zealand* & 4.9 & 100.1 & 6.8 & & & 111.8 \\
\hline Norway & 1.4 & 10.1 & 0.7 & & 0.7 & 13.0 \\
\hline Poland & & 356.9 & 102.2 & & & 459.1 \\
\hline Portugal & 1.7 & 512.2 & 13.8 & & & 527.7 \\
\hline Romania & & 65.8 & 11.2 & & & 77.0 \\
\hline Slovakia & & 84.5 & 10.5 & & & 95.0 \\
\hline Slovenia & & 105.5 & 9.1 & & & 114.6 \\
\hline South Africa & 562.6 & 231.7 & 20.1 & & & 814.4 \\
\hline Spain & 85.4 & $1,540.4$ & 96.3 & & & $1,722.0$ \\
\hline Sweden & 98.0 & 171.5 & 39.9 & & & 309.4 \\
\hline Switzerland & 149.0 & 521.6 & 35.1 & 606.9 & & $1,312.6$ \\
\hline Taiwan & 0.1 & $1,379.2$ & 52.8 & & & $1,432.1$ \\
\hline Thailand* & & 64.0 & & & & 64.0 \\
\hline Tunisia & & 319.3 & 23.5 & & & 342.8 \\
\hline Turkey & & 9,323.1 & & & & $9,323.1$ \\
\hline United Kingdom & & 307.8 & 87.5 & & & 395.3 \\
\hline United States & $13,552.8$ & $1,647.5$ & 64.9 & & 51.5 & $15,316.7$ \\
\hline Uruquay* & & 8.5 & & & & 8.5 \\
\hline Zimbabwe & & 12.6 & 0.2 & & & 12.7 \\
\hline TOTAL & $21,482.7$ & $62,132.6$ & $110,911.7$ & 825.2 & 447.8 & $195,800.0$ \\
\hline
\end{tabular}

Table 1: Total capacity in operation by the end of 2010 [MW $\left.\mathrm{H}_{\text {th }}\right]$ 


\begin{tabular}{|c|c|c|c|c|c|c|}
\hline \multirow{2}{*}{ Country } & \multicolumn{3}{|c|}{ Water Collectors $* * *$} & \multicolumn{2}{|c|}{ Air Collectors*** } & \multirow{2}{*}{ TOTAL $\left[\mathrm{m}^{2}\right]$} \\
\hline & unglazed & FPC & ETC & unglazed & glazed & \\
\hline Albania & & 77,185 & 548 & & & 77,733 \\
\hline Australia & $5,400,000$ & $2,805,920$ & 109,643 & & & $8,315,563$ \\
\hline Austria & 599,491 & $3,892,305$ & 66,482 & 728 & & $4,559,006$ \\
\hline Barbados* & & 131,690 & & & & 131,690 \\
\hline Belgium & 46,875 & 283,926 & 32,708 & & & 363,509 \\
\hline Brazil & $1,277,128$ & $4,834,349$ & & & & $6,111,477$ \\
\hline Bulgaria & & 46,086 & 650 & & & 46,736 \\
\hline Canada & 656,485 & 47,758 & 18,456 & 306,549 & 4,616 & $1,033,864$ \\
\hline Chile & & 28,159 & & & & 28,159 \\
\hline China & & $13,497,591$ & $154,502,409$ & & & $168,000,000$ \\
\hline Cyprus & 3,363 & 895,503 & 9,918 & & & 908,784 \\
\hline Czech Republic & 150,000 & 249,664 & 58,275 & & & 457,939 \\
\hline Denmark & 20,515 & 521,810 & 8,084 & 3,264 & 18,000 & 571,673 \\
\hline Estonia & & 2,051 & 790 & & & 2,841 \\
\hline Finland & 11,779 & 30,118 & 4,342 & & & 46,240 \\
\hline France incl. DOM & 89,181 & $2,129,796$ & 63,900 & & & $2,282,877$ \\
\hline Germany & 637,010 & $11,761,731$ & $1,321,423$ & & 33,600 & $13,753,764$ \\
\hline Greece & & $4,070,700$ & 16,300 & & & $4,087,000$ \\
\hline Hungary & 8,088 & 119,711 & 30,103 & 800 & 350 & 159,052 \\
\hline India & & $3,447,384$ & 522,616 & & 16,320 & $3,986,320$ \\
\hline Ireland & 421 & 102,537 & 48,640 & & & 151,598 \\
\hline Israel & 29,900 & $4,137,895$ & & 450 & & $4,168,245$ \\
\hline Italy & 43,766 & $2,232,097$ & 315,481 & & & $2,591,344$ \\
\hline Japan & & $5,207,908$ & 93,075 & & 484,226 & $5,785,209$ \\
\hline Jordan & 5,940 & 768,992 & 218,570 & & & 993,502 \\
\hline Korea, South & & $1,566,319$ & & & & $1,566,319$ \\
\hline Latvia & & 7,004 & 240 & & & 7,244 \\
\hline Lebanon** & & 348,312 & & & & 348,312 \\
\hline Lithuania & & 4,218 & 300 & & & 4,518 \\
\hline Luxembourg & & 27,982 & 2,818 & & & 30,800 \\
\hline Macedonia* & & 25,020 & 724 & & 4 & 25,748 \\
\hline Malta & & 32,167 & 11,302 & & & 43,469 \\
\hline Mexico & 662,092 & 714,432 & 155,430 & & 7,983 & $1,539,937$ \\
\hline Morocco** & & 341,260 & & & & 341,260 \\
\hline Namibia & & 20,699 & 1,307 & & & 22,006 \\
\hline Netherlands & 396,410 & 404,821 & 10,000 & & & 811,231 \\
\hline New Zealand* & 7,025 & 142,975 & 9,644 & & & 159,645 \\
\hline Norway & 2,011 & 14,406 & 1,054 & & 1,062 & 18,533 \\
\hline Poland & & 509,800 & 146,000 & & & 655,800 \\
\hline Portugal & 2,435 & 731,693 & 19,665 & & & 753,793 \\
\hline Romania & & 93,996 & 16,000 & & & 109,996 \\
\hline Slovakia & & 120,692 & 15,055 & & & 135,746 \\
\hline Slovenia & & 150,656 & 13,042 & & & 163,698 \\
\hline South Africa & 803,678 & 331,010 & 28,672 & & & $1,163,360$ \\
\hline Spain & 122,000 & $2,200,500$ & 137,500 & & & $2,460,000$ \\
\hline Sweden & 140,000 & 245,000 & 57,000 & & & 442,000 \\
\hline Switzerland & 212,850 & 745,150 & 50,110 & 867,000 & & $1,875,110$ \\
\hline Taiwan & 85 & $1,970,300$ & 75,461 & & & $2,045,847$ \\
\hline Thailand* & & 91,392 & & & & 91,392 \\
\hline Tunisia & & 456,200 & 33,500 & & & 489,700 \\
\hline Turkey & & $13,318,659$ & & & & $13,318,659$ \\
\hline United Kingdom & & 439,738 & 125,045 & & & 564,783 \\
\hline United States & $19,361,098$ & $2,353,565$ & 92,777 & & 73,509 & $21,880,949$ \\
\hline Uruguay* & & 12,096 & & & & 12,096 \\
\hline Zimbabwe & & 17,959 & 237 & & & 18,196 \\
\hline TOTAL 2010 & $30,689,627$ & $88,760,887$ & $158,445,297$ & $1,178,791$ & 639,671 & $279,714,273$ \\
\hline
\end{tabular}

Table 2: Total installed collector area in operation by the end of 2010 [ $\mathrm{m}^{2}$ ] 
The distribution of the worldwide capacity in operation by the different types of solar collectors is shown in Figure 4.

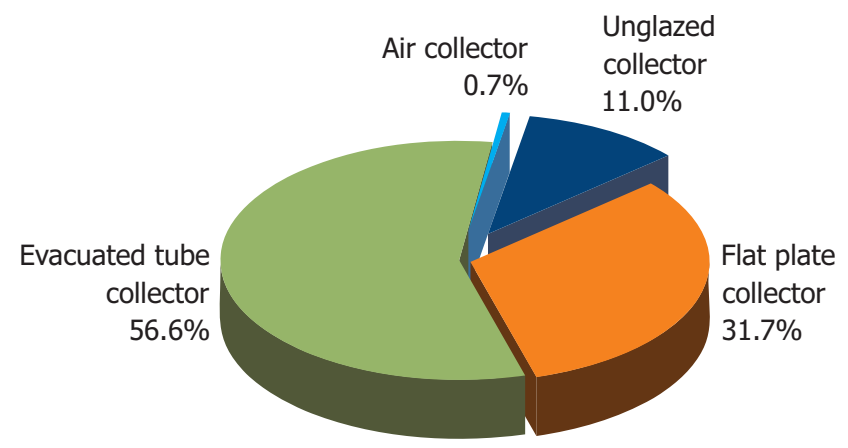

Figure 4: Distribution of the total installed capacity in operation by collector type in 2010

Figure 5 depicts the distribution of unglazed and glazed water collectors for the 10 leading countries by the end of 2010.

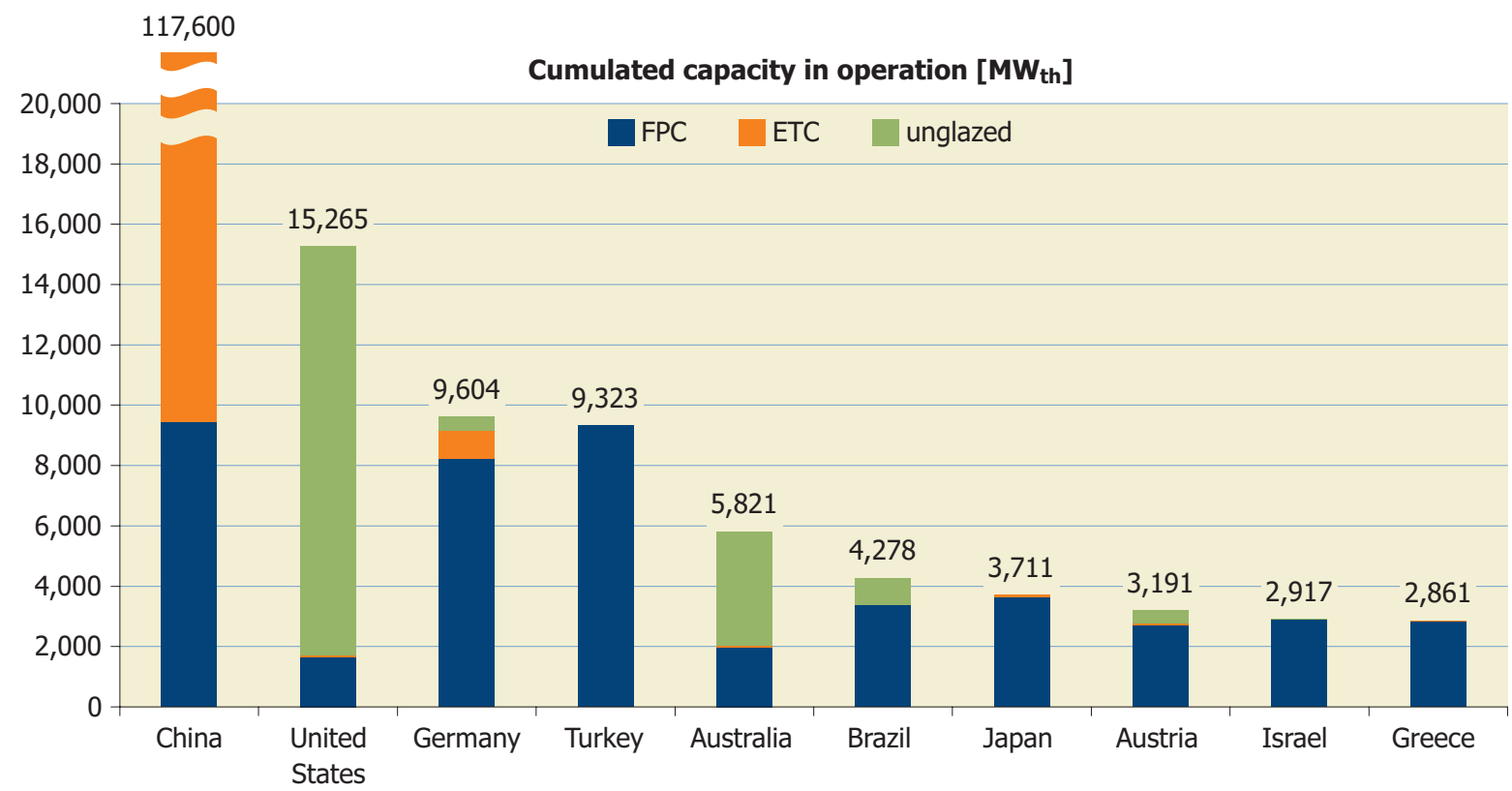

Figure 5: Total installed capacity of unglazed and glazed water collectors in operation in the 10 leading countries by the end of 2010

China, as the world leader in total capacity, is focusing very much on evacuated tube collectors, whereas the United States is holding second position due to its high installation of unglazed water collectors.

Only in Australia and to some extend in Brazil do unglazed water collectors also play an important role. The rest of the "Top 10 countries" are clearly focusing on flat plate collector technology. With the dominance of the evacuated tube market in China, it is remarkable that this country is also the world leader in terms of total installed flat plate collectors (9.5 GW $\mathrm{GW}_{\text {th }}$.

In terms of total installed capacity of glazed water collectors in operation per 1,000 inhabitants, there was a continued dominance by 5 countries (Cyprus, Israel, Austria, Barbados and Greece) but China entered the Top 10 for the first time, passing Malta (Figure 7). 


\subsection{Total capacity of glazed water collectors in operation}

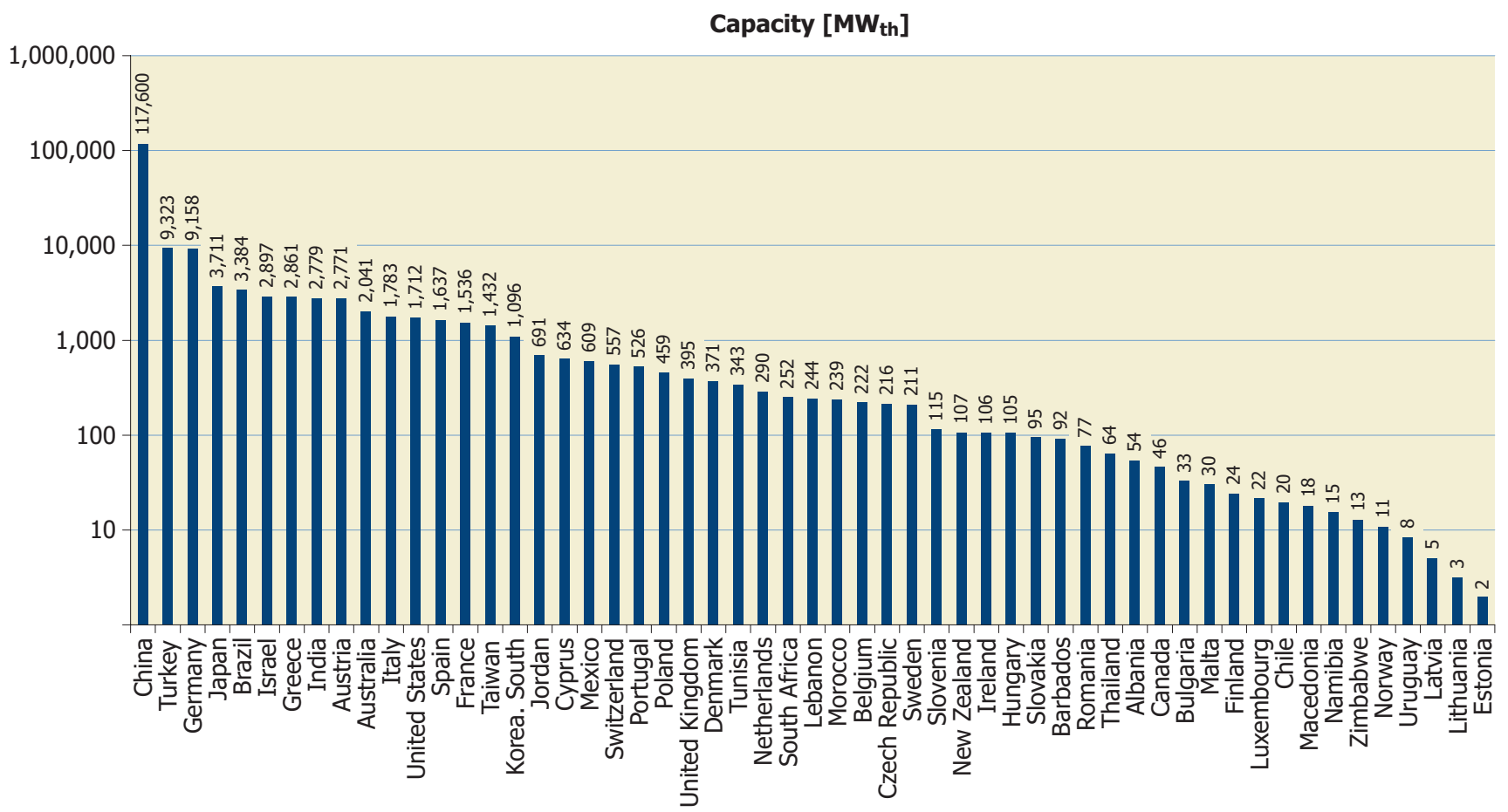

Figure 6: Total capacity of glazed flat plate and evacuated tube collectors in operation by the end of 2010

(note: logarithmic scale of $y$-axis)

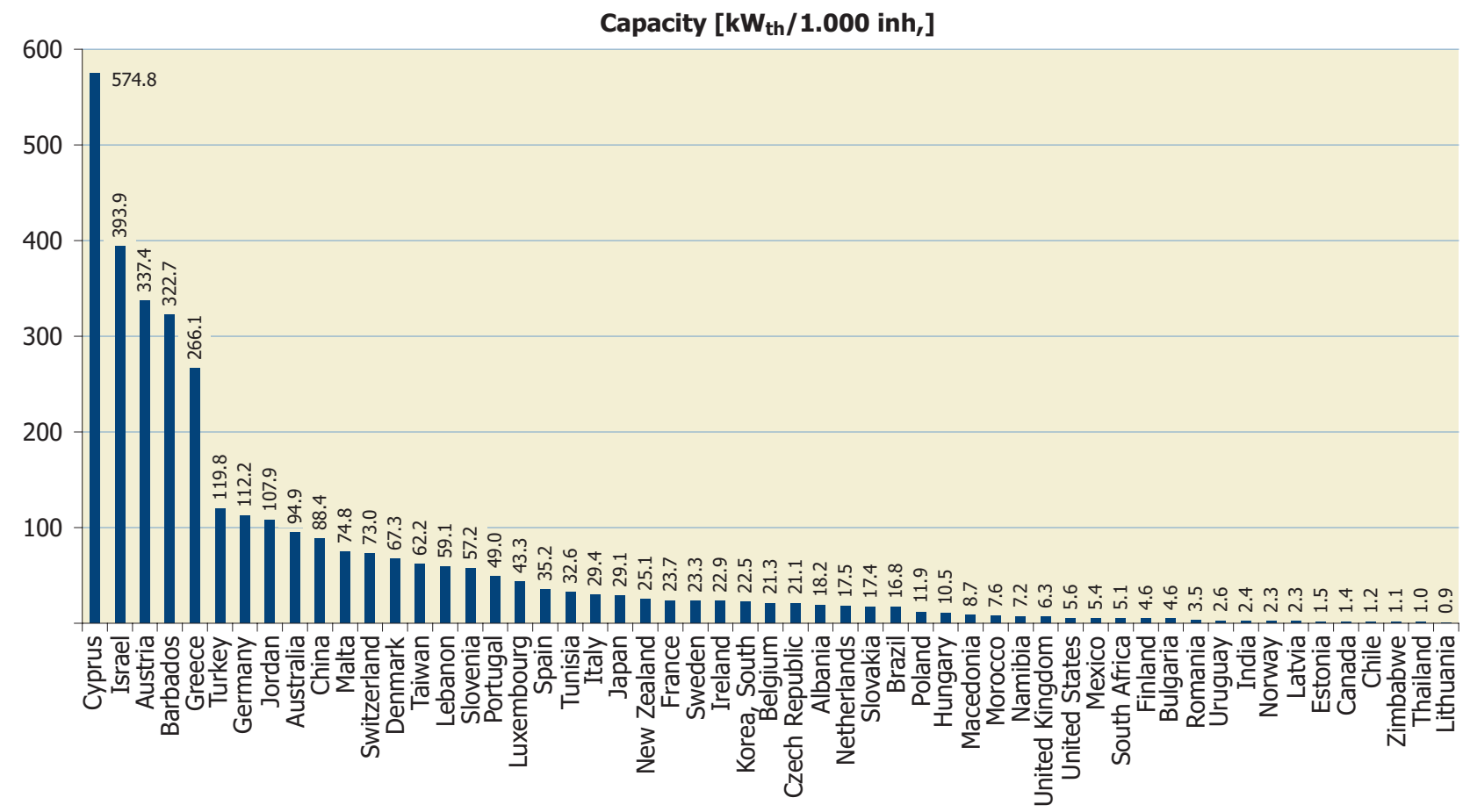

Figure 7: Total capacity of glazed flat plate and evacuated tube collectors in operation in $\mathrm{kW}_{\text {th }}$ per 1,000 inhabitants by the end of 2010 


\subsection{Total capacity of glazed water collectors in operation by economic region}

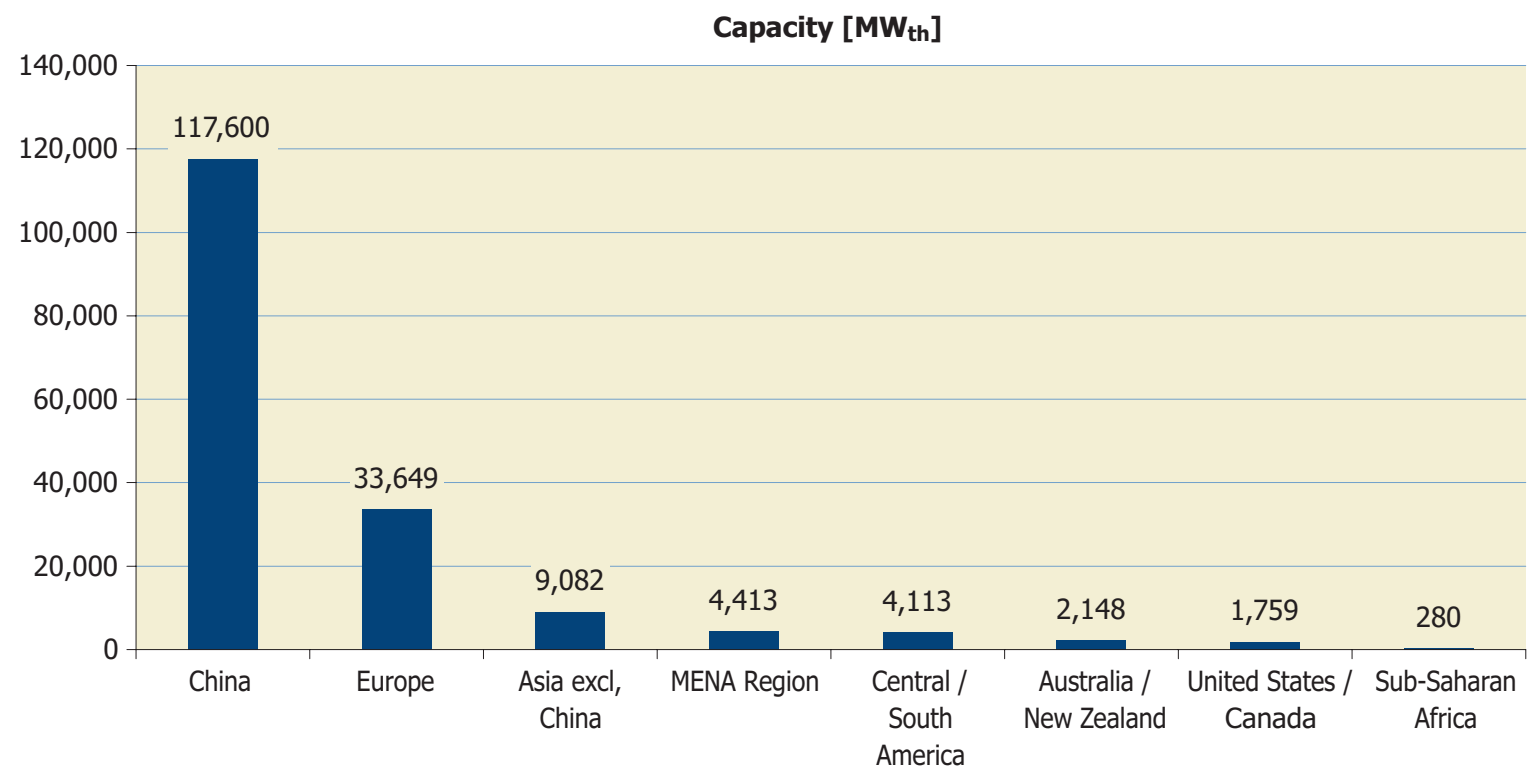

Figure 8: Total capacity of glazed flat plate and evacuated tube collectors in operation by economic region at the end of 2010

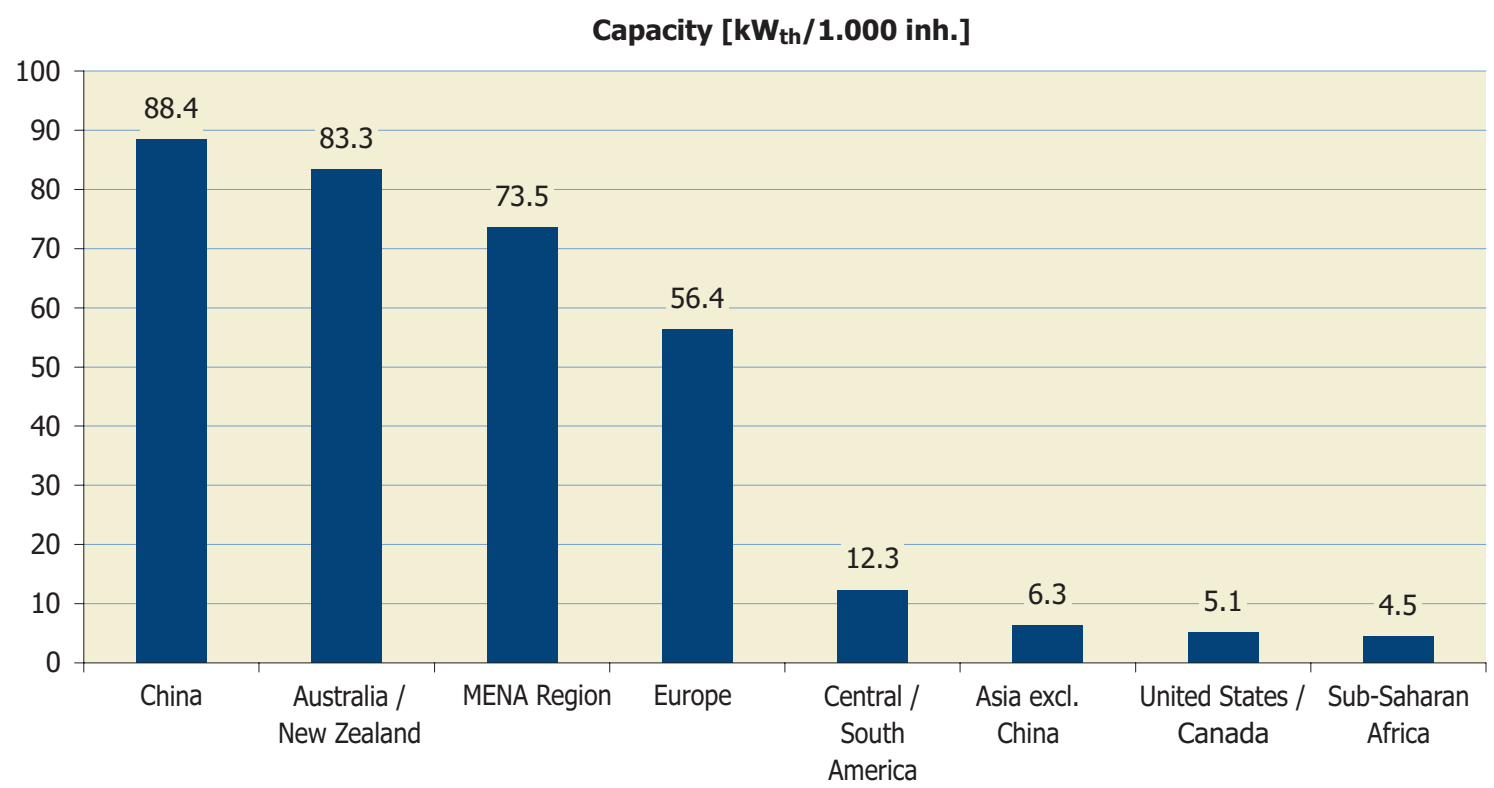

Figure 9: Total capacity of glazed flat plate and evacuated tube collectors in operation by economic region and in $\mathrm{kW}_{\text {th }}$ per 1,000 inhabitants by the end of 2010

Asia excluding China: Central / South America: Europe:

MENA Region:

Sub-Saharan Africa:
India, Japan, Korea South, Taiwan, Thailand Barbados, Brazil, Chile, Mexico, Uruguay

Albania, EU 27, Macedonia, Norway, Switzerland, Turkey

Israel, Jordan, Lebanon, Morocco, Tunisia Namibia, South Africa, Zimbabwe 


\subsection{Total capacity of unglazed water collectors in operation}

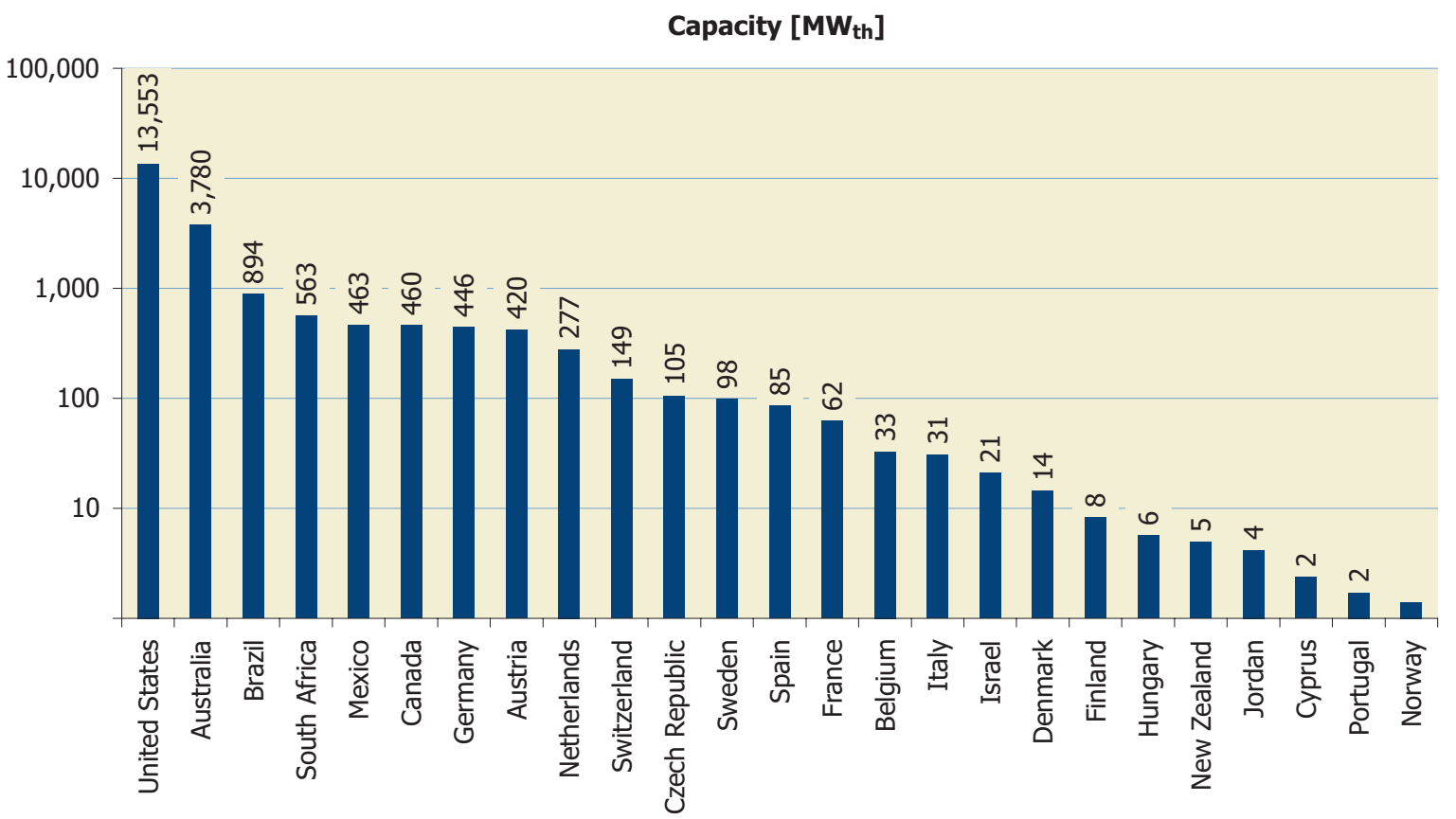

Figure 10: Total capacity of unglazed water collectors in operation by the end of 2010

(note: logarithmic scale of $y$-axis)

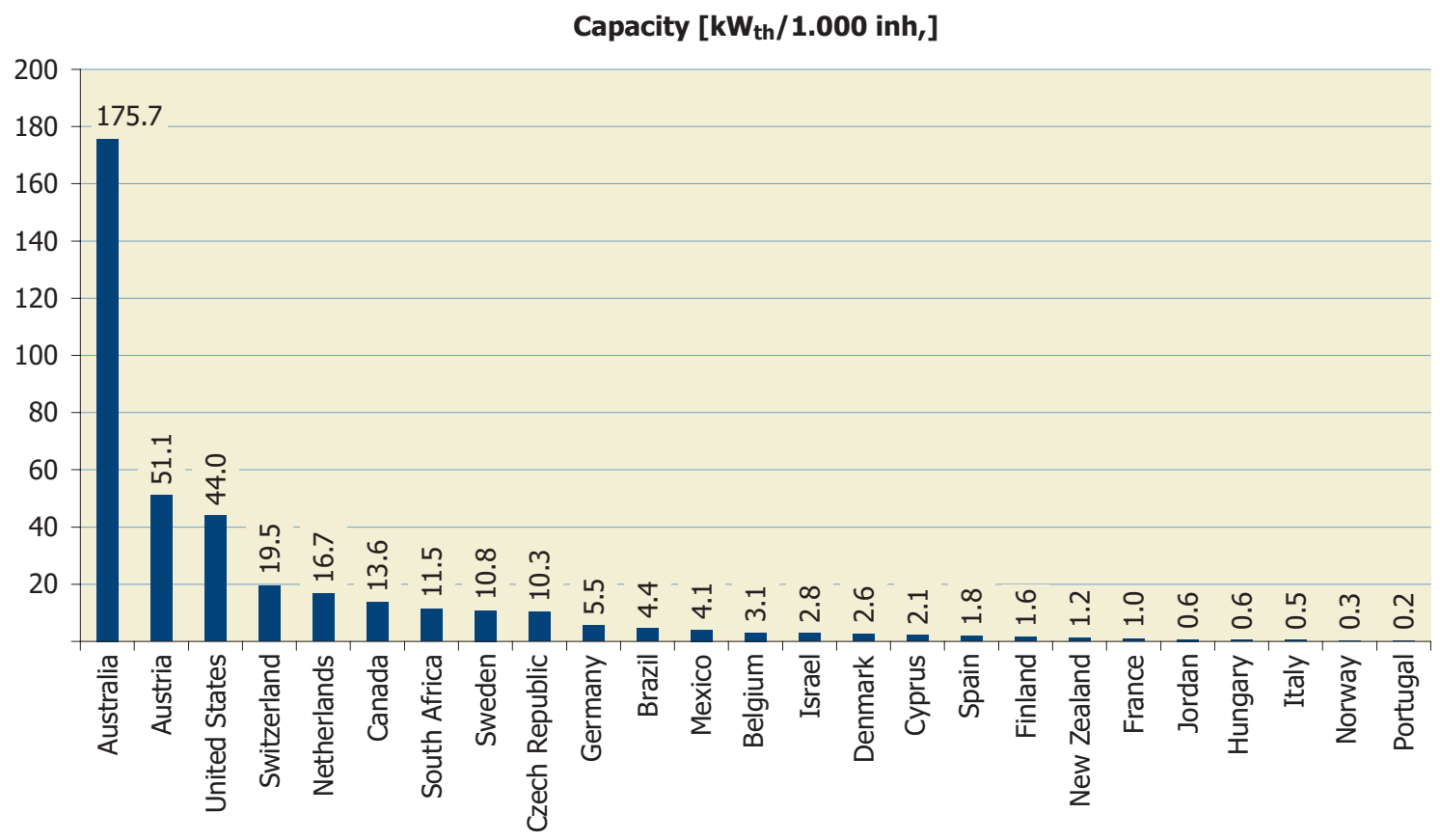

Figure 11: Total capacity of unglazed water collectors in operation in $\mathrm{kW}_{\text {th }}$ per 1,000 inhabitants by the end of 2010 


\subsection{Total capacity of unglazed water collectors in operation by economic region}

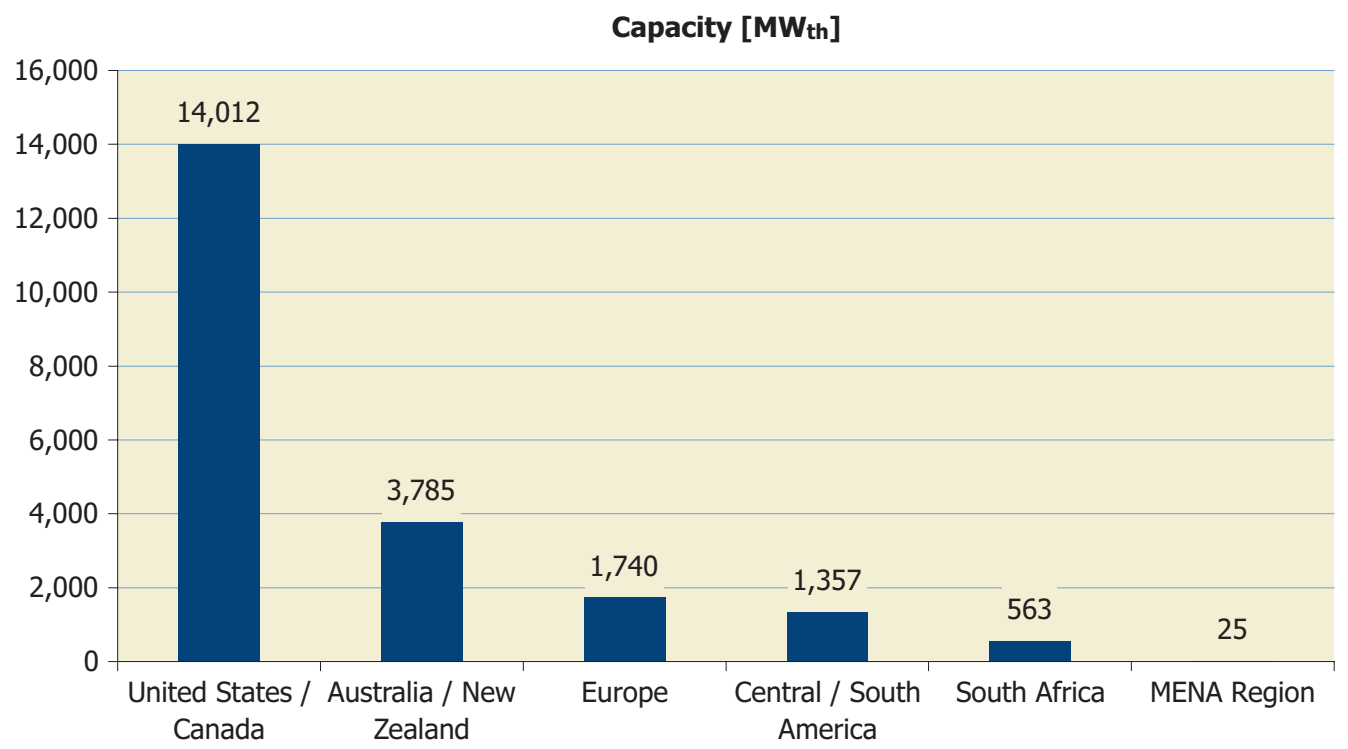

Figure 12: Total capacity of unglazed collectors in operation by economic region by the end of 2010

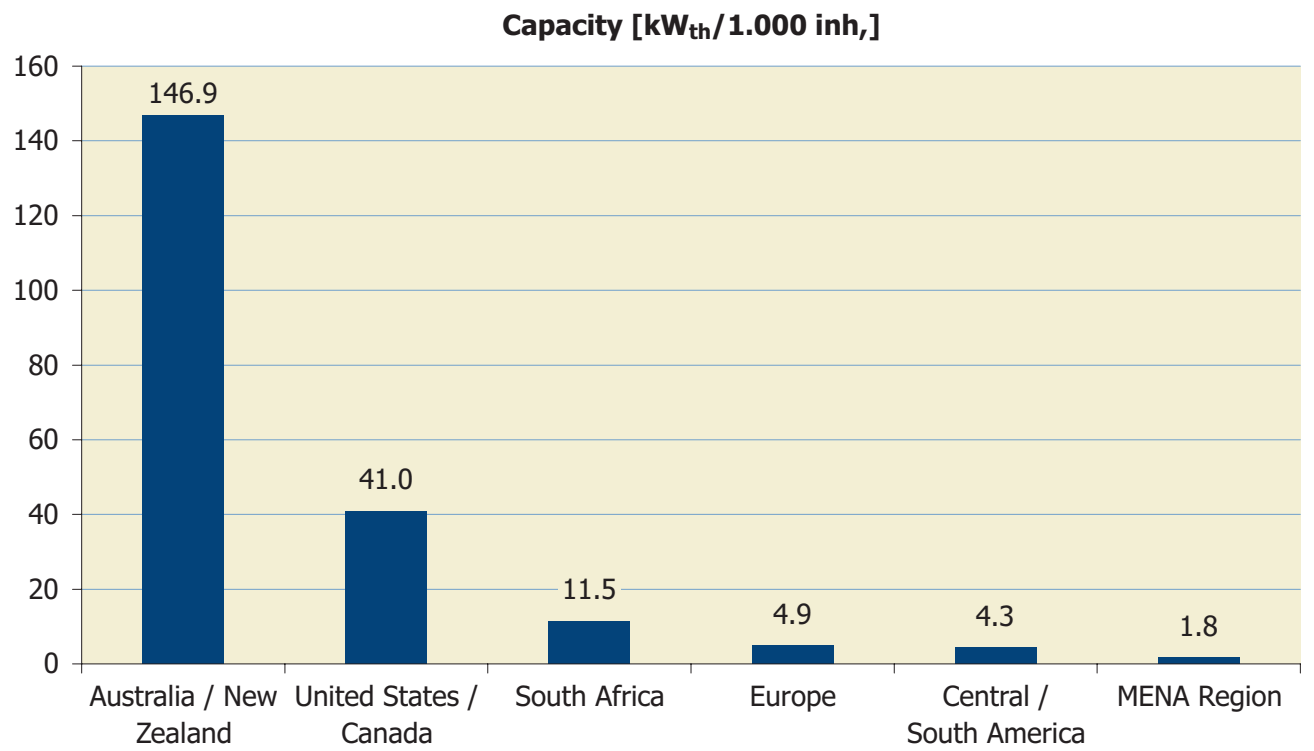

Figure 13: Total capacity of unglazed collectors in operation by economic region and in $\mathrm{kW}_{\text {th }}$ per 1,000 inhabitants by the end of 2010

Central / South America: Europe: MENA Region:
Brazil, Mexico

EU 17, Norway, Switzerland Israel, Jordan 


\section{Newly installed capacity in 2010 and market development}

In the year 2010 a total capacity of $42.2 \mathrm{GW}_{\text {th }}$, corresponding to 60.2 million square meters of solar collectors, was installed worldwide. This means an increase in new collector installations of $13.9 \%$ compared to the year 20094 .

The highest growth rates in the context of economic regions was in Asia with India and China leading the way. Whereas China has been the market leader in terms of quantities installed for more than a decade, India is becoming an important player with a fast growing market. By contrast, the mature European market has faced a significant market decrease for the second year in a row. In the period 2008/2009 the market dropped by $7.8 \%$ and 2009/2010 this trend continued with a decrease of $7.5 \%$.

The United States and Canada recovered well in 2009/2010 from a downfall in the former period while in Australia the opposite occurred where the market grew almost $28 \%$ in 2008/2009 and in 2009/2010 has experienced a decrease of $5.4 \%$, which is comparable to the decrease in the European market.

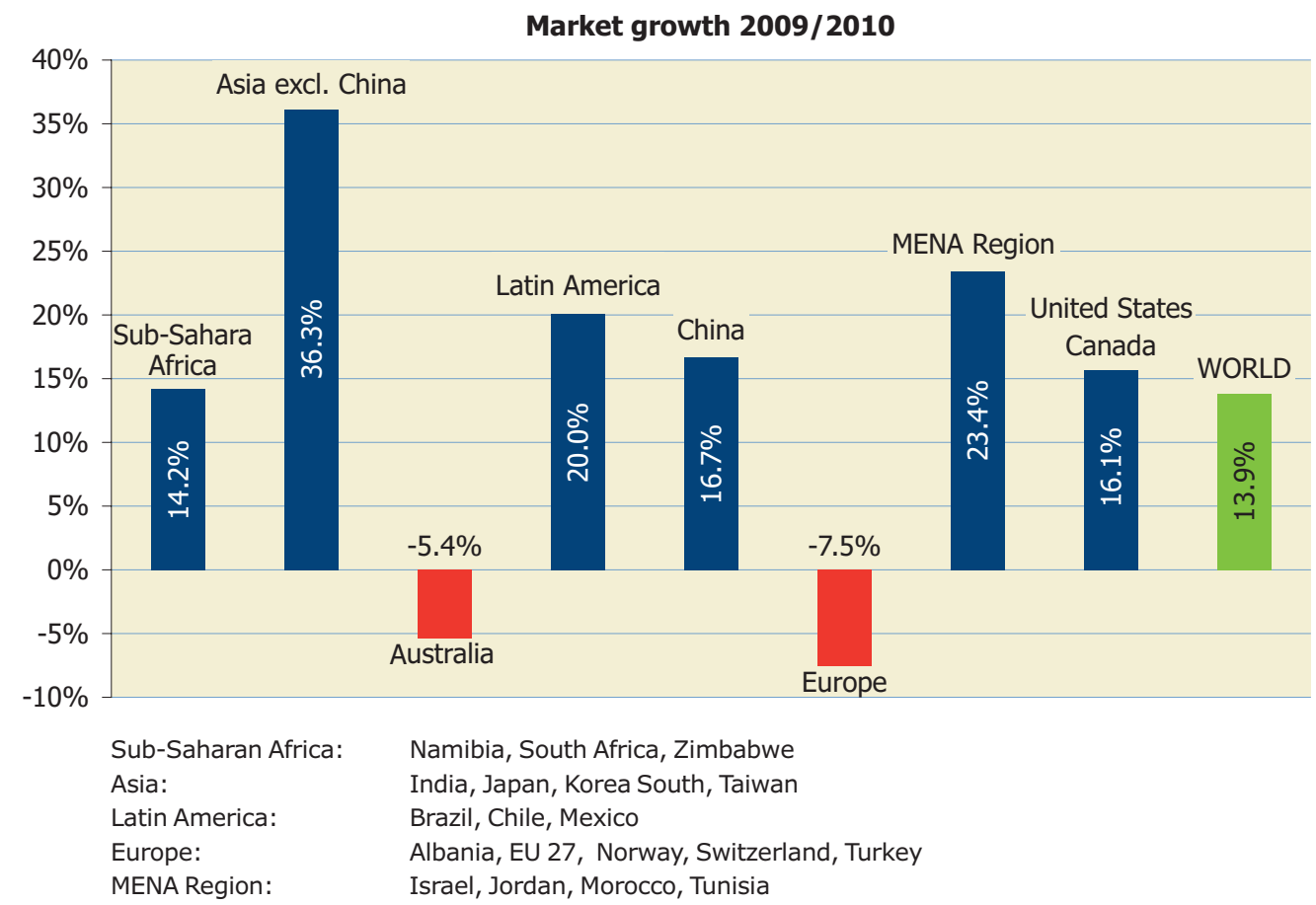

Figure 14: Market development of the newly installed capacity between 2009 and 2010 by economic region 


\subsection{General market overview of newly installed capacity}

The main markets were in China ( $34.30 \mathrm{GW}_{\text {th }}$ ) and Europe (3.93 $\left.\mathrm{GW}_{\mathrm{th}}\right)$, which together account for $94.7 \%$ of the overall new collector installations in 2010. The rest of the market is shared between the United States and Canada (0.95 GW $\mathrm{GW}_{\text {th }}$, Asia excluding China (0.88 GW $\mathrm{GW}_{\text {th }}$, Latin America $\left(0.87 \mathrm{GW}_{\text {th }}\right)$, Australia $\left(0.76 \mathrm{GW}_{\text {th }}\right)$, the MENA region represented by Israel, Jordan, Lebanon, Morocco and Tunisia $\left(0.40 \mathrm{GW}_{\text {th }}\right)$ and the Sub-Saharan African countries Namibia, South Africa and Zimbabwe (0.08 GW $\mathrm{Gth}_{\text {th }}$.

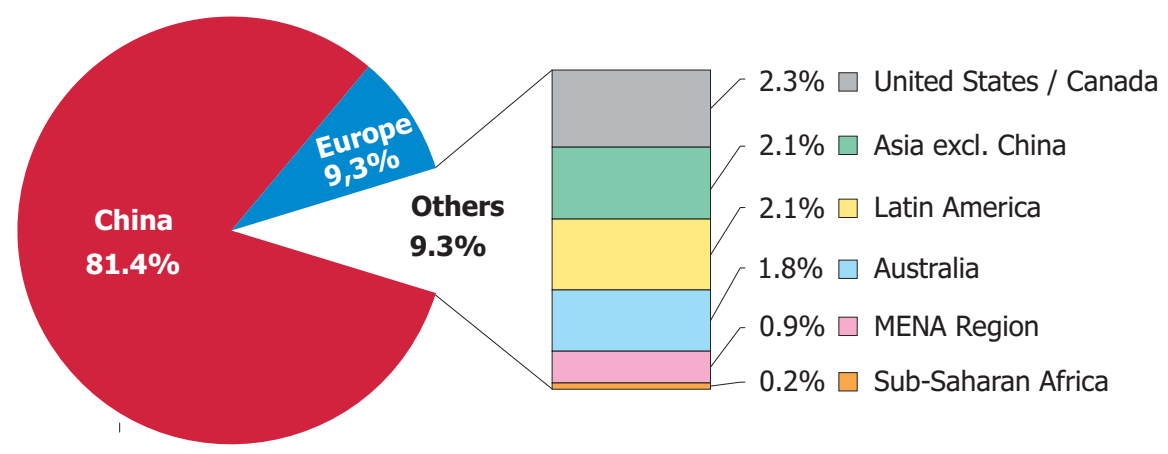

Sub-Saharan Africa:
Asia:
Latin America:
Europe:
MENA Region:

Namibia, South Africa, Zimbabwe India, Japan, Korea South, Taiwan Brazil, Chile, Mexico

Albania, EU 27, Norway, Switzerland, Turkey Israel, Jordan, Morocco, Tunisia

Figure 15: Share of the newly installed capacity (glazed and unglazed water and air collectors) by economic regions in 2010

The total capacity is divided into $7.56 \mathrm{GW}_{\text {th }}$ glazed flat plate collectors, referred to as FPC (10.80 million square meters), $32.79 \mathrm{GW}_{\text {th }}$ evacuated tube collectors, referred to as ETC (46.84 million square meters), $1.73 \mathrm{GW}_{\text {th }}$ unglazed water collectors ( 2.47 million square meters) and $0.08 \mathrm{GW}_{\text {th }}$ glazed and unglazed air collectors ( 0.12 million square meters). 


\begin{tabular}{|c|c|c|c|c|c|c|}
\hline \multirow{2}{*}{ Country } & \multicolumn{3}{|c|}{ Water Collectors** } & \multicolumn{2}{|c|}{ Air Collectors** } & \multirow{2}{*}{ TOTAL $\left[\mathrm{MW}_{\mathrm{th}}\right]$} \\
\hline & unglazed & FPC & ETC & unglazed & glazed & \\
\hline Albania & & 5.2 & 0.1 & & & 5.3 \\
\hline Australia & 476.0 & 253.6 & 25.1 & & & 754.7 \\
\hline Austria & 3.9 & 187.7 & 8.3 & 0.2 & & 200.1 \\
\hline Belgium & & 21.9 & 4.9 & & & 26.8 \\
\hline Brazil & 345.6 & 331.1 & & & & 676.7 \\
\hline Bulgaria & & 5.4 & 0.5 & & & 5.9 \\
\hline Canada & 59.3 & 8.0 & 8.0 & 62.7 & 1.6 & 139.6 \\
\hline Chile & & 5.6 & & & & 5.6 \\
\hline China & & $2,100.0$ & $32,200.0$ & & & $34,300.0$ \\
\hline Cyprus & 0.1 & 23.1 & 1.2 & & & 24.4 \\
\hline Czech Republic & 37.1 & 51.7 & 12.4 & & & 101.2 \\
\hline Denmark & & 43.4 & 0.3 & & & 43.6 \\
\hline Estonia & & 0.1 & 0.3 & & & 0.4 \\
\hline Finland & & 2.8 & 1.4 & & & 4.2 \\
\hline France incl. DOM & & 221.9 & 6.3 & & & 228.2 \\
\hline Germany & & 724.5 & 80.5 & & & 805.0 \\
\hline Greece & & 148.8 & 1.1 & & & 149.8 \\
\hline Hungary & 1.7 & 10.3 & 4.4 & 0.2 & 0.1 & 16.7 \\
\hline India & & 425.9 & 196.3 & & & 622.2 \\
\hline Ireland & & 12.2 & 9.2 & & & 21.4 \\
\hline Israel & & 221.2 & & & & 221.2 \\
\hline Italy & & 299.3 & 43.8 & & & 343.0 \\
\hline Japan & & 102.8 & 3.4 & & 8.3 & 114.5 \\
\hline Jordan & 4.2 & 55.7 & 8.9 & & & 68.8 \\
\hline Korea, South & & 48.9 & & & & 48.9 \\
\hline Latvia & & 0.1 & 0.1 & & & 0.1 \\
\hline Lithuania & & 0.0 & 0.1 & & & 0.1 \\
\hline Luxembourg & & 2.5 & 0.7 & & & 3.2 \\
\hline Malta & & 1.2 & 0.8 & & & 2.0 \\
\hline Mexico & 63.0 & 66.5 & 59.5 & & 1.8 & 190.8 \\
\hline Morocco* & & 48.5 & & & & 48.5 \\
\hline Namibia & & 3.8 & 0.6 & & & 4.4 \\
\hline Netherlands & 18.6 & 32.1 & 2.8 & & & 53.5 \\
\hline Norway & 0.1 & 1.5 & 0.6 & & & 2.2 \\
\hline Poland & & 77.7 & 24.5 & & & 102.2 \\
\hline Portugal & 0.2 & 130.9 & 0.2 & & & 131.4 \\
\hline Romania & & 6.0 & 4.9 & & & 10.9 \\
\hline Slovakia & & 9.0 & 1.5 & & & 10.5 \\
\hline Slovenia & & 10.5 & 2.8 & & & 13.3 \\
\hline South Africa & 35.0 & 29.6 & 5.4 & & & 70.0 \\
\hline Spain & 7.7 & 220.9 & 15.1 & & & 243.6 \\
\hline Sweden & 12.0 & 9.5 & 5.0 & & & 26.5 \\
\hline Switzerland & 8.4 & 90.3 & 11.0 & 5.6 & & 115.3 \\
\hline Taiwan & 0.0 & 81.2 & 8.3 & & & 89.4 \\
\hline Tunisia & & 50.5 & 8.8 & & & 59.3 \\
\hline Turkey & & $1,160.6$ & & & & $1,160.6$ \\
\hline United Kingdom & & 52.9 & 20.7 & & & 73.6 \\
\hline United States & 656.5 & 157.8 & & & & 814.3 \\
\hline Zimbabwe & & 0.3 & 0.1 & & & 0.4 \\
\hline TOTAL & $1,729.3$ & $7,554.7$ & $32,789.4$ & 68.7 & 11.8 & $42,154.0$ \\
\hline
\end{tabular}

* Newly included countries compared to the 2011 edition of this report

** If no data is given: no reliable database for this collector type is available

Table 3: Newly installed capacity in $2010\left[\mathrm{MW}_{\mathrm{th}} / \mathrm{a}\right]$ 


\begin{tabular}{|c|c|c|c|c|c|c|}
\hline \multirow{2}{*}{ Country } & \multicolumn{3}{|c|}{ Water Collectors** } & \multicolumn{2}{|c|}{ Air Collectors** } & \multirow{2}{*}{ TOTAL $\left[\mathrm{m}^{2}\right]$} \\
\hline & unglazed & FPC & ETC & unglazed & glazed & \\
\hline Albania & & 7,480 & 82 & & & 7,562 \\
\hline Australia & 680,000 & 362,351 & 35,837 & & & $1,078,188$ \\
\hline Austria & 5,539 & 268,093 & 11,805 & 350 & & 285,787 \\
\hline Belgium & & 31,306 & 6,995 & & & 38,301 \\
\hline Brazil & 493,725 & 472,956 & & & & 966,681 \\
\hline Bulgaria & & 7,750 & 650 & & & 8,400 \\
\hline Canada & 84,690 & 11,481 & 11,493 & 89,560 & 2,267 & 199,491 \\
\hline Chile & & 7,937 & & & & 7,937 \\
\hline China & & $3,000,000$ & $46,000,000$ & & & $49,000,000$ \\
\hline Cyprus & 109 & 32,931 & 1,782 & & & 34,822 \\
\hline Czech Republic & 53,000 & 73,898 & 17,719 & & & 144,617 \\
\hline Denmark & & 61,944 & 400 & & & 62,344 \\
\hline Estonia & & 100 & 400 & & & 500 \\
\hline Finland & & 4,000 & 2,000 & & & 6,000 \\
\hline France incl. DOM & & 317,000 & 9,000 & & & 326,000 \\
\hline Germany & & $1,035,000$ & 115,000 & & & $1,150,000$ \\
\hline Greece & & 212,500 & 1,500 & & & 214,000 \\
\hline Hungary & 2,400 & 14,700 & 6,300 & 300 & 150 & 23,850 \\
\hline India & & 608,436 & 280,369 & & & 888,805 \\
\hline Ireland & & 17,472 & 13,109 & & & 30,581 \\
\hline Israel & & 316,000 & & & & 316,000 \\
\hline Italy & & 427,500 & 62,500 & & & 490,000 \\
\hline Japan & & 146,866 & 4,794 & & 11,850 & 163,511 \\
\hline Jordan & 5,940 & 79,621 & 12,654 & & & 98,215 \\
\hline Korea, South & & 69,805 & & & & 69,805 \\
\hline Latvia & & 100 & 100 & & & 200 \\
\hline Lithuania & & 50 & 150 & & & 200 \\
\hline Luxembourg & & 3,500 & 1,000 & & & 4,500 \\
\hline Malta & & 1,759 & 1,101 & & & 2,860 \\
\hline Mexico & 90,000 & 95,000 & 85,000 & & 2,580 & 272,580 \\
\hline Morocco* & & 69,260 & & & & 69,260 \\
\hline Namibia & & 5,440 & 860 & & & 6,300 \\
\hline Netherlands & 26,507 & 45,862 & 4,000 & & & 76,369 \\
\hline Norway & 170 & 2,123 & 813 & & & 3,106 \\
\hline Poland & & 111,000 & 35,000 & & & 146,000 \\
\hline Portugal & 353 & 186,990 & 302 & & & 187,645 \\
\hline Romania & & 8,500 & 7,000 & & & 15,500 \\
\hline Slovakia & & 12,800 & 2,200 & & & 15,000 \\
\hline Slovenia & & 15,000 & 4,000 & & & 19,000 \\
\hline South Africa & 50,000 & 42,300 & 7,700 & & & 100,000 \\
\hline Spain & 11,000 & 315,500 & 21,500 & & & 348,000 \\
\hline Sweden & 17,191 & 13,567 & 7,132 & & & 37,890 \\
\hline Switzerland & 11,944 & 129,026 & 15,746 & 8,000 & & 164,716 \\
\hline Taiwan & 2 & 115,938 & 11,811 & & & 127,751 \\
\hline Tunisia & & 72,200 & 12,500 & & & 84,700 \\
\hline Turkey & & $1,658,000$ & & & & $1,658,000$ \\
\hline United Kingdom & & 75,600 & 29,600 & & & 105,200 \\
\hline United States & 937,856 & 225,383 & & & & $1,163,239$ \\
\hline Zimbabwe & & 450 & 75 & & & 525 \\
\hline TOTAL & $2,470,426$ & $10,792,474$ & $46,841,980$ & 98,210 & 16,847 & $60,219,937$ \\
\hline
\end{tabular}

* Newly included countries

** If no data is given: no reliable database for this collector type is available

Table 4: Newly Installed collector area in 2010 [m²/a] 
As can be seen in Figure 16 evacuated tube collectors represent $77.8 \%$ and was by far the largest market share in a worldwide context, followed by flat plate collectors totaling in $17.9 \%$, unglazed water collectors with $4.1 \%$ and $0.2 \%$ of glazed and unglazed air collectors. In total, glazed water collectors (ETC + FPC) account for $95.7 \%$ of the total market.

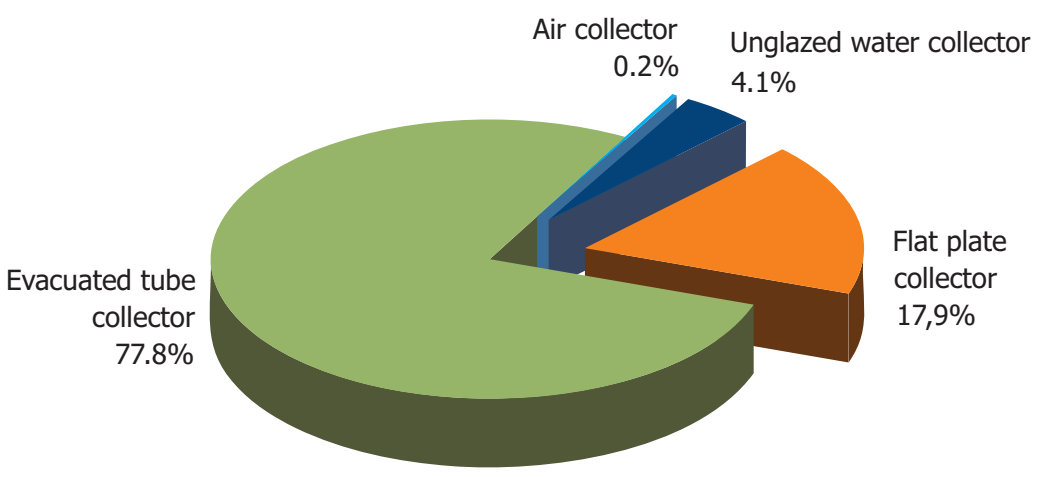

Figure 16: Distribution of the newly installed capacity by collector type in 2010

Figure 17 depicts the newly installed capacity of glazed and unglazed water collectors for the 10 leading markets in 2010 in total numbers.

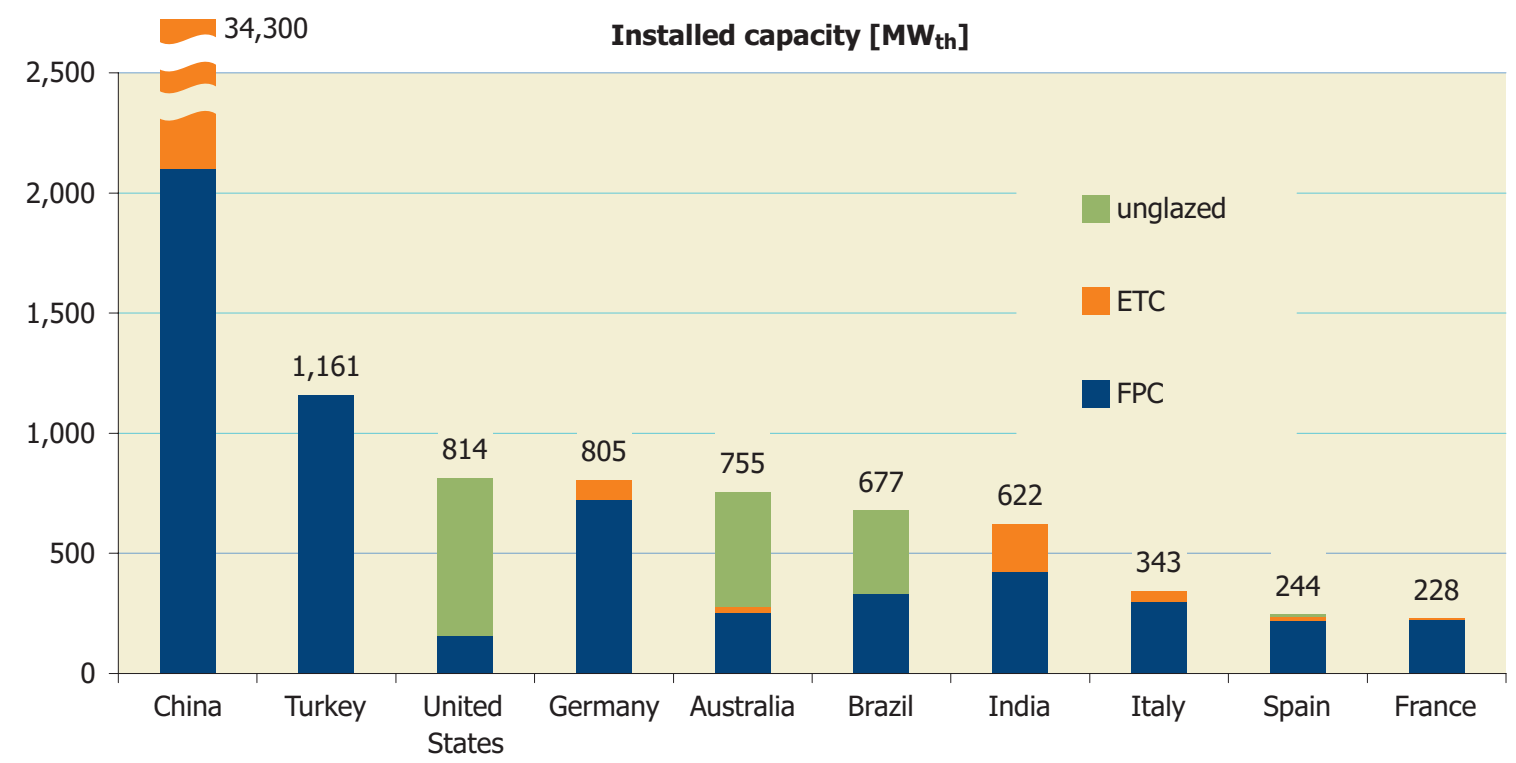

Figure 17: Total capacity of newly installed glazed and unglazed water collectors in the 10 leading countries in 2010

Compared to the newly installed capacity in 2009, China remained the market leader, however, Germany lost its second place position to Turkey and the United States, and Austria was displaced by France (including overseas departments) from the Top 10 ranking in 2010. 


\subsection{Newly installed capacity of glazed water collectors}

For glazed water collectors (FPC and ETC) the solar thermal market in 2010 grew by $13.8 \%$ with China once again as the strong driver for this successful development. Other than in 2009 when Germany held this position, Turkey has had the second largest market (see Figure 18).

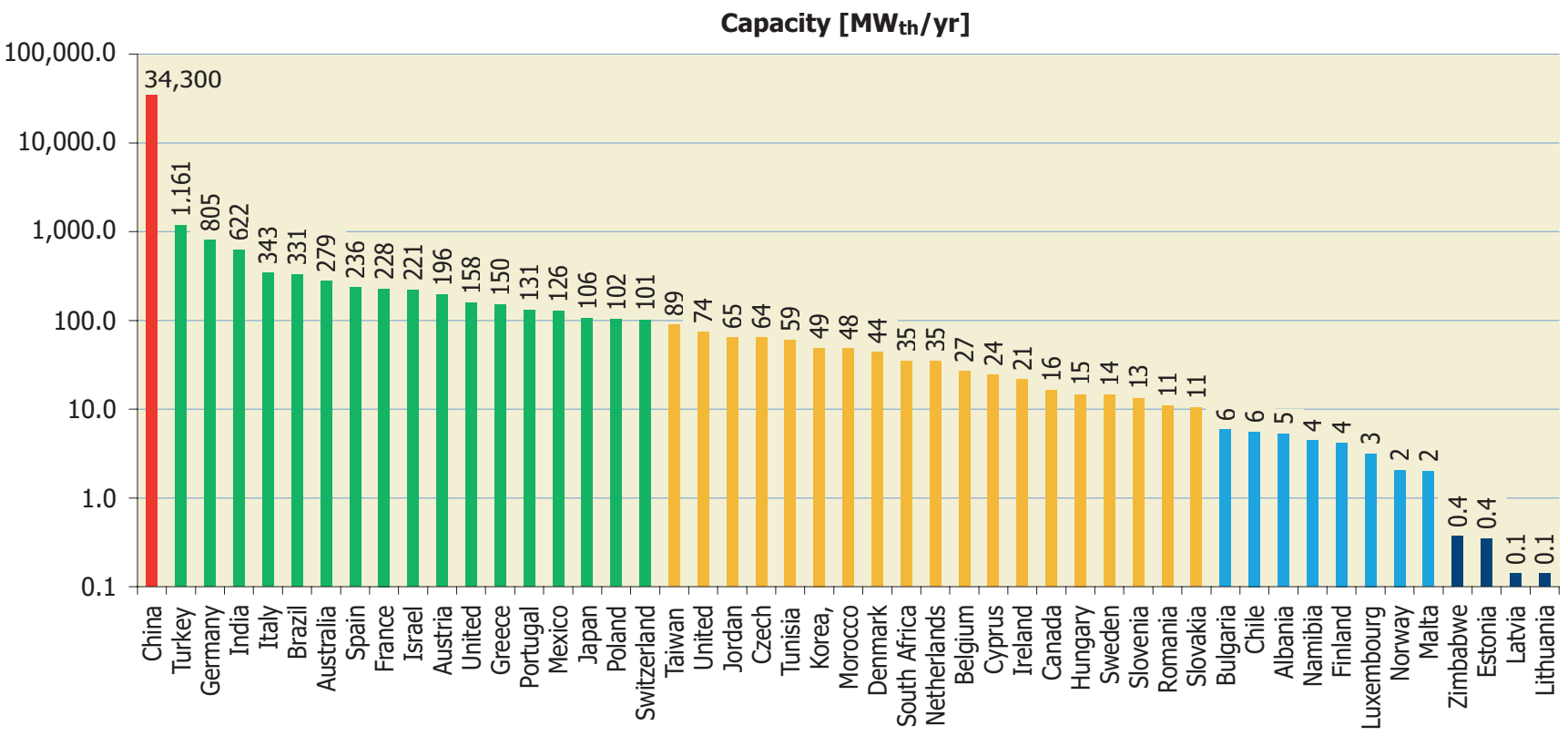

Figure 18: Newly installed capacity of glazed water collectors in 2010

In terms of newly installed capacity per 1,000 inhabitants, it is remarkable that China was close to leading the market only behind Israel, and ahead of Austria, Cyprus and Turkey. In other words this means that in $201043 \mathrm{~m}^{2}$ of new solar thermal collector area was installed in Israel per 1,000 inhabitants where the population accounted for about 7.4 million people and $37 \mathrm{~m}^{2}$ was installed in China where the population accounted for more than 1,330 million people (see Figure 19).

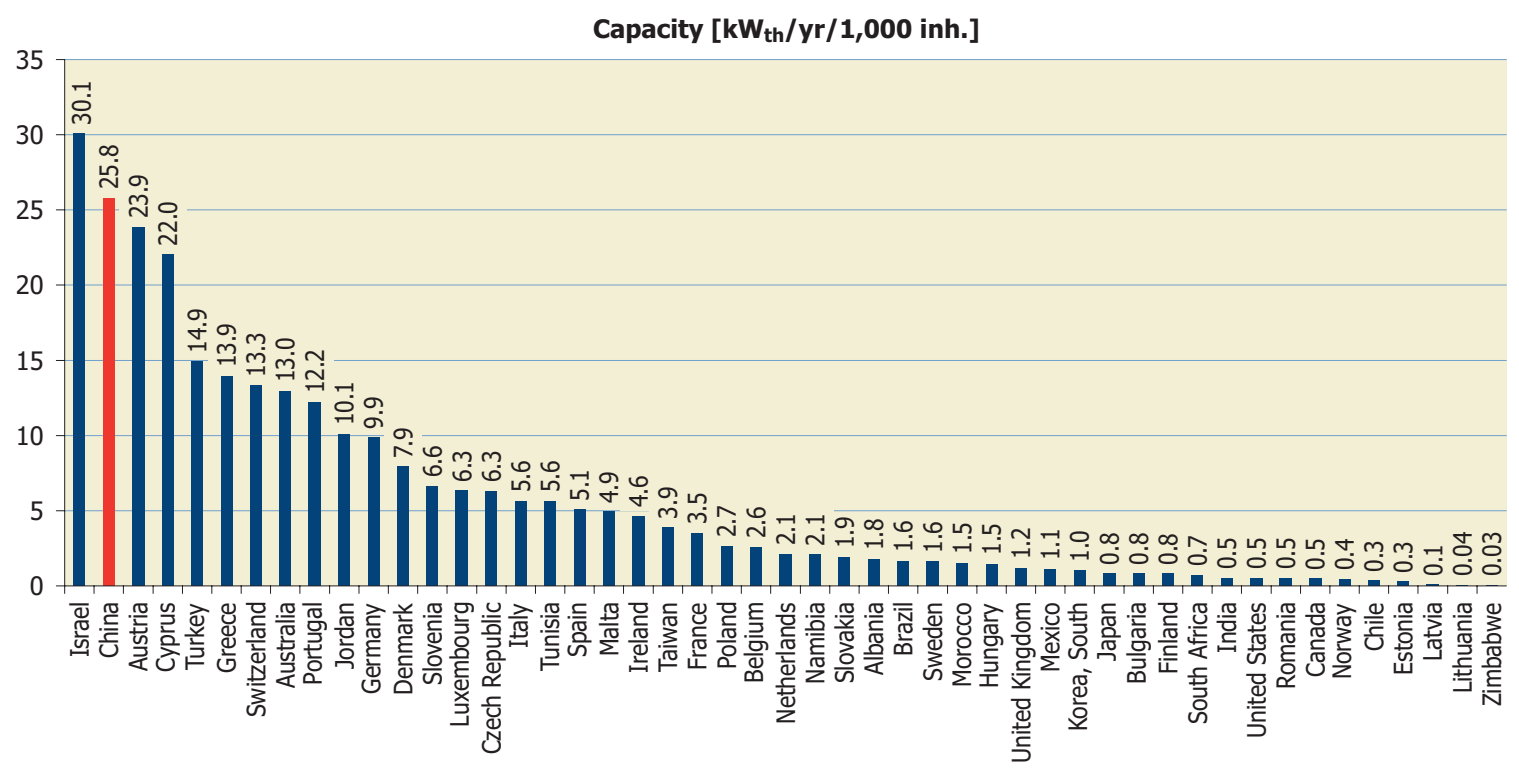

Figure 19: Newly installed capacity of glazed water collectors in 2010 in $\mathrm{kW}_{\text {th }}$ per 1,000 inhabitants 


\subsection{Market development of glazed water collectors between 2000 and 2010}

The worldwide market development of glazed water collectors is characterized by a steady growth over the past decade. Between 2000 and 2010 the average growth rate worldwide was about 21\%.

Between 2000 and 2010 the annual installed glazed water collector area worldwide increased 6-fold, and compared to the year 2009 the worldwide market grew by $13.8 \%$. Regardless of this positive development, it should be noted that the growth 2009/2010 rate was the lowest since the period 2004/2005 (see Figure 20).

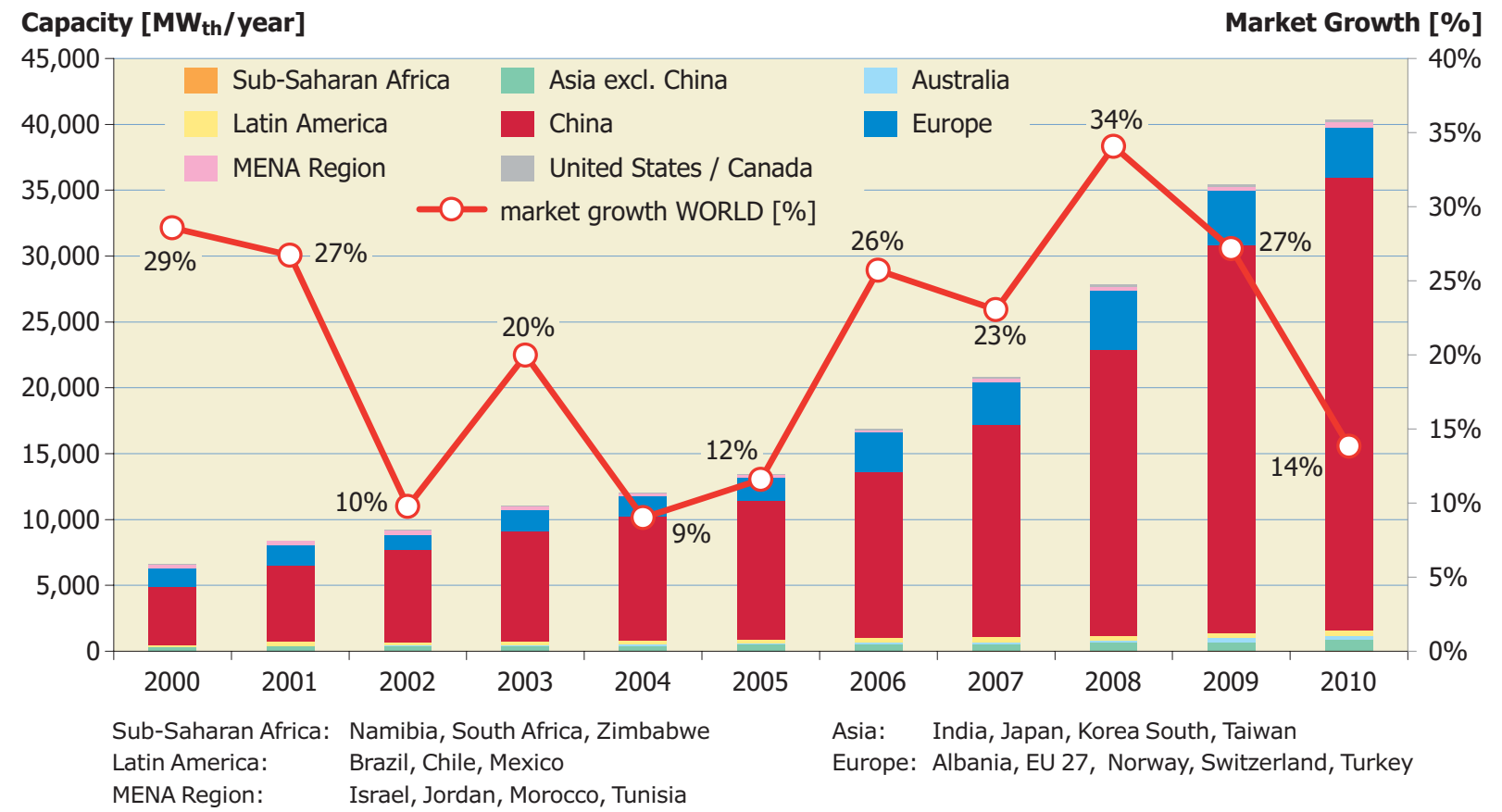

Figure 20: Annual installed capacity of flat plate and evacuated tube collectors from 2000 to 2010

The strong influence of the Chinese market on the worldwide market development is illustrated below in Figure 21.

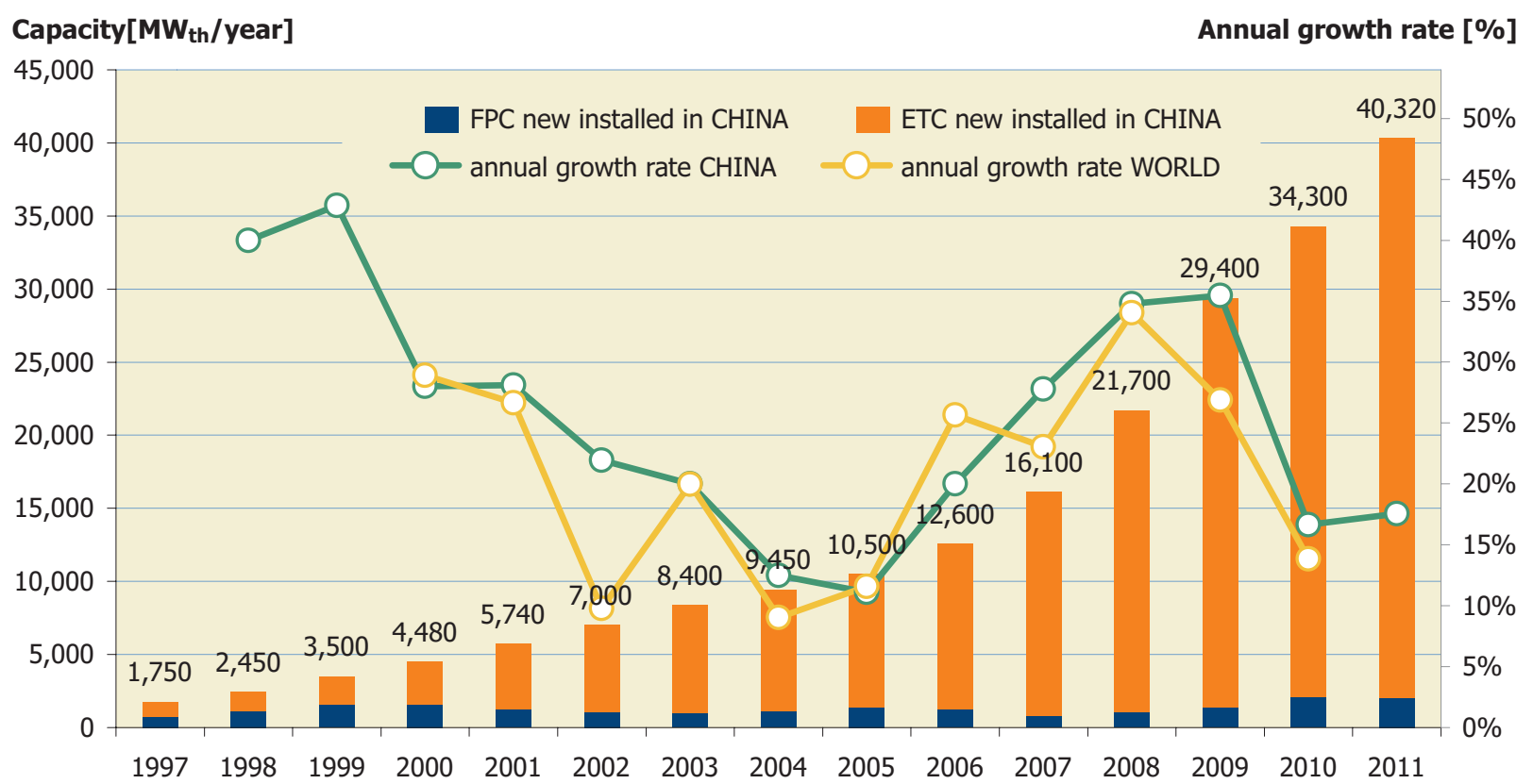

Figure 21: Annual installed capacity of flat-plate and evacuated tube collectors in China from 1997 to 2011 in comparison to the annual growth rates in China and the World 
Figure 22 shows the market development between 2000 and 2010 for the annually installed capacity of glazed water collectors per 1,000 inhabitants.

In the year 2000, the installed capacity per capita was similar in Australia, China and Europe and some MENA countries, most notably Israel and Jordan which peaked at a high level at this time. Since 2000 the Chinese and Australian markets have grown steadily while the European market has experienced average growth with some fluctuations. By 2009/2010, the European market decreased along with the Australian market in 2010 while in China the upwards trend has remained unbroken.

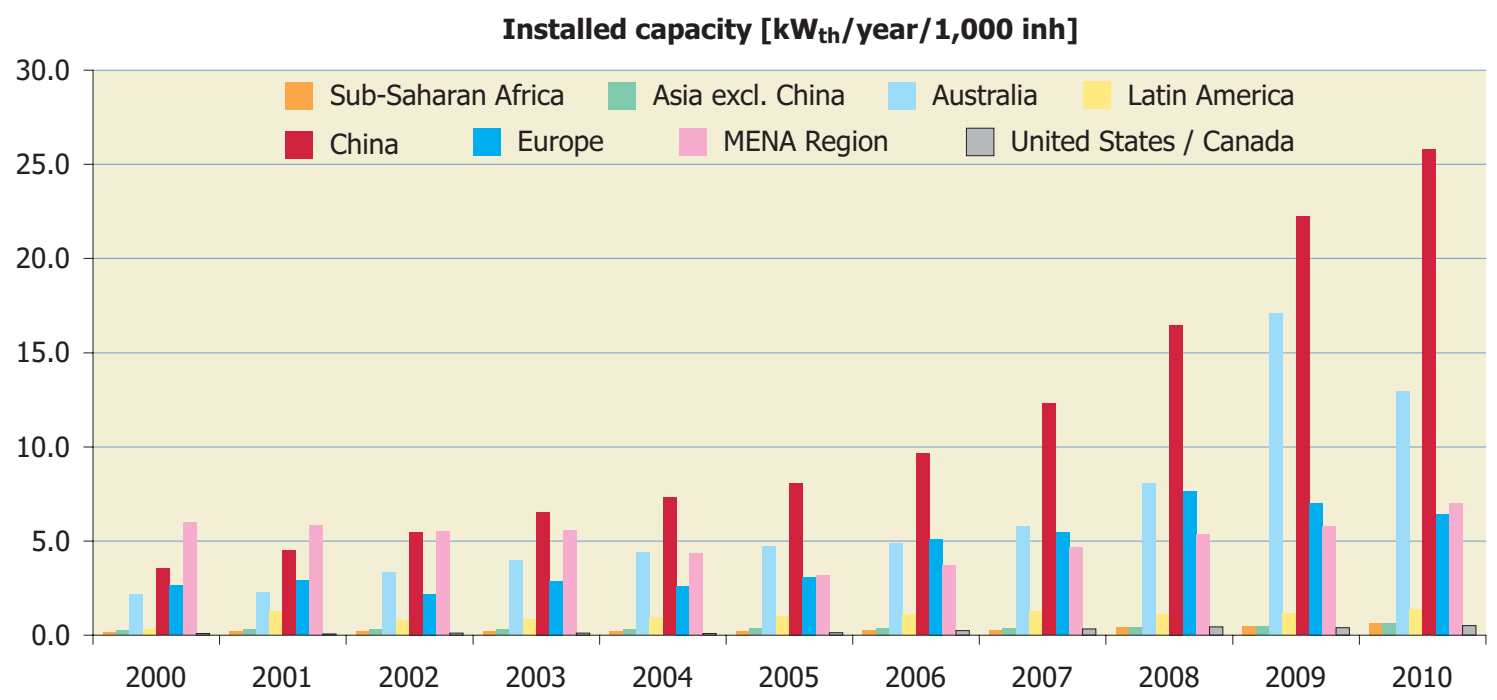

Figure 22: Annual installed capacity of flat plate and evacuated tube collectors in $\mathrm{kW}_{\text {th }}$ per 1,000 inhabitants from 2000 to 2010 


\subsection{Market development of unglazed water collectors between 2000 and 2010}

The worldwide market of unglazed collectors recorded a significant increase in 2001 and remained steady between 2001 and 2003. After a slight increase from 2004 to 2006, the installed capacity rate stagnated in 2007, mainly due to a market decline in the United States and Canada.

From 2007 to 2010 the market fluctuated primarily due to changing markets in the United States and in South America, most notably in Brazil. The large US market remained stable between 2007 and 2008 before a significant decrease in 2009 and then a market recovery in 2010. In contrast, the Australian market for unglazed water collectors remained quite stable at a high level between 2007 and 2010 and the Brazilian market experienced very high growth rates during the same period.

In total, new installations of unglazed water collectors increased by $13.6 \%$ in 2010 compared to 2009 , accounting for $1.73 \mathrm{GW}_{\text {th }}$ respectively 2.47 millions of square meters.

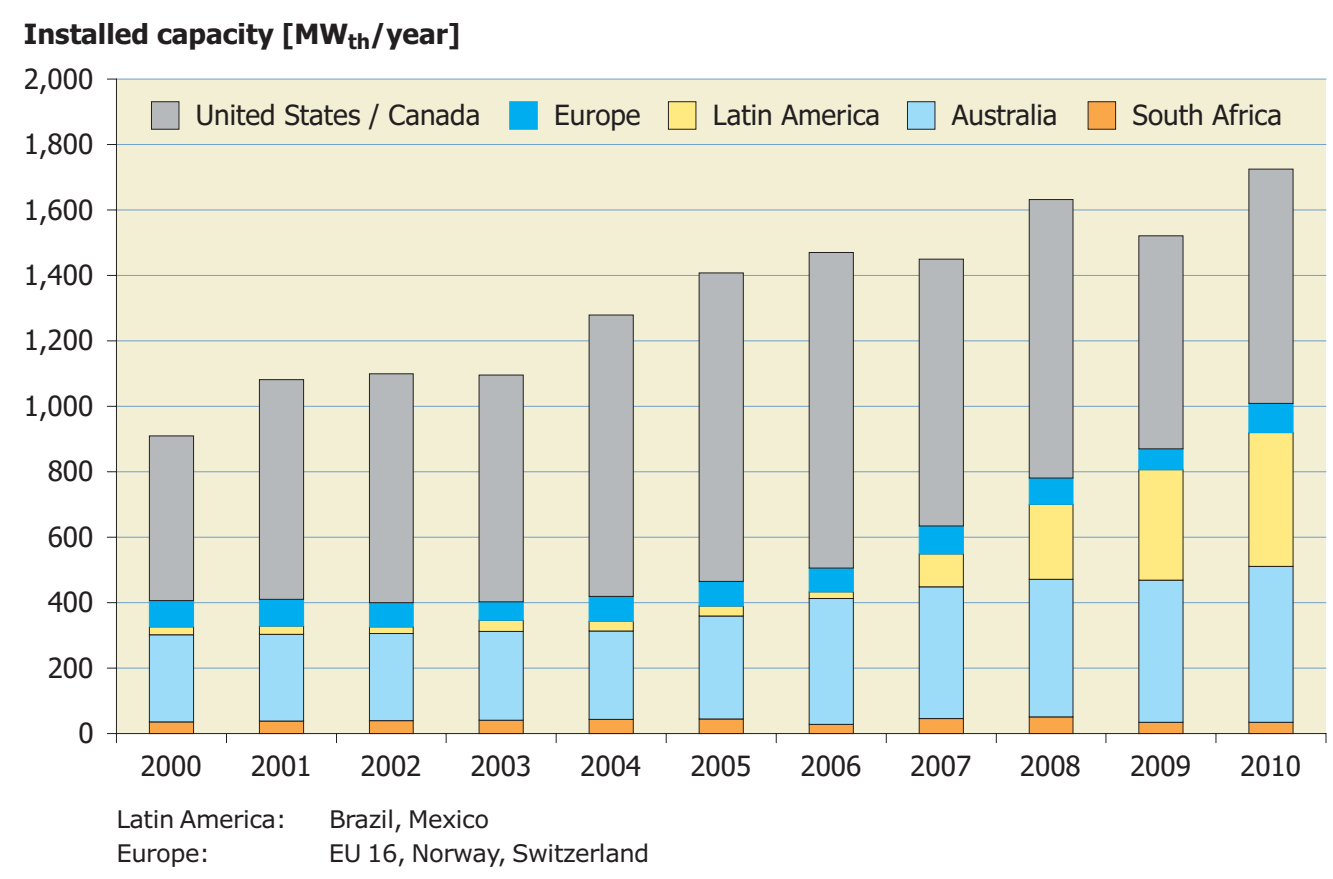

Figure 23: Annual installed capacity of unglazed water collectors from 2000 to 2010 


\section{Contribution to the energy supply and $\mathrm{CO}_{2}$ reduction}

In this section, the contribution of the total installed glazed and unglazed water collectors in operation to the thermal energy supply and $\mathrm{CO}_{2}$ reduction is shown.

The basis for these calculations is the total glazed and unglazed water collector area in operation in each country as shown in Table 1. The corresponding annual energy gains, energy savings expressed as oil equivalents and $\mathrm{CO}_{2}$ emission savings from the systems installed considering different types of solar collectors, geographic regions and types of applications are calculated with the simulation tool T-SOL expert 4.5 (www.valentin.de).

The annual collector yield of all water-based solar thermal systems in operation by the end of 2010 in the 55 recorded countries is $162,125 \mathrm{GWh}$ ( $=583,649 \mathrm{TJ}$ ). This corresponds to energy savings equivalent to 17.3 million tons of oil and 53.1 million tons of $\mathrm{CO}_{2}$. The calculated number of different types of solar thermal systems in operation exceeds 53 million by the end of 2010 .

For glazed water collectors, the cumulated capacity in operation by the end of 2010 of $173.0 \mathrm{GW}_{\text {th }}$ led to an annual solar thermal collector yield of $149,985 \mathrm{GWh}(=539,947 \mathrm{TJ} / \mathrm{a})$. This corresponds to annual oil savings of 16.1 million tons respectively to annual $\mathrm{CO}_{2}$ savings of 49.5 million tons.

For unglazed water collectors, the total installed capacity in operation in 2010 of $21.5 \mathrm{GW}_{\text {th }}$ led to an annual solar thermal collector yield of $12,139 \mathrm{GWh}(=43,702 \mathrm{TJ} / \mathrm{a})$. This corresponds to energy savings equivalent to 1.2 million tons of oil and 3.6 million tons of $\mathrm{CO}_{2}$.

The contribution of the total installed air collector capacity in operation in 2010 (1.3 GW $\left.\mathrm{Gh}_{\text {th }}\right)$ was not taken into consideration - with a share of around $0.6 \%$ of the total installed collector capacity, air collectors were omitted from the calculation.

Within the standardization of definitions for renewable heat by EUROSTAT and IEA SHC, a new calculation method for the annual solar yield was used in this report as well as in the 2011 edition of this report:

"Solar thermal production (solar yield) is equal to the solar collector output".

This new definition led to higher annual solar yields than reported in all reports prior to the 2011 edition.

Please find the description of the methodology in the appendix (see Chapter 7.1).

Table 5 summarizes the calculated annual collector yields and the corresponding oil equivalents and $\mathrm{CO}_{2}$ reductions of all solar thermal systems (systems for hot water, space heating and swimming pool heating) installed by the end of 2010.

Table 6 and Table 7 show the results for glazed and unglazed water collectors accordingly.

In Chapters 5.1 to 5.3, the annual collector yield, energy savings and $\mathrm{CO}_{2}$ savings by economic regions for total numbers and per 1,000 inhabitants are graphed. 


\begin{tabular}{|c|c|c|c|c|c|c|c|}
\hline Country & $\begin{array}{c}\text { Total } \\
\text { collector } \\
\text { area }\left[\mathbf{m}^{2}\right]\end{array}$ & $\begin{array}{c}\text { Total } \\
\text { capacity } \\
{\left[\mathrm{MW}_{\text {th }}\right]}\end{array}$ & $\begin{array}{c}\text { Calculated } \\
\text { number of } \\
\text { systems }\end{array}$ & $\begin{array}{l}\text { Collector } \\
\text { yield } \\
\text { [GWh/a] }\end{array}$ & $\begin{array}{l}\text { Collector } \\
\text { yield } \\
\text { [TJ/a] }\end{array}$ & $\begin{array}{l}\text { Energy } \\
\text { savings } \\
\text { [toe/a] }\end{array}$ & $\begin{array}{c}\mathrm{CO}_{2} \\
\text { reduction } \\
{\left[\mathrm{tCO}_{2} / \mathrm{a}\right]}\end{array}$ \\
\hline Albania & 77.733 & 54 & 10.121 & 57 & 205 & 6.107 & 18.747 \\
\hline Australia & 8.315 .563 & 5.821 & 636.198 & 4.971 & 17.897 & 504.255 & 1.548 .050 \\
\hline Austria & 4.558 .278 & 3.191 & 429.307 & 1.832 & 6.594 & 194.841 & 598.156 \\
\hline Barbados & 131.690 & 92 & 32.923 & 116 & 418 & 12.491 & 38.346 \\
\hline Belgium & 363.509 & 254 & 79.393 & 146 & 527 & 15.584 & 47.841 \\
\hline Brazil & 6.111 .477 & 4.278 & 1.059 .307 & 4.285 & 15.427 & 454.887 & 1.396 .489 \\
\hline Bulgaria & 46.736 & 33 & 8.595 & 24 & 88 & 2.619 & 8.039 \\
\hline Canada & 722.699 & 506 & 9.462 & 293 & 1.053 & 28.419 & 87.247 \\
\hline Chile & 28.159 & 20 & 3.542 & 21 & 77 & 2.285 & 7.014 \\
\hline China & 168.000 .000 & 117.600 & 38.295 .600 & 97.682 & 351.654 & 10.498 .876 & 32.231 .249 \\
\hline Cyprus & 908.784 & 636 & 200.009 & 808 & 2.908 & 86.807 & 266.495 \\
\hline Czech Republic & 457.939 & 321 & 40.710 & 162 & 582 & 16.833 & 51.676 \\
\hline Denmark & 550.409 & 385 & 115.849 & 246 & 885 & 26.354 & 80.906 \\
\hline Estonia & 2.841 & 2 & 710 & 1 & 4 & 132 & 405 \\
\hline Finland & 46.240 & 32 & 8.278 & 19 & 68 & 1.980 & 6.078 \\
\hline France incl.DOM & 2.282 .877 & 1.598 & 438.088 & 1.074 & 3.865 & 115.043 & 353.180 \\
\hline Germany & 13.720 .164 & 9.604 & 1.482 .977 & 5.565 & 20.035 & 595.784 & 1.829 .041 \\
\hline Greece & 4.087 .000 & 2.861 & 1.603 .739 & 3.146 & 11.327 & 338.180 & 1.038 .203 \\
\hline Hungary & 157.902 & 111 & 15.731 & 75 & 270 & 8.027 & 24.644 \\
\hline India & 3.970 .000 & 2.779 & 809.880 & 3.397 & 12.229 & 365.114 & 1.120 .889 \\
\hline Ireland & 151.598 & 106 & 34.990 & 63 & 228 & 6.815 & 20.923 \\
\hline Israel & 4.167.795 & 2.917 & 273.251 & 3.591 & 12.929 & 385.788 & 1.184 .358 \\
\hline Italy & 2.591 .344 & 1.814 & 637.113 & 1.704 & 6.134 & 182.890 & 561.466 \\
\hline Japan & 5.300 .983 & 3.711 & 1.303 .933 & 3.090 & 11.122 & 332.065 & 1.019 .431 \\
\hline Jordan & 993.502 & 695 & 201.492 & 941 & 3.387 & 101.084 & 310.324 \\
\hline Korea, South & 1.566 .319 & 1.096 & 225.863 & 819 & 2.948 & 88.020 & 270.219 \\
\hline Latvia & 7.244 & 5 & 1.811 & 3 & 12 & 359 & 1.103 \\
\hline Lebanon & 348.312 & 244 & 87.078 & 333 & 1.197 & 35.751 & 109.753 \\
\hline Lithuania & 4.518 & 3 & 1.130 & 2 & 7 & 219 & 671 \\
\hline Luxembourg & 30.800 & 22 & 7.700 & 14 & 50 & 1.488 & 4.569 \\
\hline Macedonia & 25.744 & 18 & 3.298 & 15 & 56 & 1.665 & 5.111 \\
\hline Malta & 43.469 & 30 & 10.867 & 38 & 136 & 4.055 & 12.448 \\
\hline Mexico & 1.531 .954 & 1.072 & 76.727 & 809 & 2.912 & 84.476 & 259.338 \\
\hline Morocco & 341.260 & 239 & 85.315 & 349 & 1.256 & 37.486 & 115.080 \\
\hline Namibia & 22.006 & 15 & 2.718 & 20 & 72 & 2.158 & 6.624 \\
\hline Netherlands & 811.231 & 568 & 117.302 & 287 & 1.034 & 29.596 & 90.860 \\
\hline New Zealand & 159.645 & 112 & 36.435 & 101 & 365 & 10.861 & 33.343 \\
\hline Norway & 17.471 & 12 & 2.551 & 7 & 26 & 775 & 2.379 \\
\hline Poland & 655.800 & 459 & 82.522 & 268 & 964 & 28.783 & 88.364 \\
\hline Portugal & 753.793 & 528 & 136.008 & 583 & 2.099 & 62.643 & 192.312 \\
\hline Romania & 109.996 & 77 & 27.499 & 65 & 235 & 7.018 & 21.546 \\
\hline Slovakia & 135.746 & 95 & 22.624 & 65 & 235 & 7.013 & 21.530 \\
\hline Slovenia & 163.698 & 115 & 24.757 & 68 & 245 & 7.320 & 22.472 \\
\hline South Africa & 1.163 .360 & 814 & 93.939 & 769 & 2.768 & 77.798 & 238.838 \\
\hline Spain & 2.460 .000 & 1.722 & 248.906 & 1.700 & 6.120 & 182.019 & 558.794 \\
\hline Sweden & 442.000 & 309 & 25.514 & 160 & 577 & 16.739 & 51.387 \\
\hline Switzerland & 1.008 .110 & 706 & 107.709 & 393 & 1.414 & 41.500 & 127.404 \\
\hline Taiwan & 2.045 .847 & 1.432 & 485.562 & 1.249 & 4.497 & 134.272 & 412.211 \\
\hline Thailand & 91.392 & 64 & 22.848 & 78 & 281 & 8.385 & 25.741 \\
\hline Tunisia & 489.700 & 343 & 119.046 & 439 & 1.582 & 47.230 & 144.996 \\
\hline Turkey & 13.318 .659 & 9.323 & 3.084 .601 & 10.846 & 39.044 & 1.165 .688 & 3.578 .630 \\
\hline United Kingdom & 564.783 & 395 & 141.196 & 235 & 844 & 25.207 & 77.385 \\
\hline United States & 21.807 .440 & 15.265 & 504.529 & 9.076 & 32.674 & 885.972 & 2.719 .908 \\
\hline Uruguay & 12.096 & 8 & 3.024 & 8 & 30 & 886 & 2.720 \\
\hline Zimbabwe & 18.196 & 13 & 4.549 & 16 & 56 & 1.671 & 5.128 \\
\hline TOTAL & 277.895 .811 & 194.527 & 53.524 .825 & 162.125 & 583.649 & 17.280 .312 & 53.050 .066 \\
\hline
\end{tabular}

Table 5: Calculated annual collector yield and corresponding oil equivalent as well as $\mathrm{CO}_{2}$ reduction of glazed and unglazed water collectors in operation by the end of 2010 


\begin{tabular}{|c|c|c|c|c|c|c|c|}
\hline Country & $\begin{array}{c}\text { Total } \\
\text { collector } \\
\text { area }\left[\mathbf{m}^{2}\right]\end{array}$ & $\begin{array}{c}\text { Total } \\
\text { capacity } \\
{\left[\mathrm{MW}_{\mathrm{th}}\right]}\end{array}$ & $\begin{array}{c}\text { Calculated } \\
\text { number of } \\
\text { systems }\end{array}$ & $\begin{array}{c}\text { Collector } \\
\text { yield } \\
\text { [GWh/a] }\end{array}$ & $\begin{array}{c}\text { Collector } \\
\text { yield } \\
\text { [TJ/a] }\end{array}$ & $\begin{array}{l}\text { Energy } \\
\text { savings } \\
\text { [toe/a] }\end{array}$ & $\begin{array}{c}\mathrm{CO}_{2} \text { reduc- } \\
\text { tion } \\
{\left[\mathrm{tCO}_{2} / \mathrm{a}\right]}\end{array}$ \\
\hline Albania & 77.733 & 54 & 10.121 & 57 & 205 & 6.107 & 18.747 \\
\hline Australia & 2.915 .563 & 2.041 & 477.375 & 2.454 & 8.835 & 263.786 & 809.815 \\
\hline Austria & 3.958 .787 & 2.771 & 426.309 & 1.662 & 5.982 & 178.605 & 548.313 \\
\hline Barbados & 131.690 & 92 & 32.923 & 116 & 418 & 12.491 & 38.346 \\
\hline Belgium & 316.634 & 222 & 79.159 & 134 & 483 & 14.407 & 44.229 \\
\hline Brazil & 4.834 .349 & 3.384 & 1.052 .921 & 3.807 & 13.706 & 409.188 & 1.256 .197 \\
\hline Bulgaria & 46.736 & 33 & 8.595 & 24 & 88 & 2.619 & 8.039 \\
\hline Canada & 66.214 & 46 & 6.180 & 39 & 140 & 4.191 & 12.868 \\
\hline Chile & 28.159 & 20 & 3.542 & 21 & 77 & 2.285 & 7.014 \\
\hline China & 168.000 .000 & 117.600 & 38.295 .600 & 97.682 & 351.654 & 10.498 .876 & 32.231 .249 \\
\hline Cyprus & 905.421 & 634 & 199.992 & 806 & 2.901 & 86.620 & 265.922 \\
\hline Czech Republic & 307.939 & 216 & 39.960 & 116 & 419 & 12.496 & 38.361 \\
\hline Denmark & 529.894 & 371 & 115.746 & 240 & 863 & 25.776 & 79.133 \\
\hline Estonia & 2.841 & 2 & 710 & 1 & 4 & 132 & 405 \\
\hline Finland & 34.461 & 24 & 8.219 & 15 & 55 & 1.633 & 5.014 \\
\hline Franceincl.DOM & 2.193 .696 & 1.536 & 437.642 & 1.044 & 3.760 & 112.248 & 344.599 \\
\hline Germany & 13.083 .154 & 9.158 & 1.479 .792 & 5.366 & 19.316 & 576.700 & 1.770 .454 \\
\hline Greece & 4.087 .000 & 2.861 & 1.603 .739 & 3.146 & 11.327 & 338.180 & 1.038 .203 \\
\hline Hungary & 149.814 & 105 & 15.691 & 72 & 260 & 7.761 & 23.827 \\
\hline India & 3.970 .000 & 2.779 & 809.880 & 3.397 & 12.229 & 365.114 & 1.120 .889 \\
\hline Ireland & 151.177 & 106 & 34.987 & 63 & 228 & 6.803 & 20.885 \\
\hline Israel & 4.137 .895 & 2.897 & 273.101 & 3.574 & 12.867 & 384.166 & 1.179 .380 \\
\hline Italy & 2.547 .578 & 1.783 & 636.895 & 1.684 & 6.064 & 181.042 & 555.794 \\
\hline Japan & 5.300 .983 & 3.711 & 1.303 .933 & 3.090 & 11.122 & 332.065 & 1.019 .431 \\
\hline Jordan & 987.562 & 691 & 201.463 & 937 & 3.373 & 100.716 & 309.194 \\
\hline Korea, South & 1.566 .319 & 1.096 & 225.863 & 819 & 2.948 & 88.020 & 270.219 \\
\hline Latvia & 7.244 & 5 & 1.811 & 3 & 12 & 359 & 1.103 \\
\hline Lebanon & 348.312 & 244 & 87.078 & 333 & 1.197 & 35.751 & 109.753 \\
\hline Lithuania & 4.518 & 3 & 1.130 & 2 & 7 & 219 & 671 \\
\hline Luxembourg & 30.800 & 22 & 7.700 & 14 & 50 & 1.488 & 4.569 \\
\hline Macedonia & 25.744 & 18 & 3.298 & 15 & 56 & 1.665 & 5.111 \\
\hline Malta & 43.469 & 30 & 10.867 & 38 & 136 & 4.055 & 12.448 \\
\hline Mexico & 869.862 & 609 & 73.416 & 603 & 2.170 & 64.779 & 198.871 \\
\hline Morocco & 341.260 & 239 & 85.315 & 349 & 1.256 & 37.486 & 115.080 \\
\hline Namibia & 22.006 & 15 & 2.718 & 20 & 72 & 2.158 & 6.624 \\
\hline Netherlands & 414.821 & 290 & 115.320 & 179 & 646 & 19.289 & 59.218 \\
\hline New Zealand & 152.620 & 107 & 36.400 & 98 & 354 & 10.583 & 32.490 \\
\hline Norway & 15.460 & 11 & 2.541 & 7 & 24 & 714 & 2.192 \\
\hline Poland & 655.800 & 459 & 82.522 & 268 & 964 & 28.783 & 88.364 \\
\hline Portugal & 751.358 & 526 & 135.996 & 582 & 2.095 & 62.545 & 192.012 \\
\hline Romania & 109.996 & 77 & 27.499 & 65 & 235 & 7.018 & 21.546 \\
\hline Slovakia & 135.746 & 95 & 22.624 & 65 & 235 & 7.013 & 21.530 \\
\hline Slovenia & 163.698 & 115 & 24.757 & 68 & 245 & 7.320 & 22.472 \\
\hline South Africa & 359.682 & 252 & 89.920 & 363 & 1.307 & 39.011 & 119.763 \\
\hline Spain & 2.338 .000 & 1.637 & 248.296 & 1.642 & 5.912 & 176.522 & 541.918 \\
\hline Sweden & 302.000 & 211 & 24.814 & 119 & 429 & 12.796 & 39.283 \\
\hline Switzerland & 795.260 & 557 & 106.644 & 334 & 1.202 & 35.876 & 110.139 \\
\hline Taiwan & 2.045 .761 & 1.432 & 485.561 & 1.249 & 4.497 & 134.269 & 412.203 \\
\hline ItThailand & 91.392 & 64 & 22.848 & 78 & 281 & 8.385 & 25.741 \\
\hline Tunisia & 489.700 & 343 & 119.046 & 439 & 1.582 & 47.230 & 144.996 \\
\hline Turkey & 13.318.659 & 9.323 & 3.084 .601 & 10.846 & 39.044 & 1.165 .688 & 3.578 .630 \\
\hline United Kingdom & 564.783 & 395 & 141.196 & 235 & 844 & 25.207 & 77.385 \\
\hline United States & 2.446 .342 & 1.712 & 407.724 & 1.579 & 5.685 & 169.730 & 521.065 \\
\hline Uruguay & 12.096 & 8 & 3.024 & 8 & 30 & 886 & 2.720 \\
\hline Zimbabwe & 18.196 & 13 & 4.549 & 16 & 56 & 1.671 & 5.128 \\
\hline TOTAL & 247.206 .184 & 173.044 & 53.239 .553 & 149.985 & 539.947 & 16.120 .526 & 49.489 .555 \\
\hline
\end{tabular}

Table 6: Calculated annual collector yield and corresponding oil equivalent as well as $\mathrm{CO}_{2}$ reduction of glazed $($ FPC + ETC) water collectors in operation by the end of 2010 


\begin{tabular}{|c|c|c|c|c|c|c|c|}
\hline Country & $\begin{array}{c}\text { Total } \\
\text { collector } \\
\text { area }\left[\mathrm{m}^{2}\right]\end{array}$ & $\begin{array}{c}\text { Total } \\
\text { capacity } \\
{\left[\mathrm{MW}_{\mathrm{th}}\right]}\end{array}$ & $\begin{array}{c}\text { Calculated } \\
\text { number of } \\
\text { systems }\end{array}$ & $\begin{array}{l}\text { Collector } \\
\text { yield } \\
\text { [GWh/a] }\end{array}$ & $\begin{array}{l}\text { Collector } \\
\text { yield } \\
\text { [TJ/a] }\end{array}$ & $\begin{array}{l}\text { Energy } \\
\text { savings } \\
\text { [toe/a] }\end{array}$ & $\begin{array}{c}\mathrm{CO}_{2} \\
\text { reduction } \\
{\left[\mathrm{tCO}_{2} / \mathrm{a}\right]}\end{array}$ \\
\hline \multicolumn{8}{|l|}{ Albania } \\
\hline Australia & 5.400 .000 & 3.780 & 158.824 & 2.517 & 9.061 & 240.469 & 738.234 \\
\hline Austria & 599.491 & 420 & 2.997 & 170 & 612 & 16.236 & 49.843 \\
\hline \multicolumn{8}{|l|}{ Barbados } \\
\hline Belgium & 46.875 & 33 & 234 & 12 & 44 & 1.176 & 3.611 \\
\hline Brazil & 1.277 .128 & 894 & 6.386 & 478 & 1.722 & 45.698 & 140.292 \\
\hline \multicolumn{8}{|l|}{ Bulgaria } \\
\hline Canada & 656.485 & 460 & 3.282 & 254 & 913 & 24.228 & 74.379 \\
\hline \multicolumn{8}{|l|}{ Chile } \\
\hline \multicolumn{8}{|l|}{ China } \\
\hline Cyprus & 3.363 & 2 & 17 & 2 & 7 & 187 & 573 \\
\hline Czech Republic & 150.000 & 105 & 750 & 45 & 163 & 4.337 & 13.315 \\
\hline Denmark & 20.515 & 14 & 103 & 6 & 22 & 578 & 1.774 \\
\hline \multicolumn{8}{|l|}{ Estonia } \\
\hline Finland & 11.779 & 8 & 59 & 4 & 13 & 347 & 1.064 \\
\hline France incl.DOM & 89.181 & 62 & 446 & 29 & 105 & 2.795 & 8.581 \\
\hline Germany & 637.010 & 446 & 3.185 & 200 & 719 & 19.084 & 58.588 \\
\hline \multicolumn{8}{|l|}{ Greece } \\
\hline Hungary & 8.088 & 6 & 40 & 3 & 10 & 266 & 816 \\
\hline \multicolumn{8}{|l|}{ India } \\
\hline Ireland & 421 & 0 & 2 & 0 & 0 & 12 & 37 \\
\hline Israel & 29.900 & 21 & 150 & 17 & 61 & 1.622 & 4.979 \\
\hline Italy & 43.766 & 31 & 219 & 19 & 70 & 1.848 & 5.672 \\
\hline \multicolumn{8}{|l|}{ Japan } \\
\hline Jordan & 5.940 & 4 & 30 & 4 & 14 & 368 & 1.130 \\
\hline \multicolumn{8}{|l|}{ Korea, South } \\
\hline \multicolumn{8}{|l|}{ Latvia } \\
\hline \multicolumn{8}{|l|}{ Lebanon } \\
\hline \multicolumn{8}{|l|}{ Lithuania } \\
\hline \multicolumn{8}{|l|}{ Luxembourg } \\
\hline \multicolumn{8}{|l|}{ Macedonia } \\
\hline \multicolumn{8}{|l|}{ Malta } \\
\hline Mexico & 662.092 & 463 & 3.310 & 206 & 742 & 19.696 & 60.467 \\
\hline \multicolumn{8}{|l|}{ Morocco } \\
\hline Namibia & & & & & & & \\
\hline Netherlands & 396.410 & 277 & 1.982 & 108 & 388 & 10.307 & 31.642 \\
\hline New Zealand & 7.025 & 5 & 35 & 3 & 10 & 278 & 853 \\
\hline Norway & 2.011 & 1 & 10 & 1 & 2 & 61 & 187 \\
\hline Poland & & & & & & & \\
\hline Portugal & 2.435 & 2 & 12 & 1 & 4 & 98 & 301 \\
\hline Romania & & & & & & & \\
\hline Slovakia & & & & & & & \\
\hline Slovenia & & & & & & & \\
\hline South Africa & 803.678 & 563 & 4.018 & 406 & 1.462 & 38.787 & 119.076 \\
\hline Spain & 122.000 & 85 & 610 & 58 & 207 & 5.497 & 16.877 \\
\hline Sweden & 140.000 & 98 & 700 & 41 & 149 & 3.943 & 12.104 \\
\hline Switzerland & 212.850 & 149 & 1.064 & 59 & 212 & 5.624 & 17.265 \\
\hline Taiwan & 85 & 0 & 0 & 0 & 0 & 3 & 8 \\
\hline Thailand & & & & & & & \\
\hline Tunisia & & & & & & & \\
\hline Turkey & & & & & & & \\
\hline United Kingdom & & & & & & & \\
\hline United States & 19.361 .098 & 13.553 & 96.805 & 7.497 & 26.989 & 716.242 & 2.198 .843 \\
\hline Uruguay & & & & & & & \\
\hline Zimbabwe & & & & & & & \\
\hline TOTAL & 30.689 .627 & 21.483 & 285.272 & 12.139 & 43.702 & 1.159 .786 & 3.560 .511 \\
\hline
\end{tabular}

Table 7: Calculated annual collector yield and corresponding oil equivalent as well as $\mathrm{CO}_{2}$ reduction of unglazed water collectors in operation by the end of 2010 


\subsection{Annual collector yield by economic region}

\subsubsection{Annual collector yield of glazed water collectors by economic region in $\mathbf{2 0 1 0}$}

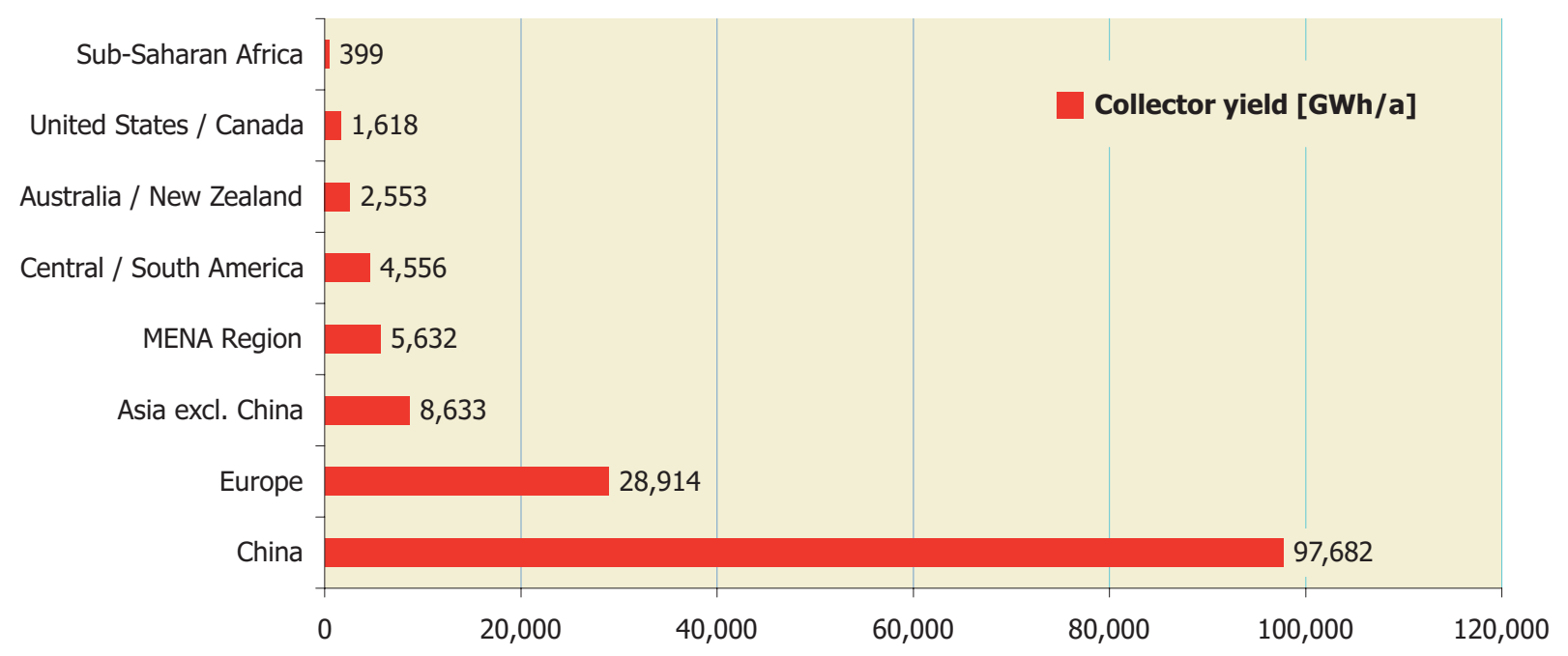

Figure 24: Annual collector yield of glazed (FPC + ETC) water collectors in operation by economic region in 2010

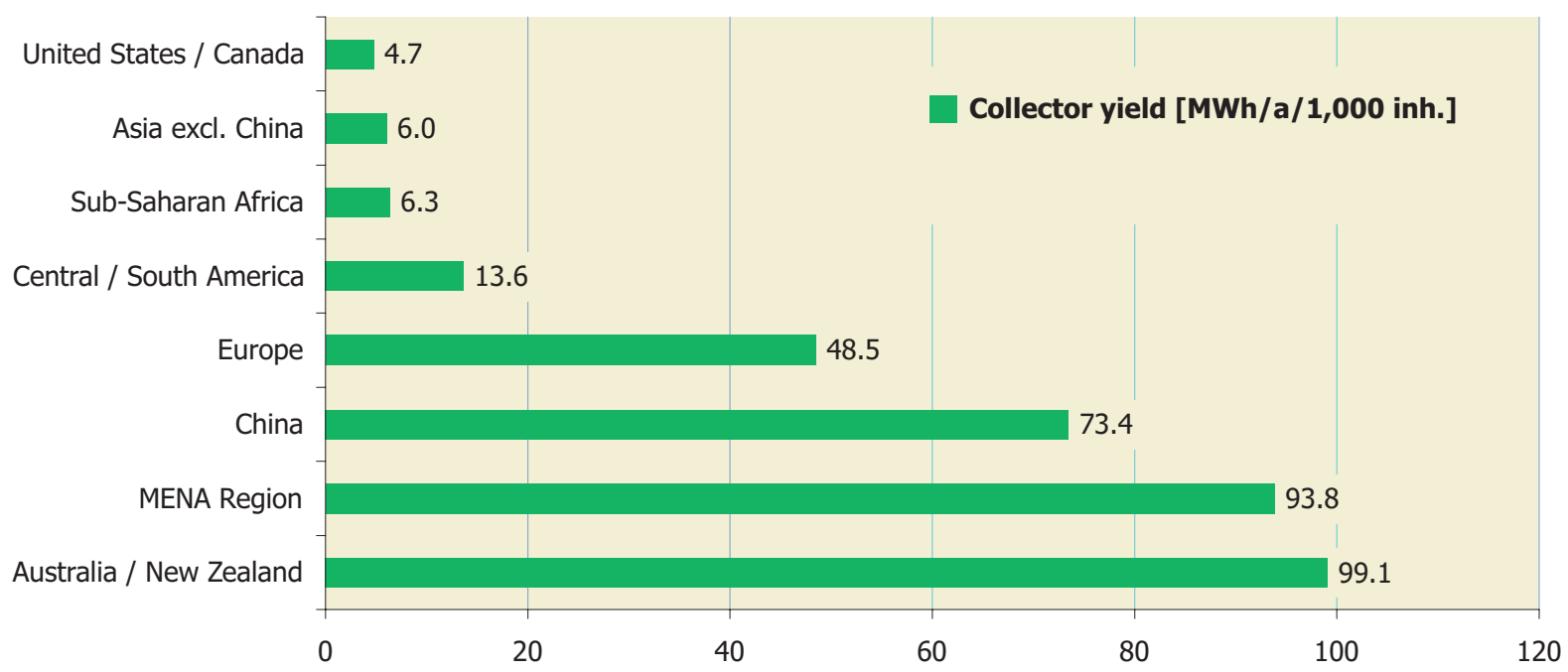

Figure 25: Annual collector yield of glazed (FPC + ETC) water collectors in operation by economic region in MWh per 1,000 inhabitants in 2010

Asia excluding China: Central / South America: Europe: MENA Region: Sub-Saharan Africa:
India, Japan, Korea South, Taiwan, Thailand Barbados, Brazil, Chile, Mexico, Uruguay Albania, EU 27, Macedonia, Norway, Switzerland, Turkey Israel, Jordan, Lebanon, Morocco, Tunisia Namibia, South Africa, Zimbabwe 


\subsubsection{Annual collector yield of unglazed water collectors by economic region in 2010}

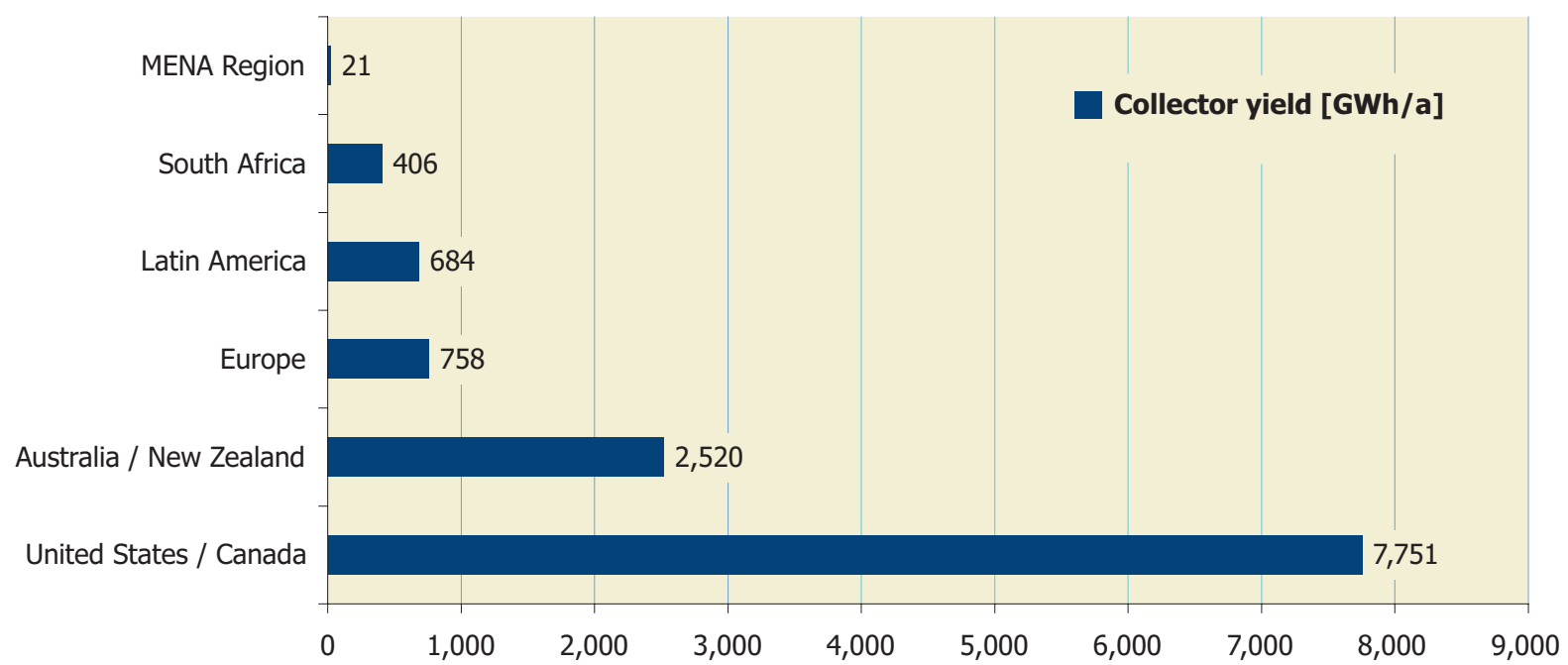

Figure 26: Annual collector yield of unglazed water collectors in operation by economic region in 2010

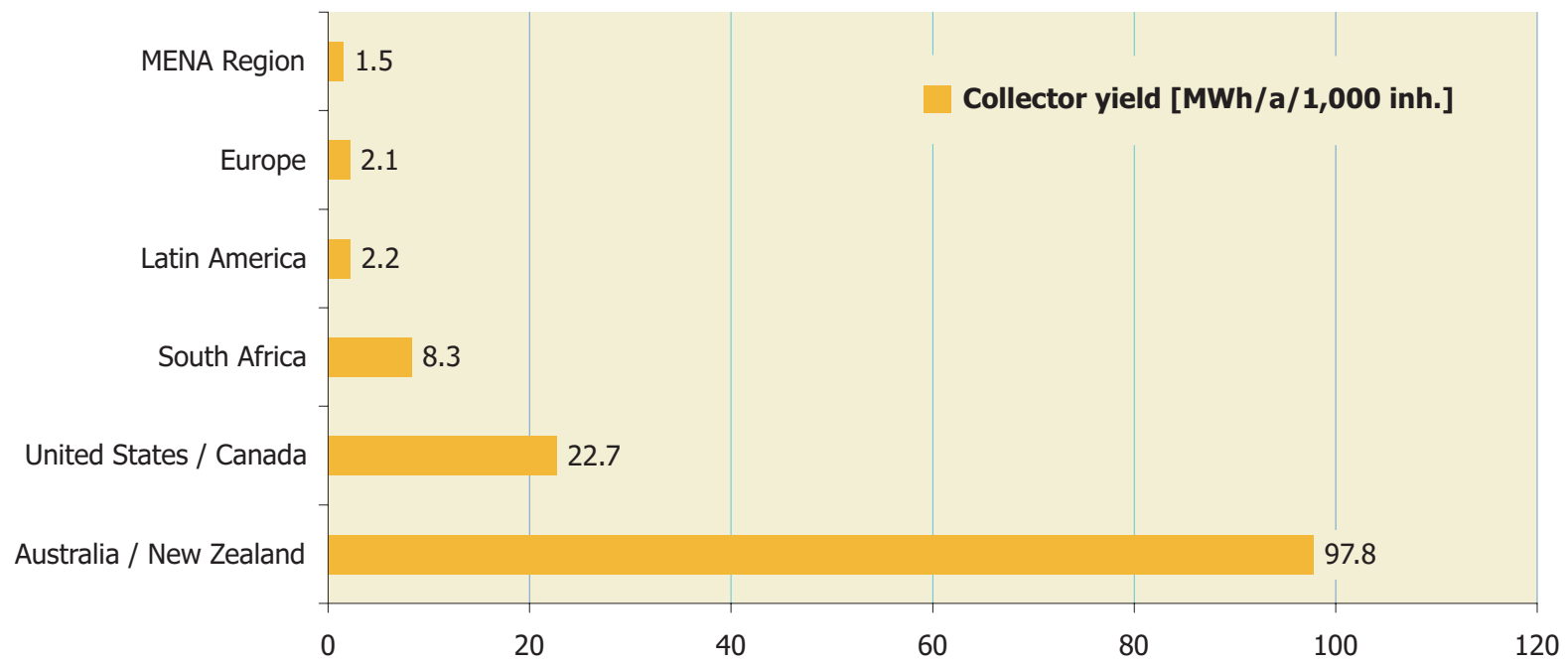

Figure 27: Annual collector yield of unglazed water collectors in operation by economic region in MWh per 1,000 inhabitants in 2010

Latin America: Europe: MENA Region:
Brazil, Mexico

EU 16, Norway, Switzerland

Israel, Jordan 


\subsection{Annual energy savings by economic region}

\subsubsection{Annual energy savings in oil equivalents by glazed water collectors by economic region in 2010}

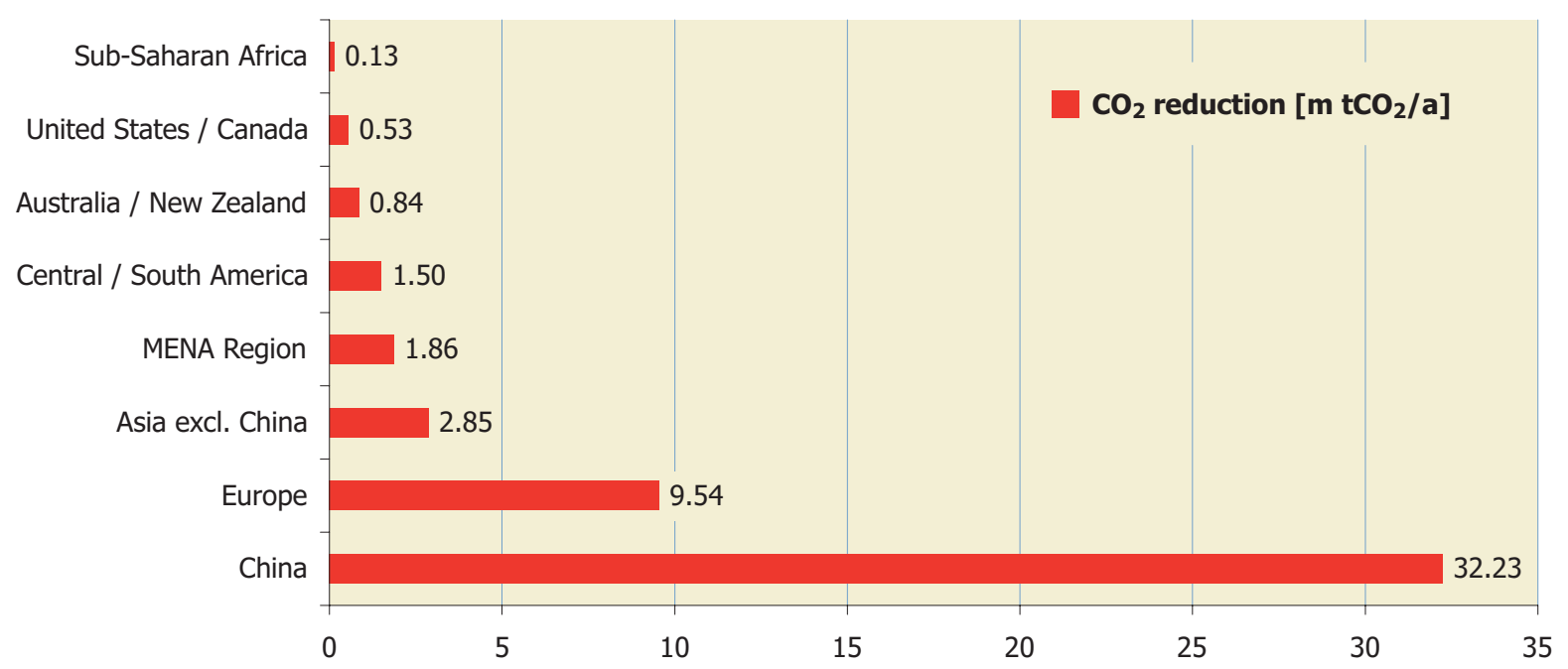

Figure 28: Annual energy savings in oil equivalent by glazed (FPC + ETC) water collectors in operation by economic region in 2010

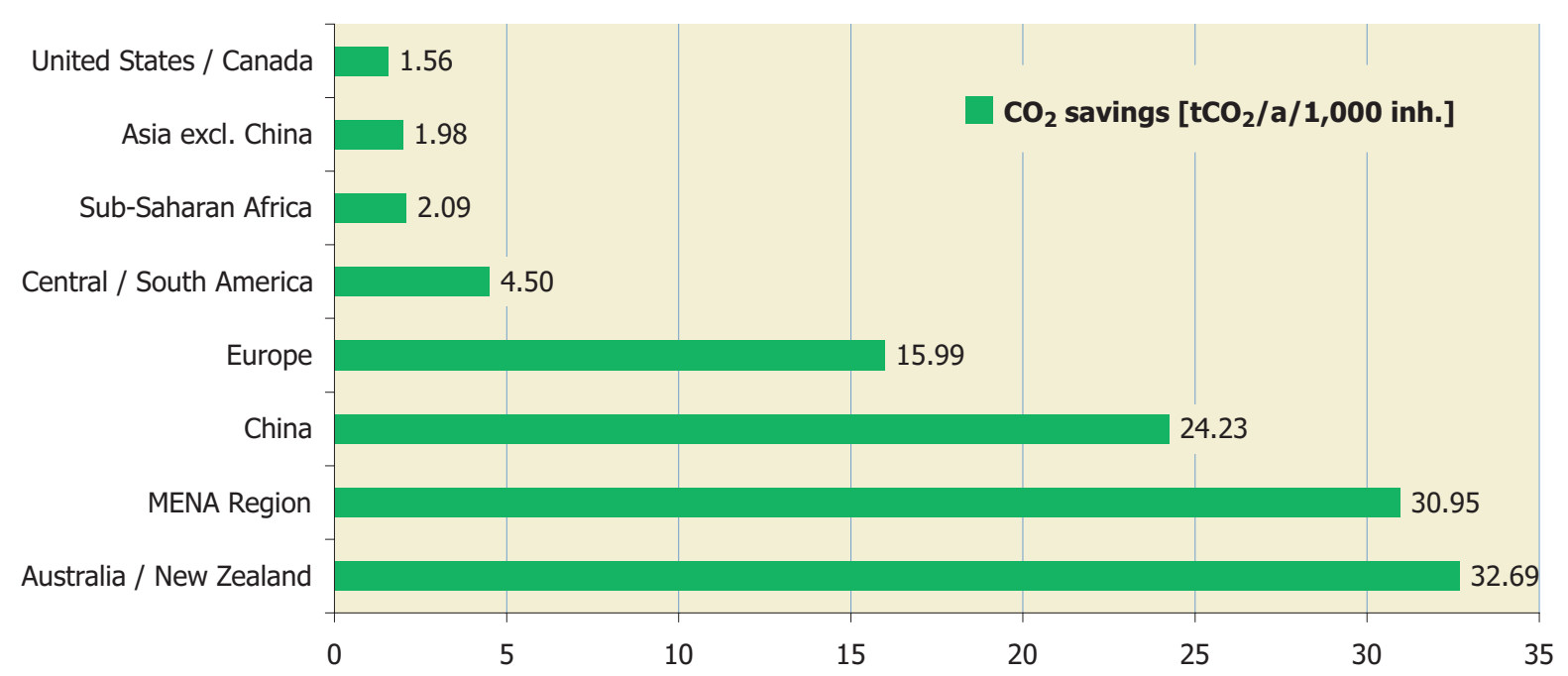

Figure 29: Annual energy savings in oil equivalent by glazed (FPC + ETC) water collectors in operation by economic region per 1,000 inhabitants in 2010

Asia excluding China: Central / South America: Europe:

MENA Region:

Sub-Saharan Africa:
India, Japan, Korea South, Taiwan, Thailand Barbados, Brazil, Chile, Mexico, Uruguay Albania, EU 27, Macedonia, Norway, Switzerland, Turkey Israel, Jordan, Lebanon, Morocco, Tunisia Namibia, South Africa, Zimbabwe 
5.2.2 Annual energy savings in oil equivalents by unglazed water collectors by economic region in 2010

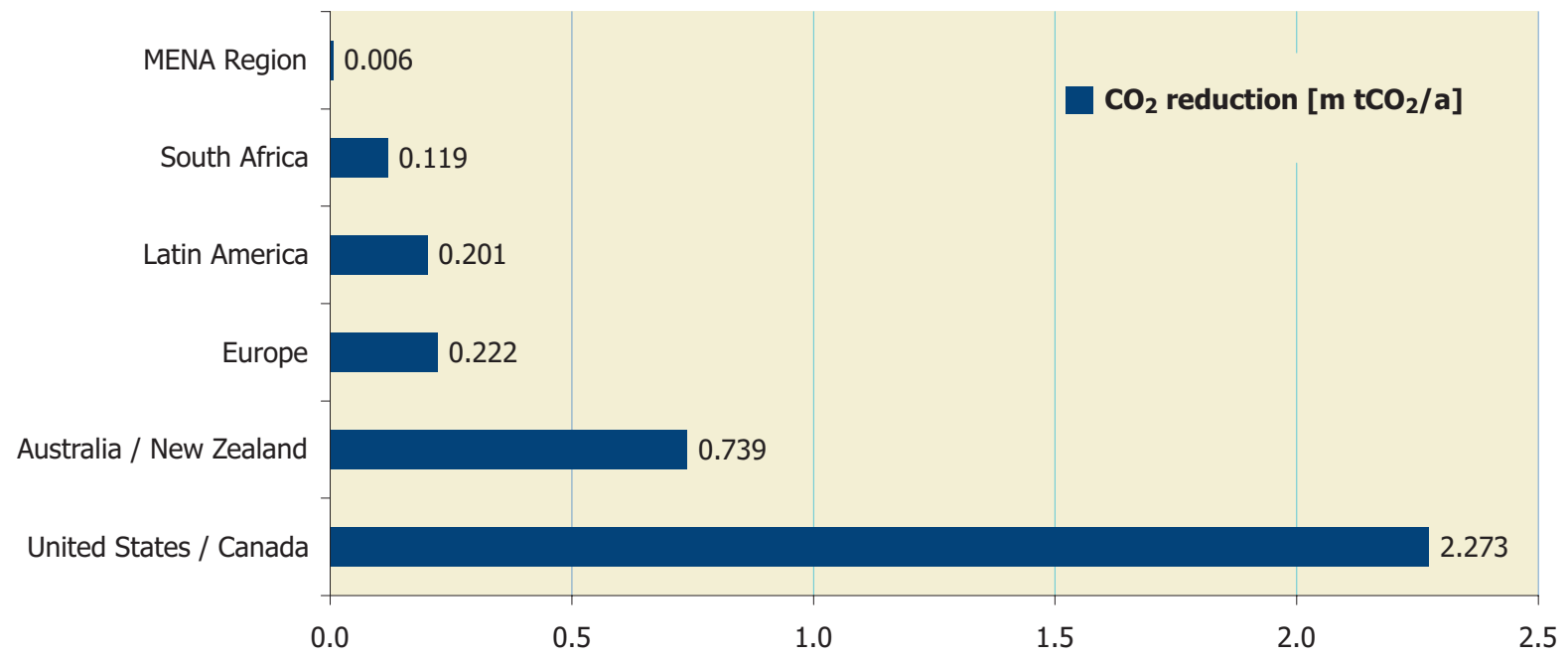

Figure 30: Annual energy savings in oil equivalents by unglazed water collectors in operation by economic region in 2010

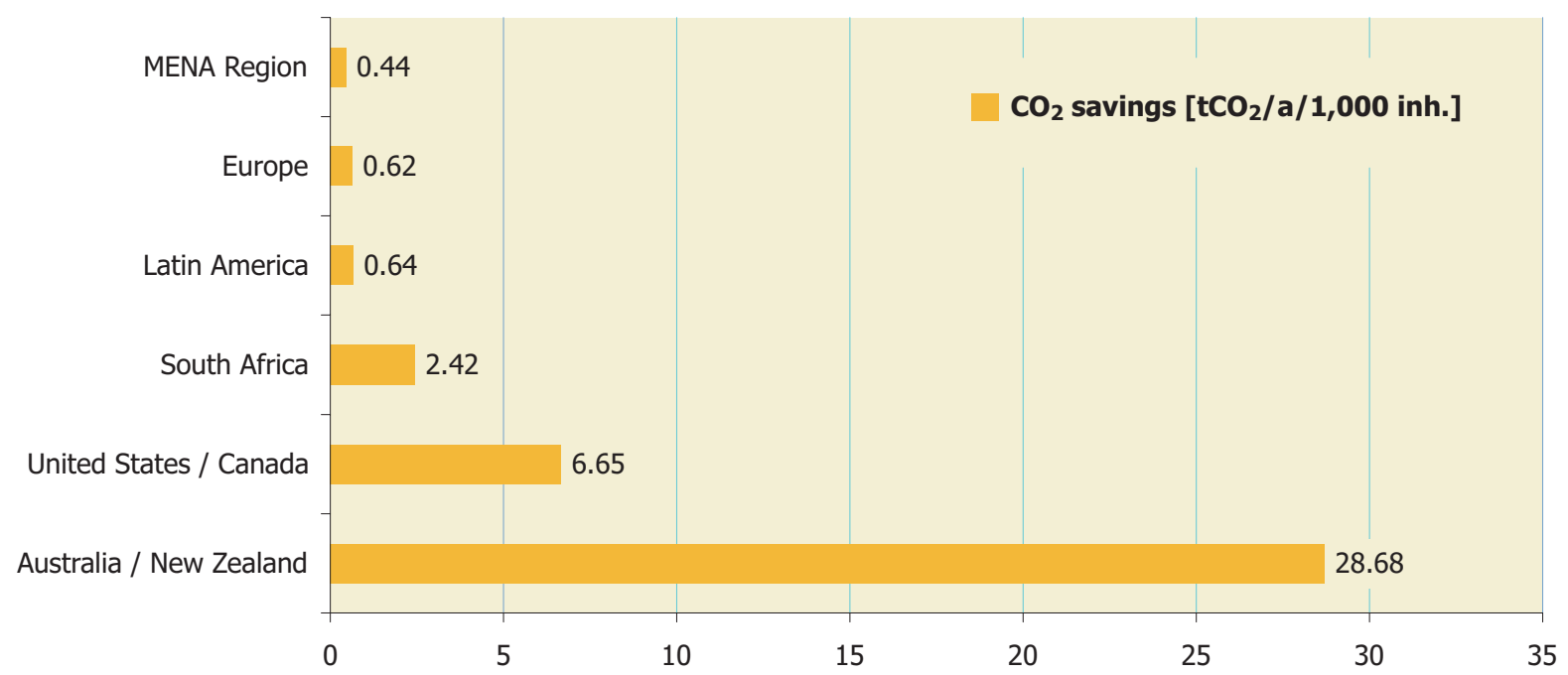

Figure 31: Annual energy savings in oil equivalent by unglazed water collectors in operation by economic region per 1,000 inhabitants in 2010

Latin America: Europe: MENA Region:
Brazil, Mexico

EU 16, Norway, Switzerland

Israel, Jordan 


\subsection{Annual contribution to $\mathrm{CO}_{2}$ reduction by economic region}

\subsubsection{Annual $\mathrm{CO}_{2}$ reduction by glazed water collectors and economic region in $\mathbf{2 0 1 0}$}

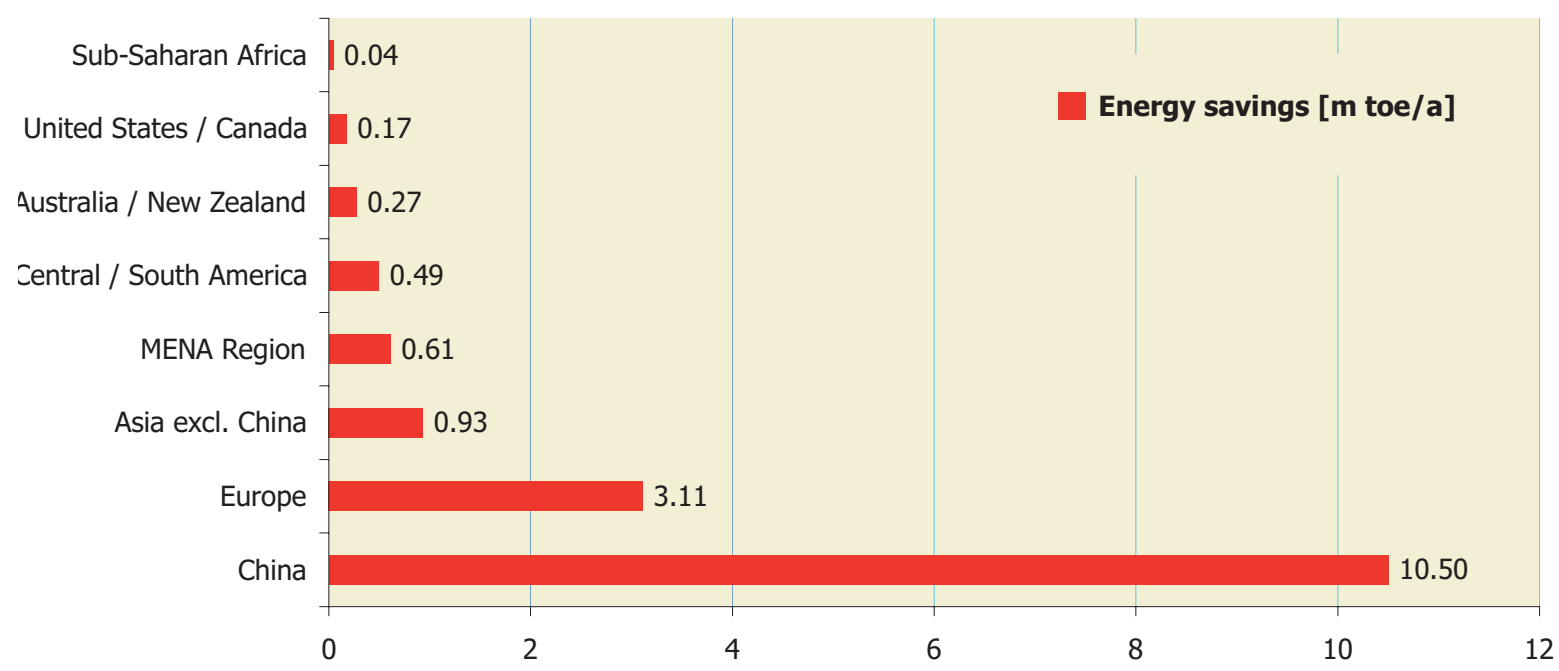

Figure 32: Contribution to $\mathrm{CO}_{2}$ reduction by glazed (FPC $+\mathrm{ETC}$ ) water collectors in operation by economic region in 2010

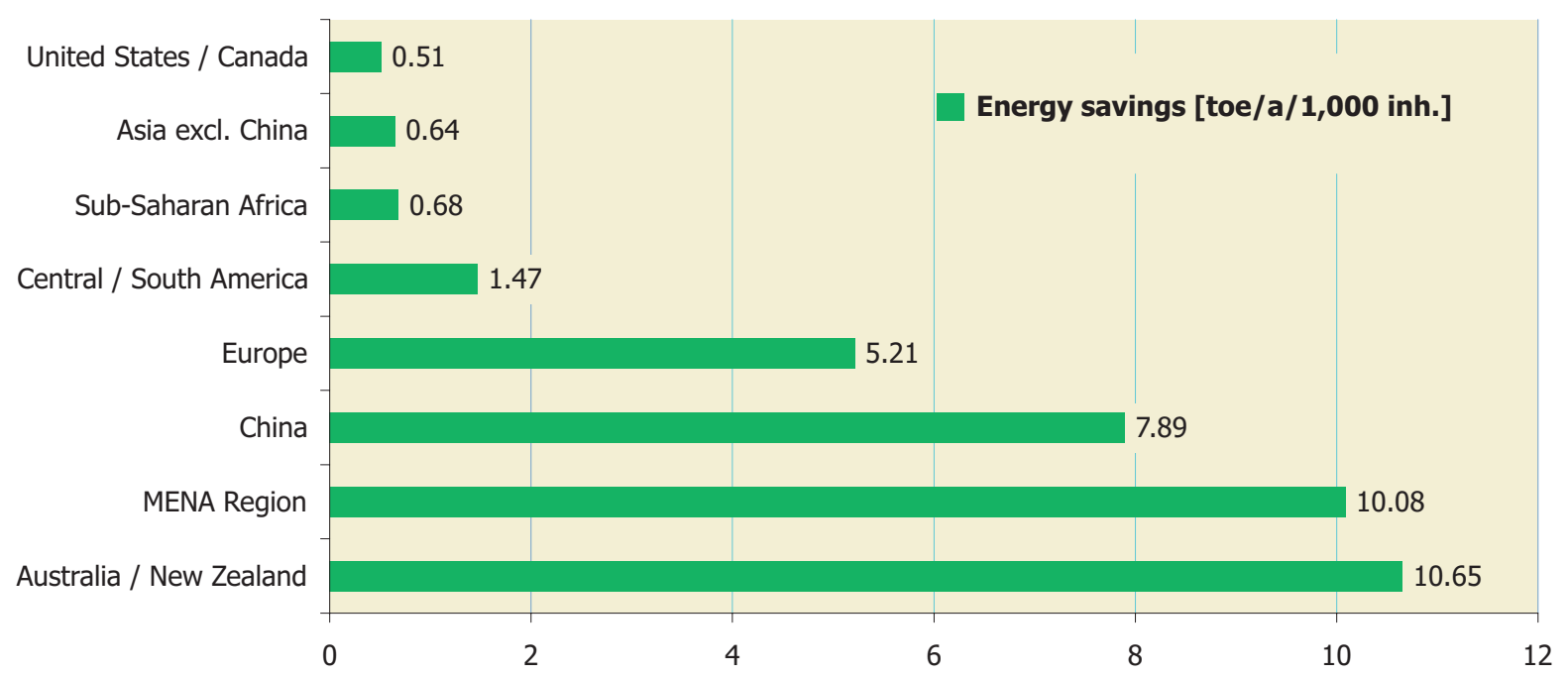

Figure 33: Contribution to $\mathrm{CO}_{2}$ reduction by glazed (FPC + ETC) water collectors in operation by economic region per 1,000 inhabitants in 2010

Asia excluding China: Central / South America: Europe:

MENA Region:

Sub-Saharan Africa:
India, Japan, Korea South, Taiwan, Thailand Barbados, Brazil, Chile, Mexico, Uruguay Albania, EU 27, Macedonia, Norway, Switzerland, Turkey Israel, Jordan, Lebanon, Morocco, Tunisia Namibia, South Africa, Zimbabwe 


\subsubsection{Annual $\mathrm{CO}_{2}$ reduction by unglazed water collectors and economic region in $\mathbf{2 0 1 0}$}

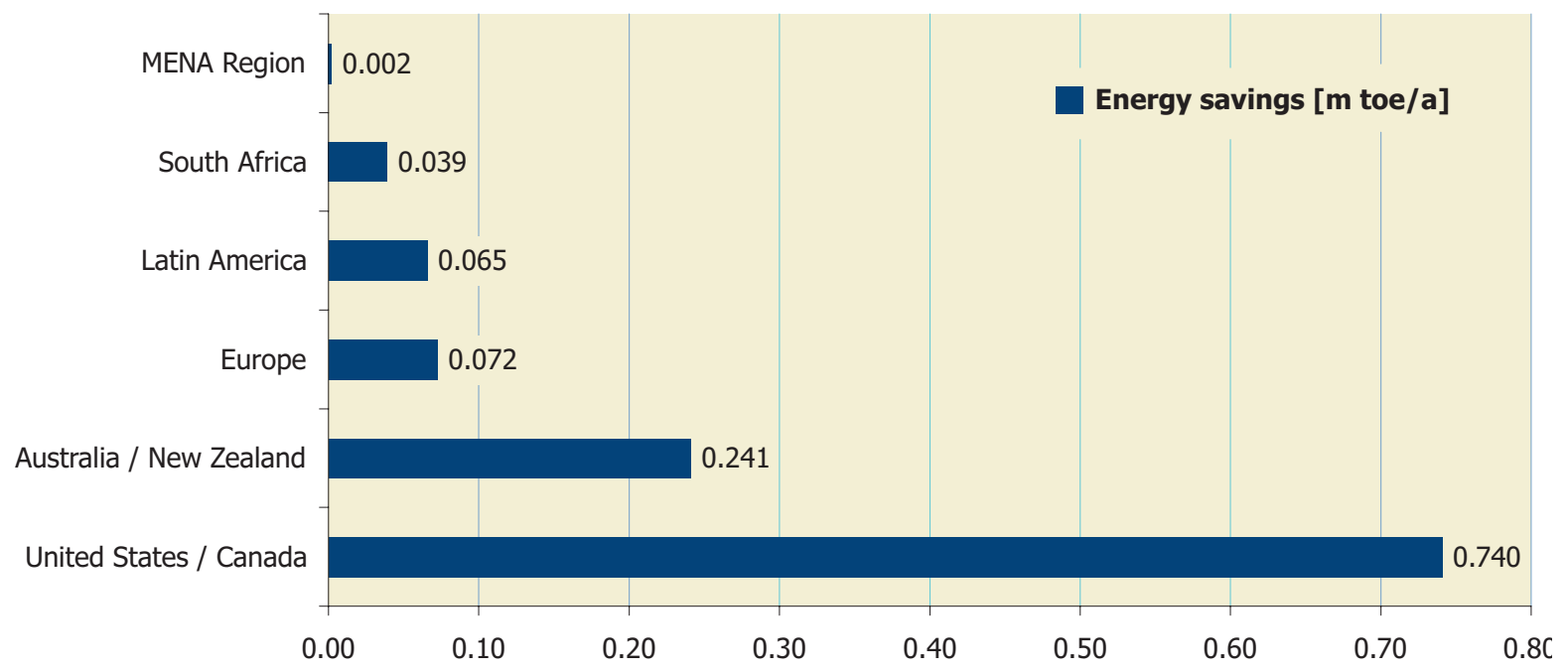

Figure 34: Contribution to $\mathrm{CO}_{2}$ reduction by unglazed water collectors in operation by economic region in $\mathbf{2 0 1 0}$

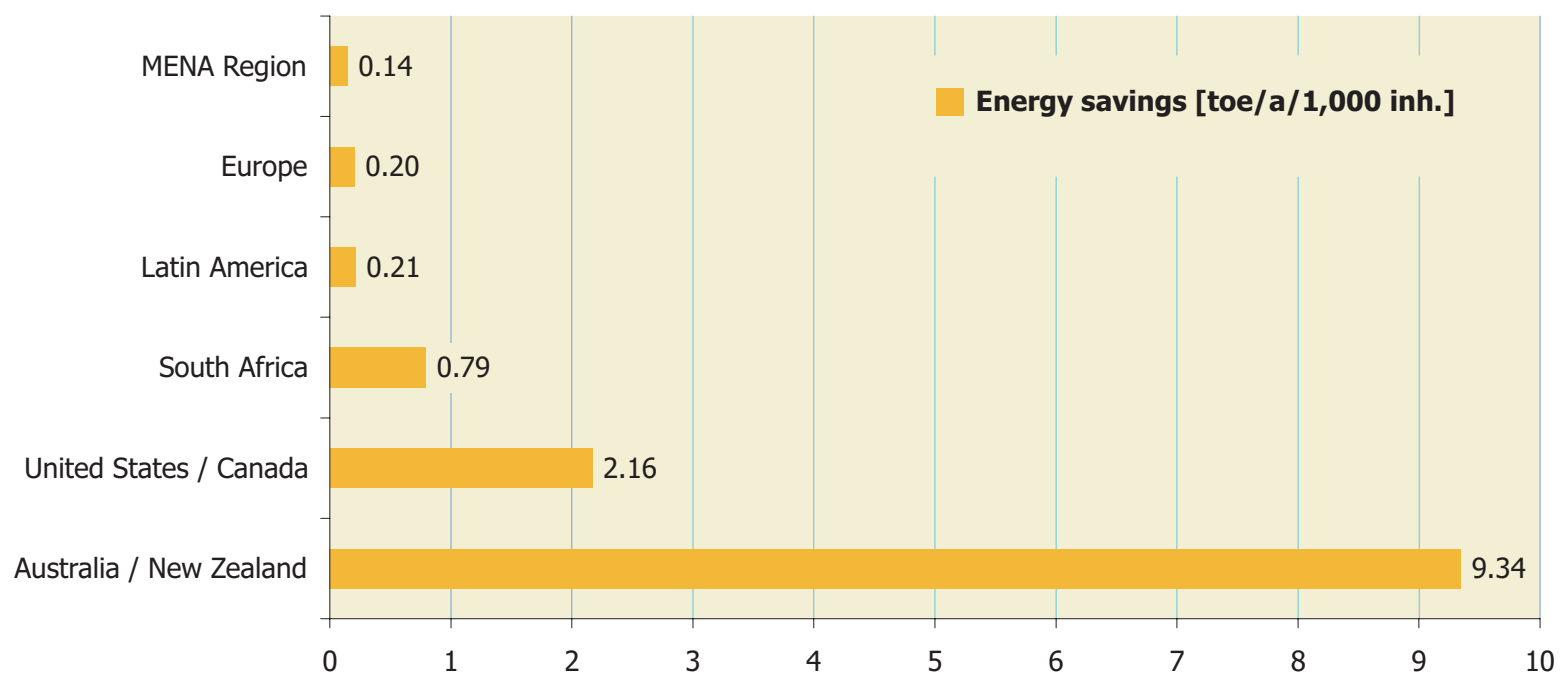

Figure 35: Contribution to $\mathrm{CO}_{2}$ reduction by unglazed water collectors in operation by economic region per 1,000 inhabitants in 2010

$\begin{array}{ll}\text { Latin America: } & \text { Brazil, Mexico } \\ \text { Europe: } & \text { EU 16, Norway, Switzerland } \\ \text { MENA Region: } & \text { Israel, Jordan }\end{array}$




\section{Distribution of systems by system type and application}

The thermal utilization of the energy from the sun greatly varies in different regions on Earth. It can be roughly distinguished between the type of solar thermal collector used, the way of system operation (pumped solar thermal system or thermosiphon systems) as well as the main application the energy gained from the sun is used for (hot water preparation, space heating, industrial processes, cooling).

In chapters 6.1 to 6.6 , these system types and applications are shown by different economic regions for both the cumulated capacity in operation and the newly installed capacity in 2010. Finally in chapters 6.7 to 6.9 , an overview on large scale solar heating and cooling applications in Europe and worldwide is given.

\subsection{Distribution by type of solar thermal collector of the total installed capacity}

Referring to the total water collector area, evacuated tube collectors dominated with a share of $57 \%$ of the cumulated capacity in operation (see Figure 36) and a share of $78 \%$ of the newly installed capacity (see Figure 38). Especially in China, vacuum tube collectors played an important role and since this was by far the largest market supported by high growth rates, the worldwide figures tend towards a higher share of this type of solar thermal collector.

Unglazed water collectors accounted for $11 \%$ of the cumulated water collectors installed worldwide (see Figure 36) and the share tended to decrease: in 2010 the share of unglazed water collectors was just slightly higher than $4 \%$ of the newly installed capacity (see Figure 38).

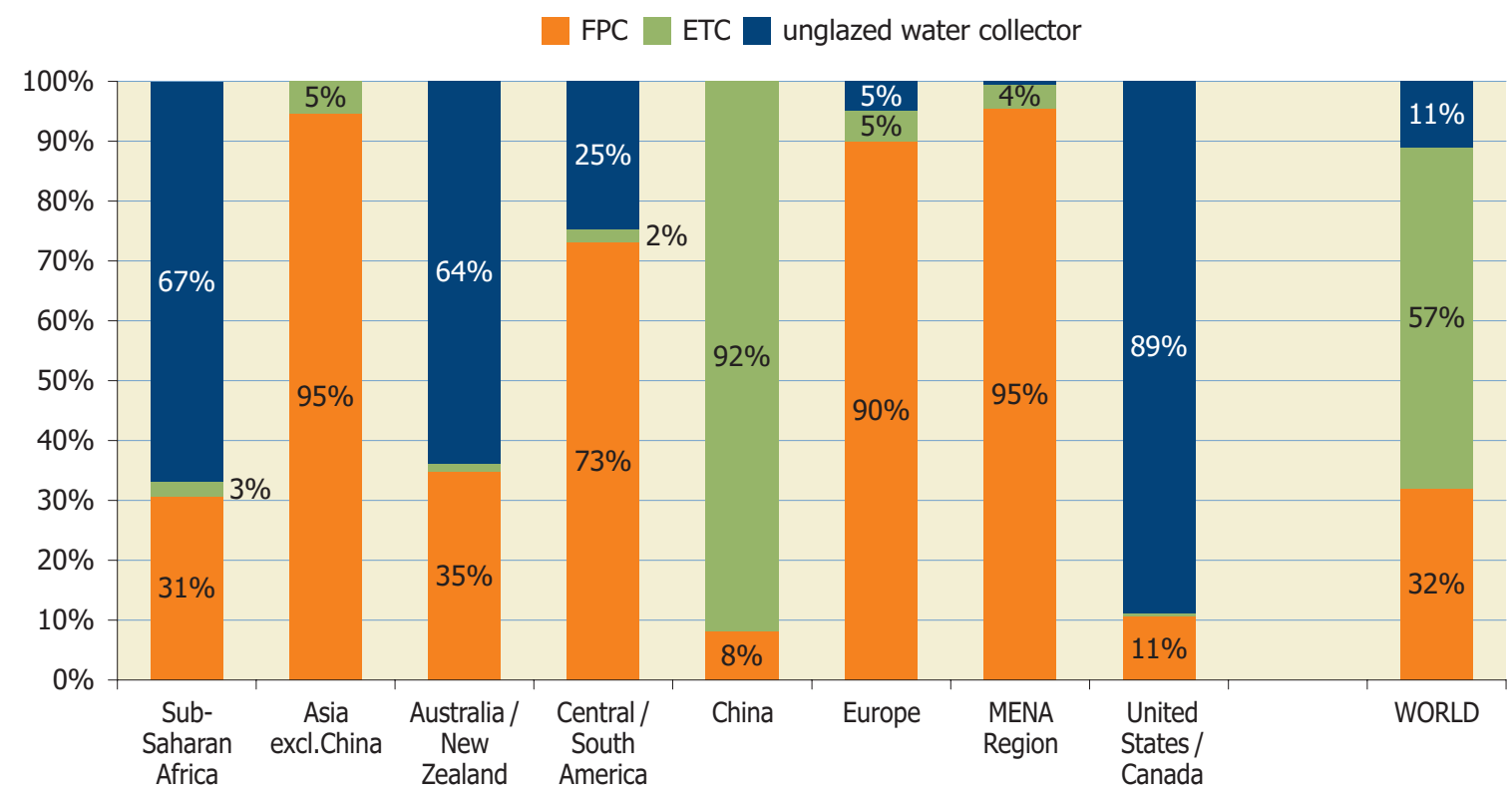

Figure 36: Distribution by type of solar thermal collector for the total installed water collector capacity in operation by the end of 2010 
FPC ETC

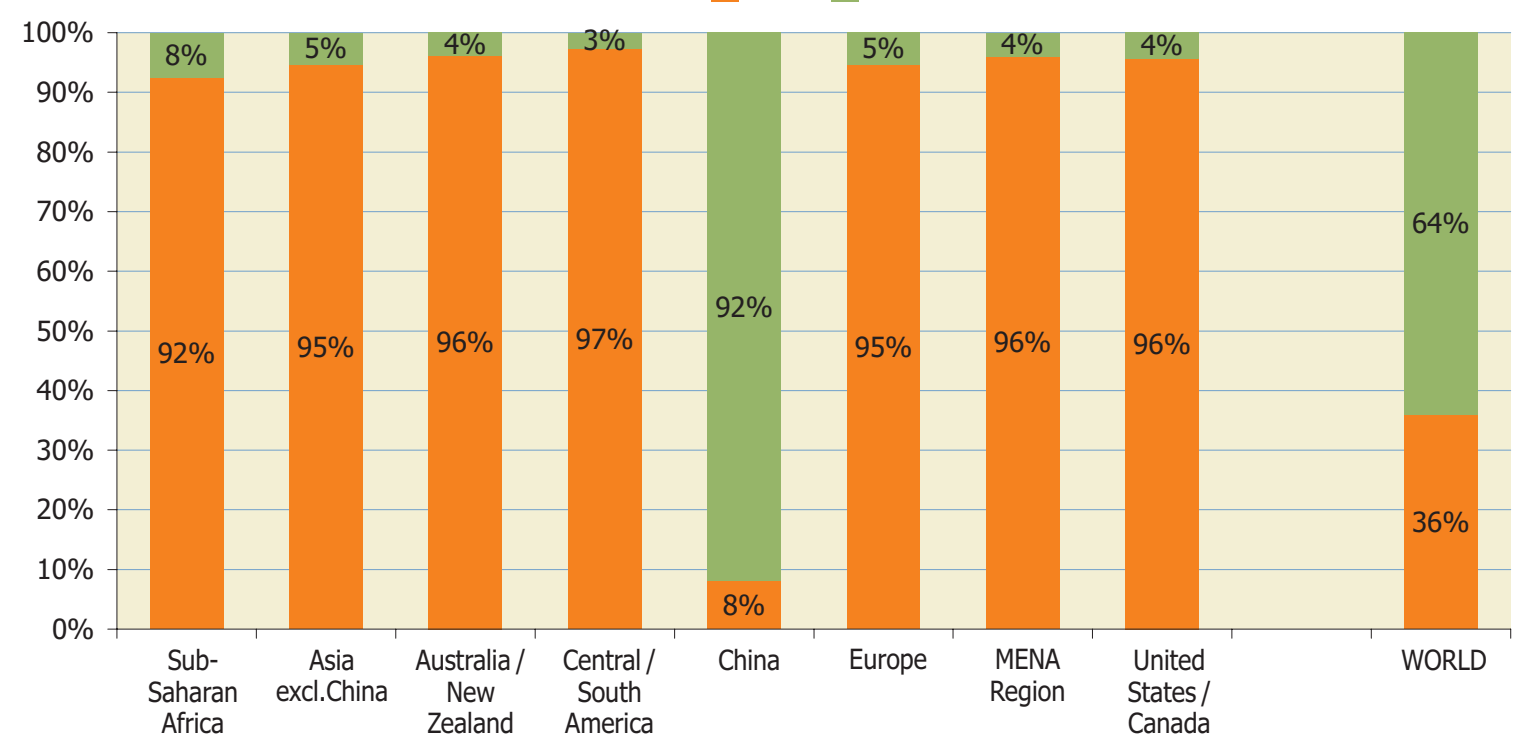

Figure 37: Distribution by type of solar thermal collector for the total installed glazed (FPC + ETC) water collector capacity in operation by the end of 2010

Asia excluding China: Central / South America:

Europe:

MENA Region:

Sub-Saharan Africa:
India, Japan, Korea South, Taiwan, Thailand

Barbados, Brazil, Chile, Mexico, Uruguay

Albania, EU 27, Macedonia, Norway, Switzerland, Turkey

Israel, Jordan, Lebanon, Morocco, Tunisia

Namibia, South Africa, Zimbabwe 


\subsection{Distribution by type of solar thermal collector of the newly installed capacity in $\mathbf{2 0 1 0}$}

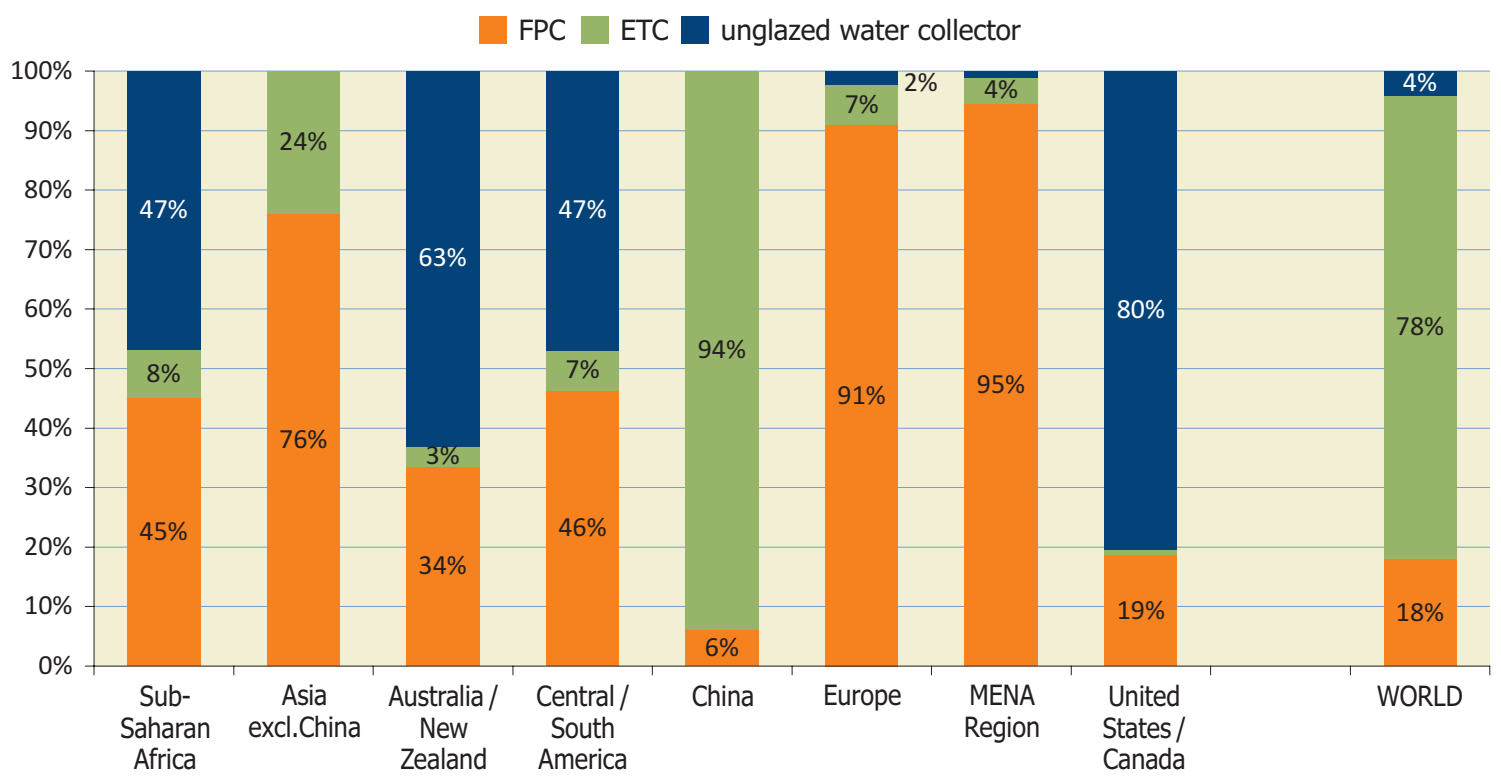

Figure 38: Distribution by type of solar thermal collector

for the newly installed water collector capacity in 2010

FPC $\square$ ETC

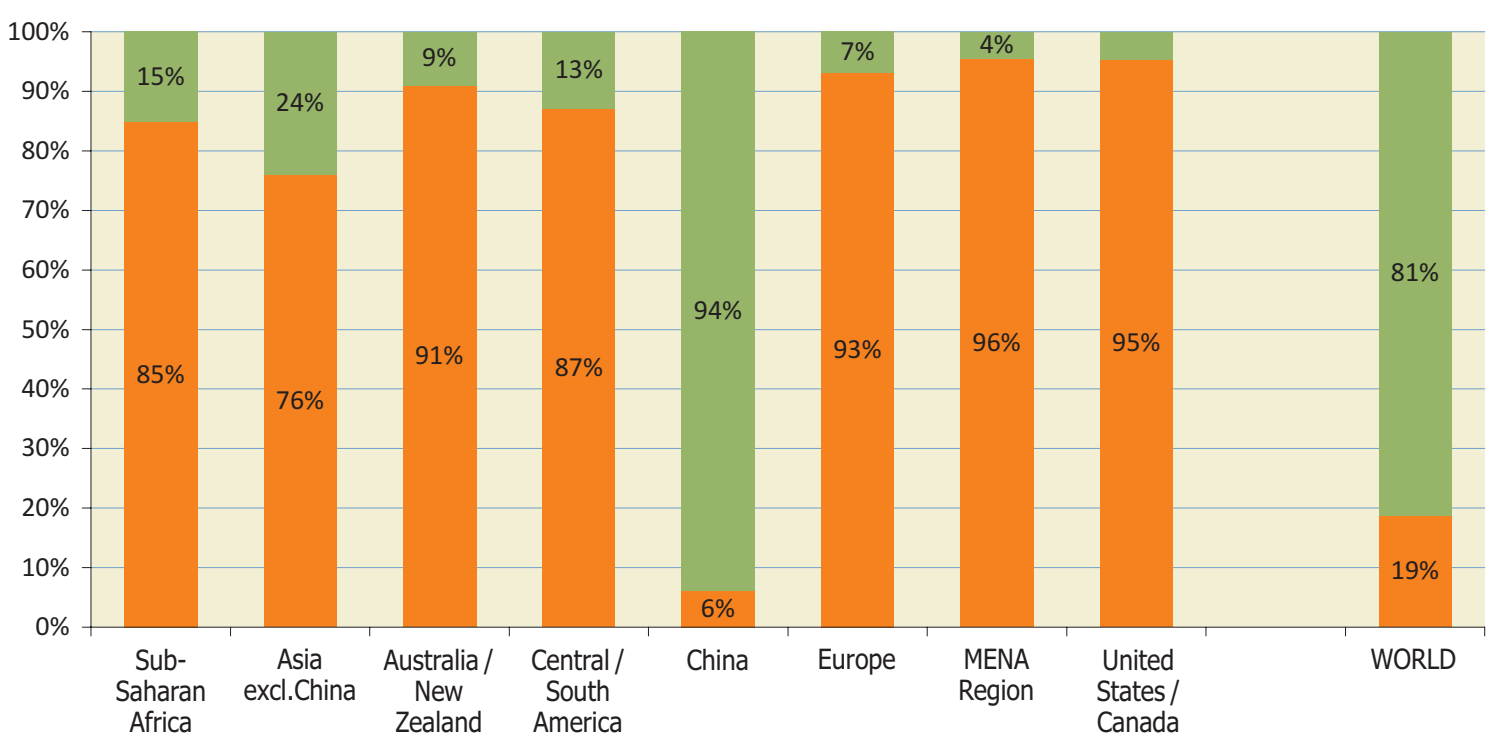

Figure 39: Distribution by type of solar thermal collector for the newly installed glazed (FPC + ETC) water collector capacity in 2010

Asia excluding China:

Europe:

India, Japan, Korea South, Taiwan

Latin America:

Albania, EU 27, Norway, Switzerland, Turkey

Brazil, Chile, Mexico

MENA Region:

Israel, Jordan, Morocco, Tunisia

Sub-Saharan Africa:

Namibia, South Africa, Zimbabwe 


\subsection{Distribution by type of system of the total installed capacity}

Worldwide, about three quarters of all solar thermal systems installed are thermosiphon systems and the rest are pumped solar heating systems (see Figure 40). Similar to the distribution by type of solar thermal collector in total numbers the Chinese market influenced the overall figures most, and in 2010 89\% of the newly installed systems were estimated to be thermosiphon systems while pumped systems only accounted for $11 \%$ (see Figure 41).

In general, thermosiphon systems are more common in warm climates such as in Africa, Latin America, South of Europe and the MENA region. In these regions thermosiphon systems are more often equipped with flat plate collectors while in China the typical thermosiphon system for domestic hot water preparation is equipped with evacuated tubes.

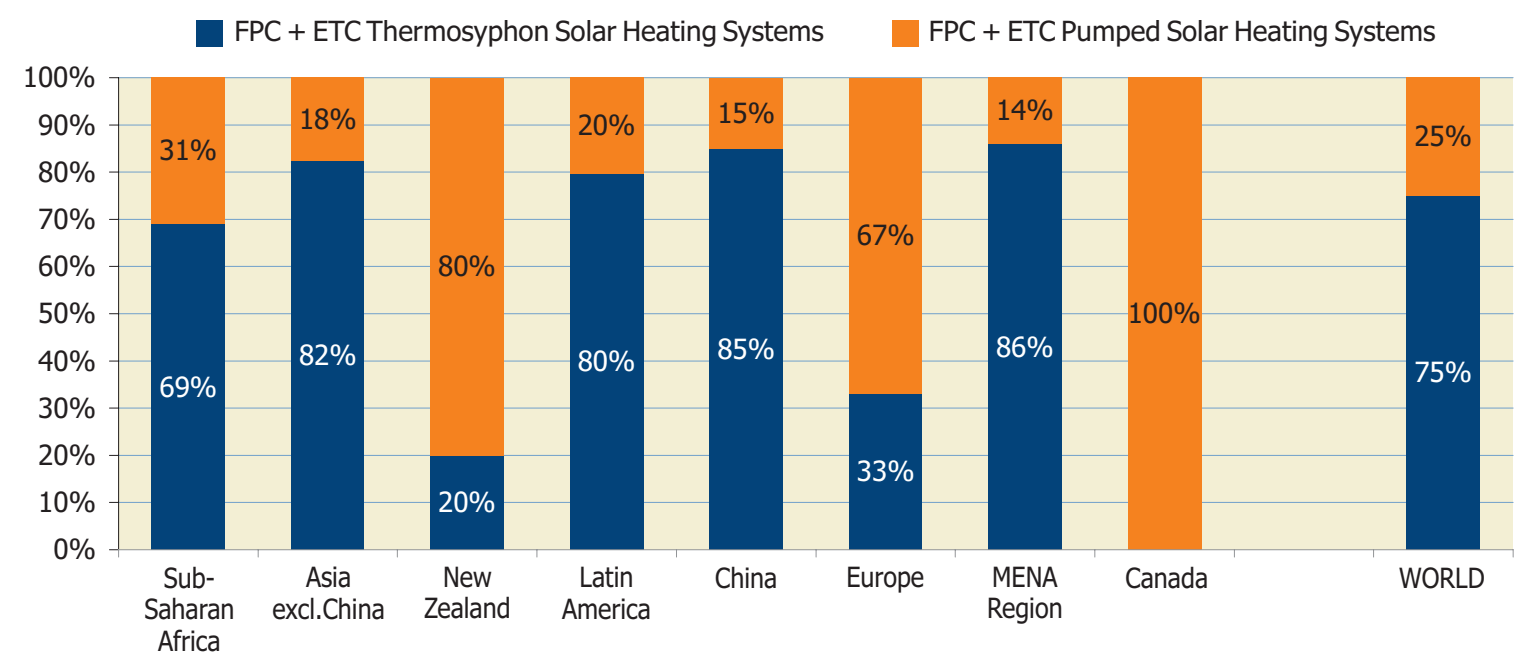

Figure 40: Distribution by type of system for the total installed water collector capacity in operation by the end of 2010

Asia excluding China: Japan, Korea South, Taiwan Latin America: Brazil, Chile

Europe: $\quad$ Albania, EU 19, Norway, Switzerland, Turkey Sub-Saharan Africa: Namibia, South Africa MENA Region: Jordan, Tunisia

\subsection{Distribution by type of system of the newly installed capacity in $\mathbf{2 0 1 0}$}

FPC + ETC Thermosyphon Solar Heating Systems

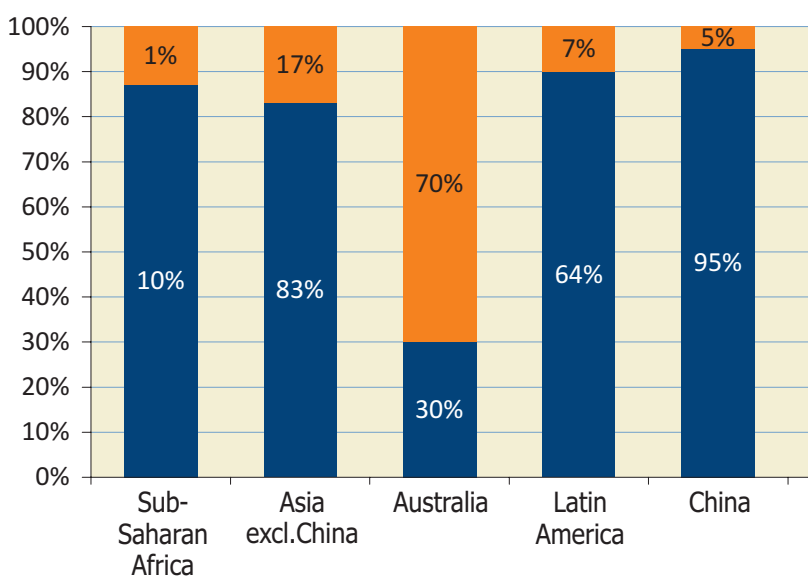

FPC + ETC Pumped Solar Heating Systems

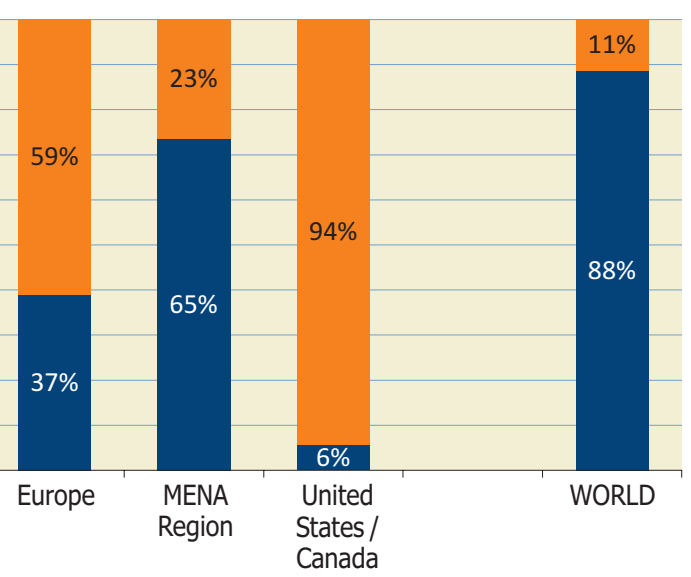

Figure 41: Distribution by type of system for the newly installed water collector capacity in 2010
Asia excluding China:
Latin America:
India, Japan, Korea South, Taiwan
Brazil
Sub-Saharan Africa:
Namibia 


\subsection{Distribution by application of the total installed capacity ${ }^{5}$}

The calculated number of different types of solar thermal systems in operation exceeded 53 million by the end of 2010 (see Table 5). Worldwide, 85\% of the overall capacity installed was used for domestic hot water preparation in single family houses and $10 \%$ were attached to larger domestic hot water consumers such as multifamily houses, hotels, hospitals, schools, homes for elderly people, etc. (see Figure 42).

The market for solar combi systems (systems that deliver energy for both domestic hot water and space heating) is well established in some mature European markets such as in Germany and Austria accounting for more than $40 \%$ in these local markets and for 4\% in a worldwide context (see Figure 43).

Other applications such as solar supported district heating networks, solar process heat and solar air conditioning systems are at a very early stage of market penetration in a worldwide context amounting for less than $1 \%$ of the total installed capacity.

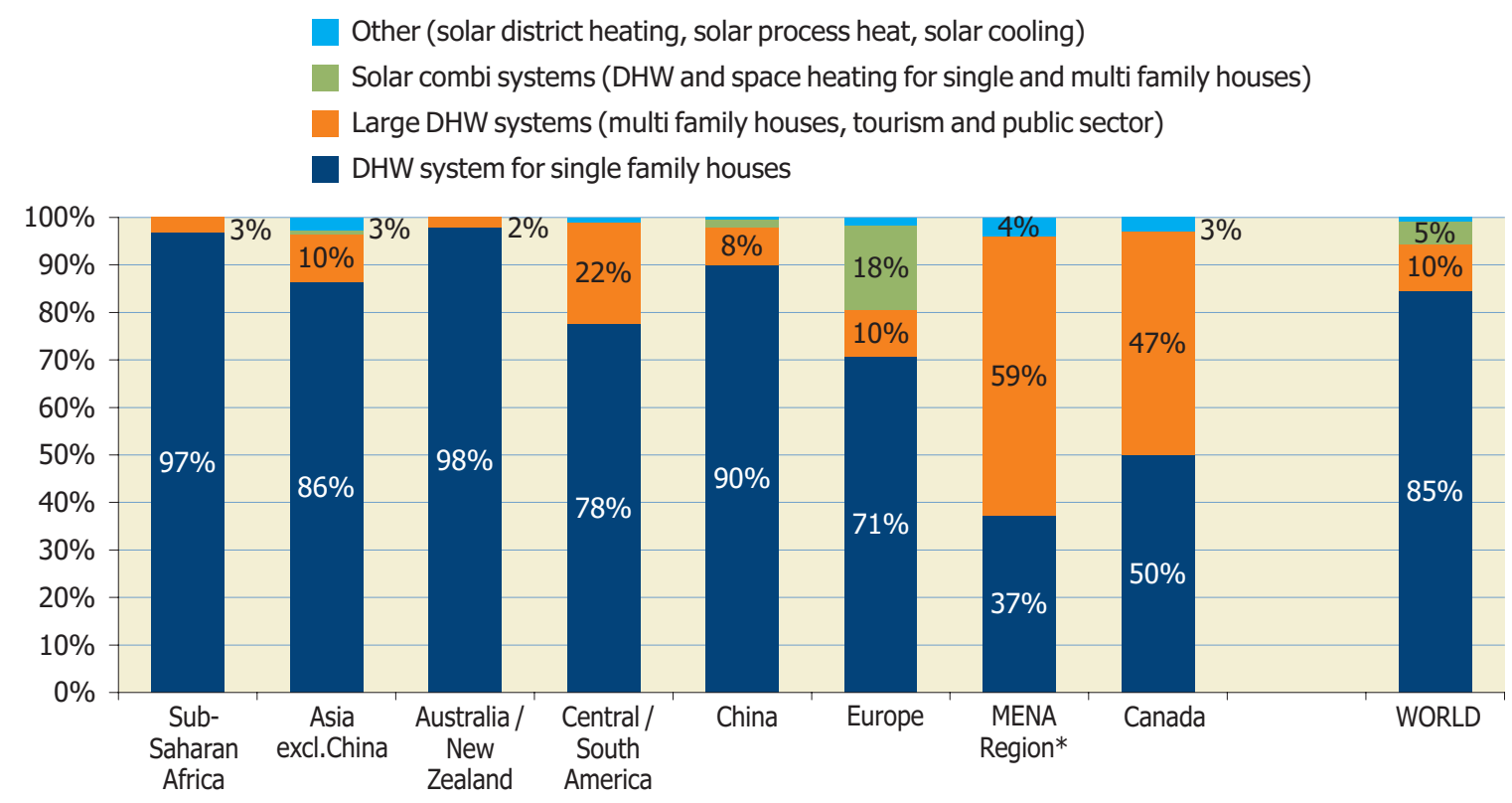

Figure 42: Distribution of solar thermal systems by application for the total installed glazed water collector capacity in operation by the end of 2010

$\begin{array}{ll}\text { DHW } & \text { Domestic hot water } \\ \text { Asia excluding China: } & \text { India, Japan, Korea South, Taiwan } \\ \text { Central / South America: } & \text { Barbados, Brazil, Chile, Mexico } \\ \text { Europe: } & \text { Albania, EU 27, Macedonia, Norway, Switzerland, Turkey } \\ \text { MENA Region: } & \text { Israel, Jordan } \\ \text { Sub-Saharan Africa: } & \text { Namibia, South Africa }\end{array}$

5 In the MENA region (especially in Israel) but also in China, it is very common to equip multifamily houses with thermosiphon systems for domestic hot water preparation. A typical system is connected to one flat. By contrast in many European countries large pumped DHW systems in multifamily houses supply DHW or both DHW and space heating to the entire building. When interpreting the figures in chapter 6.5 this has to be considered. 
Other (solar district heating, solar process heat, solar cooling)

Solar combi systems (DHW and space heating for single and multi family houses)

Large DHW systems (multi family houses, tourism and public sector)

DHW system for single family houses

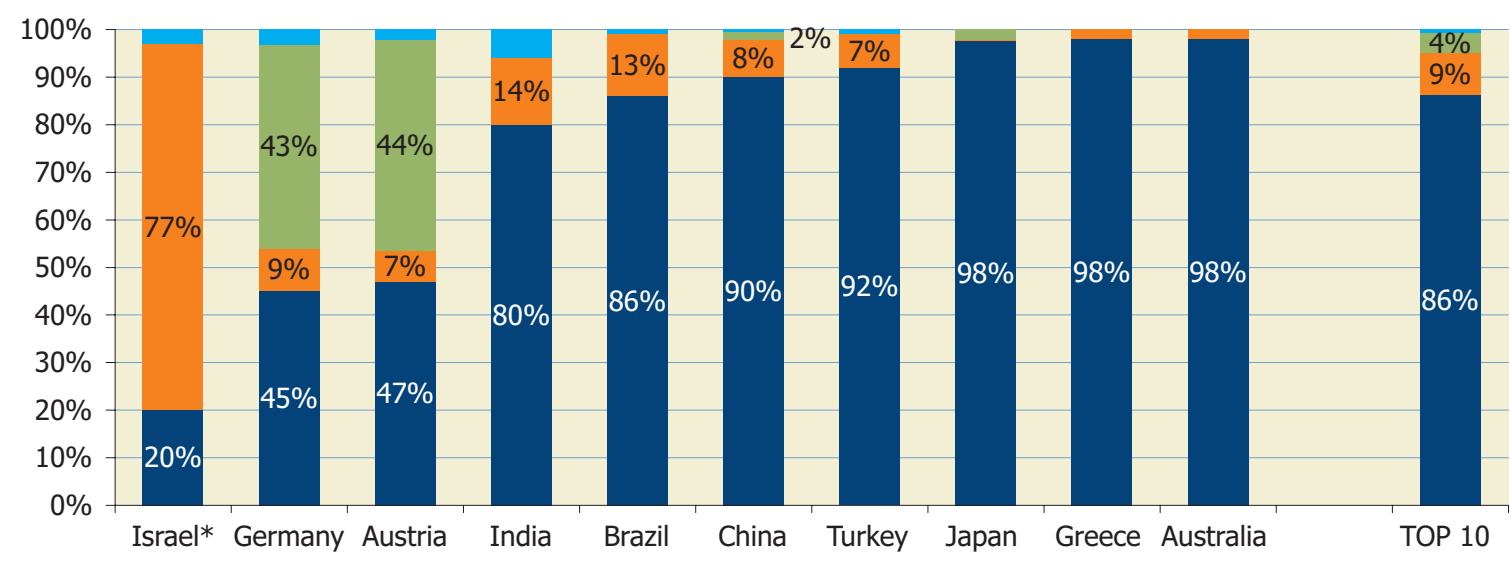

Figure 43: Distribution of solar thermal systems by application for the 10 leading markets of the total installed glazed water collector capacity in operation by the end of 2010 


\subsection{Distribution by application of the newly installed capacity in $2010^{6}$}

For newly installed systems the trend is towards more sophisticated applications with regional focus areas as can be seen in Figure 44, Figure 45 and Figure 46.

Other (solar district heating, solar process heat, solar cooling)

Solar combi systems (DHW and space heating for single and multi family houses)

Large DHW systems (multi family houses, tourism and public sector)

DHW system for single family houses

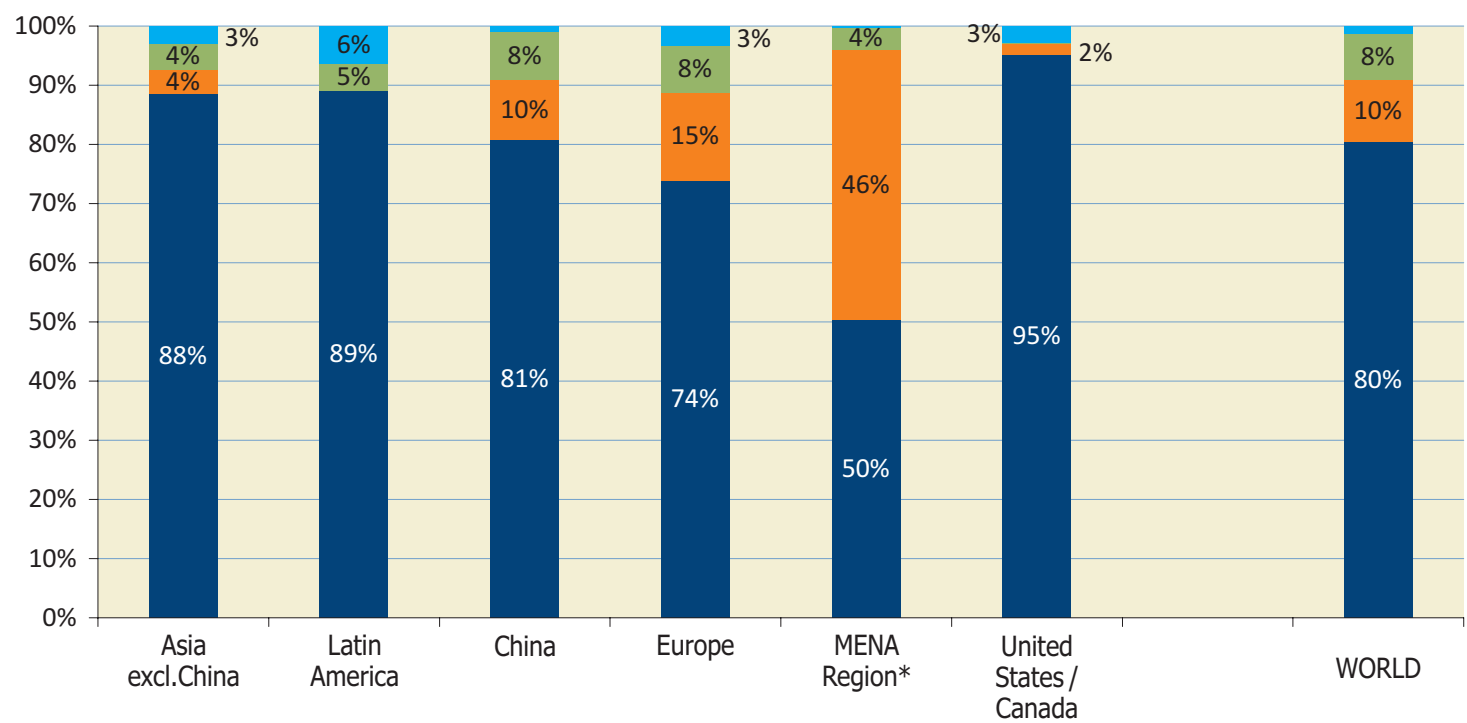

Figure 44: Distribution of different applications of the newly installed capacity of glazed water collectors by economic region in 2010

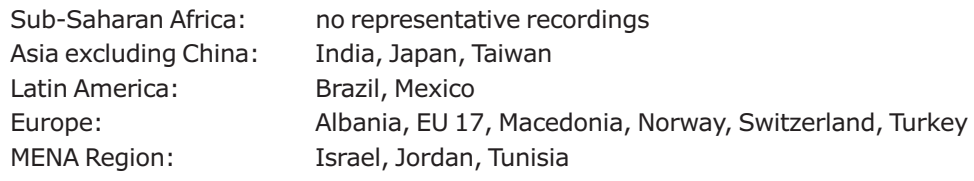

In several well-established markets in Europe as well as in some Latin American (Brazil, Mexico) and Asian (China, India, Japan) countries, the market penetration of solar combi-systems, solar supported district heating networks, industrial applications and solar cooling systems is increasing.

\footnotetext{
6 In the MENA region (especially in Israel) but also in China, it is very common to equip multifamily houses with thermosiphon systems for domestic hot water preparation. A typical system is connected to one flat. By contrast in many European countries large pumped DHW systems in multifamily houses supply DHW or both DHW and space heating to the entire building. When interpreting the figures in chapter 6.6 this has to be considered.
} 


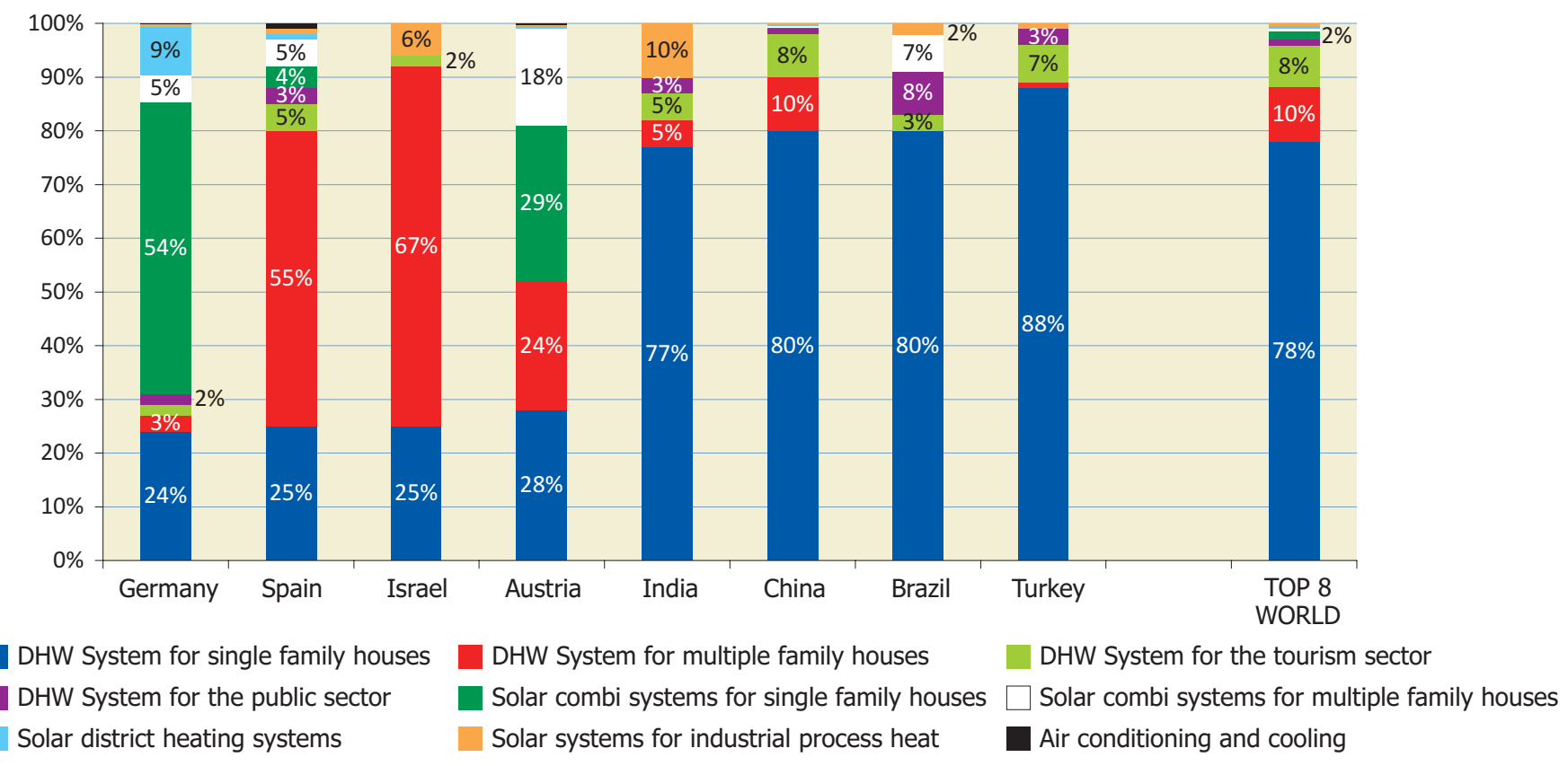

Figure 45: Distribution of different applications of the newly installed capacity

of glazed water collectors for the 8 leading countries worldwide in 2010

Germany, Spain and Austria have the most sophisticated markets for different solar thermal applications. They include systems for hot water preparation, systems for space heating of single- and multifamily houses and hotels, large-scale plants for district heating as well as a growing number of systems for air conditioning, cooling and industrial applications.

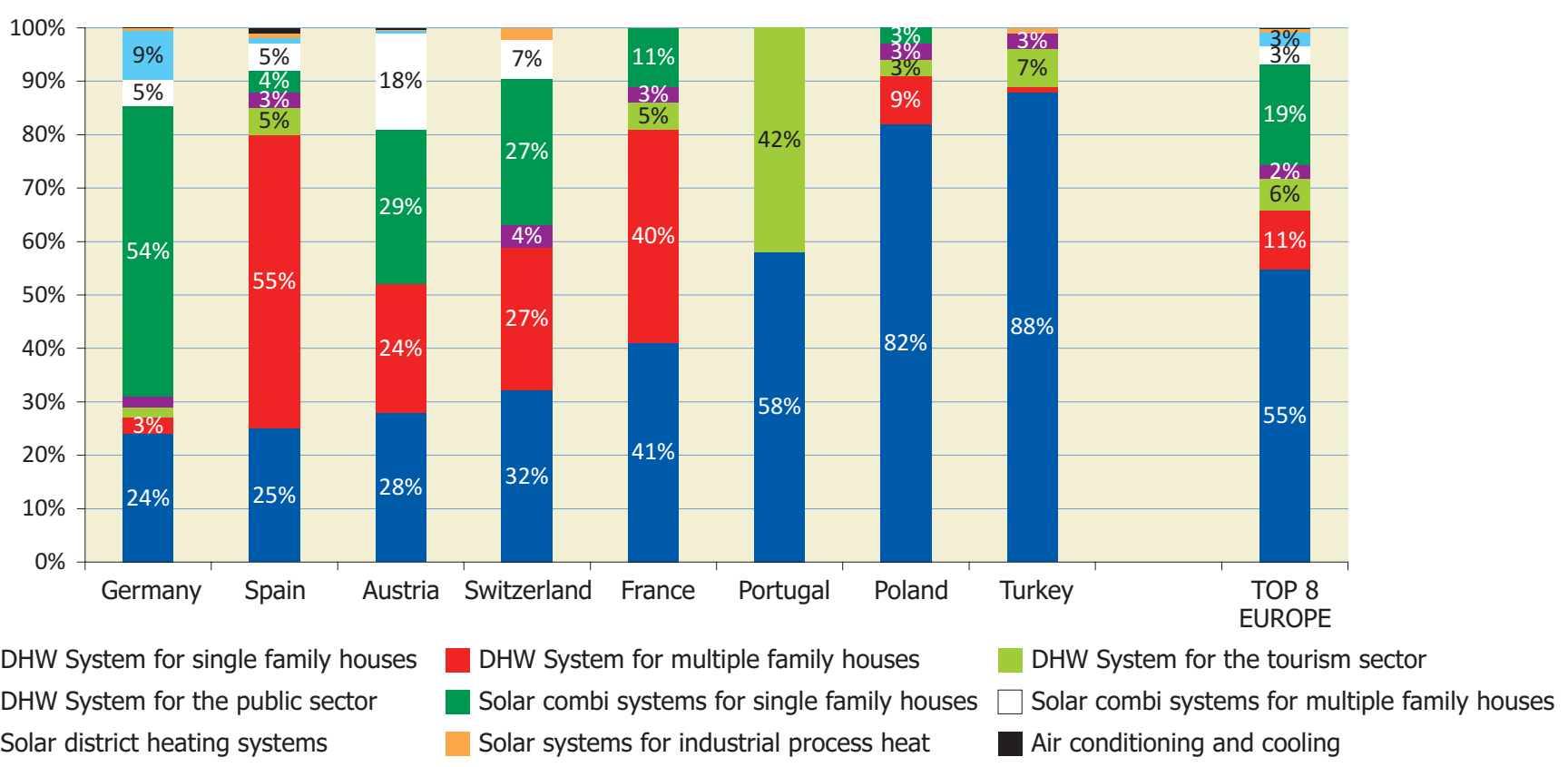

Figure 46: Distribution of different applications of the newly installed capacity of glazed water collectors for the 8 leading European countries in 2010 


\subsection{Worldwide large scale solar thermal applications}

Megawatt-scale solar supported district heating systems and solar heating and cooling applications in the commercial and industrial sector have gained increasing interest all over the world in recent years and several ambitious projects have been successfully implemented in the past.

In July 2011, the world's largest solar thermal system was commissioned in Riyadh, Saudi Arabia. The solar thermal plant, with a total capacity of $25 \mathrm{MW}_{\text {th }}\left(36.305 \mathrm{~m}^{2}\right)$, is connected to a district heating network for the supply of space heating and domestic hot water of a university campus. Another successful solar supported heating network was implemented in Alberta, Canada. The Drake Landing community uses a $1.6 \mathrm{MW}_{\text {th }}\left(2.293 \mathrm{~m}^{2}\right)$ centralized solar thermal plant connected to a seasonal storage to supply more than $90 \%$ of the energy needed for space heating 52 detached energy efficient homes.

In Singapore, a large-scale solar thermal heating and cooling installation with a total capacity of $2.73 \mathrm{MW}_{\text {th }}$ $\left(3,900 \mathrm{~m}^{2}\right)$ started operation in 2011 as well. The roof mounted solar thermal plant is connected to a $1.76 \mathrm{MW}_{\text {th }}$ absorption chiller and supplies hot water and cooling to around 2,500 students, who live and study at a newly created $76,000 \mathrm{~m}^{2}$ campus.

The largest solar process heat applications are installed in China and connected to dyeing and weaving mill factories. The first plant of $9.1 \mathrm{MW}_{\mathrm{th}}\left(13,000 \mathrm{~m}^{2}\right)$ was constructed in the province of Zhejiang at Shaoxing Dyeing and Weaving Mill in Hangzhou and two other projects of $10.5 \mathrm{MW}_{\text {th }}\left(15,000 \mathrm{~m}^{2}\right)$ have been commissioned in the neighboring province of Jiangsu.

\subsection{European large scale solar thermal applications}

In the Scandinavian countries of Denmark and Sweden, but also in Germany, Austria, Spain and Greece large scale solar thermal applications connected to local or district heating grids have been in use since the early 1980s. By the end of 2010, 149 large scale systems with a total installed capacity of $215 \mathrm{MW}_{\text {th }}\left(307,300 \mathrm{~m}^{2}\right)$ were in operation and more than 80 plants larger than $700 \mathrm{~kW}_{\text {th }}\left(\right.$ or $\left.1,000 \mathrm{~m}^{2}\right)$ were reported in Europe.

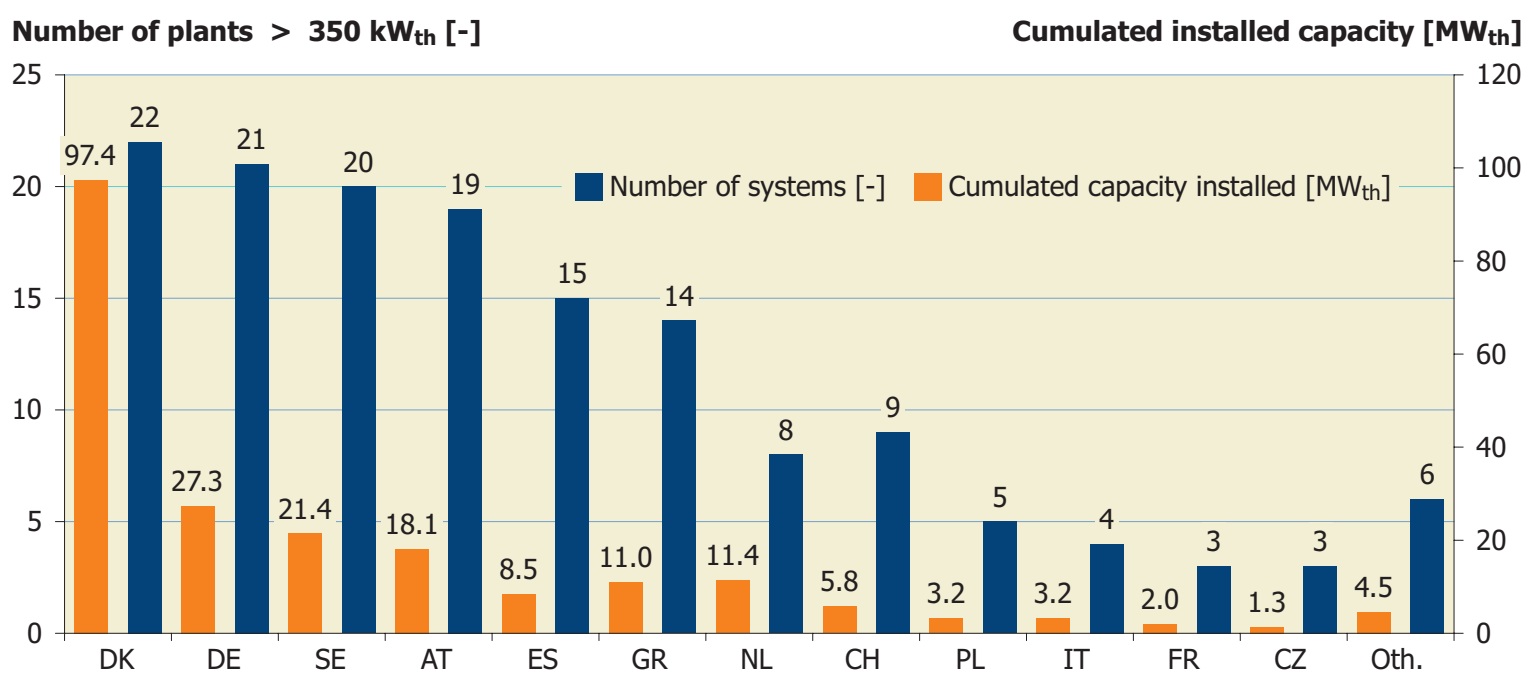

Figure 47: European large-scale solar heating plants by the end of 2010

(Source: Jan-Olof Dalenbäck - Chalmers University of Technology)

By end of 2011 the five largest European plants are installed in Denmark: Marstal (18,365 $\left.\mathrm{m}^{2}\right)$, Ringkøbing $\left(15,000 \mathrm{~m}^{2}\right)$, Sydfalster $\left(12,094 \mathrm{~m}^{2}\right)$, Sæby $\left(11,921 \mathrm{~m}^{2}\right)$ and $\operatorname{Gram}\left(10,073 \mathrm{~m}^{2}\right)$. The market for solar supported district heating networks in Denmark has been booming for several years and is driven by high taxes for natural gas 
and an energy supply system that is characterized by decentralization on the one hand and a high share of wind energy on the electricity production on the other hand. This together with the liberalized market mechanisms for electricity in Europe and very low solar thermal system prices for large-scale systems make solar thermal heat in Denmark even competitive against natural gas driven combined heat and power plants in many cases (source: http:/ /www.solar-district-heating.eu/).

\subsection{Market for solar air conditioning and cooling applications}

Solar cooling applications convert the energy from the sun into cold by means of driving a thermal cooling machine.

By the end of 2010 approximately 600 solar cooling systems were installed worldwide and the major markets were in Spain, Germany and Italy. The market still can be categorized as a niche market under development, but nevertheless the annual growth rates are high as can be seen in the following Figure 48.

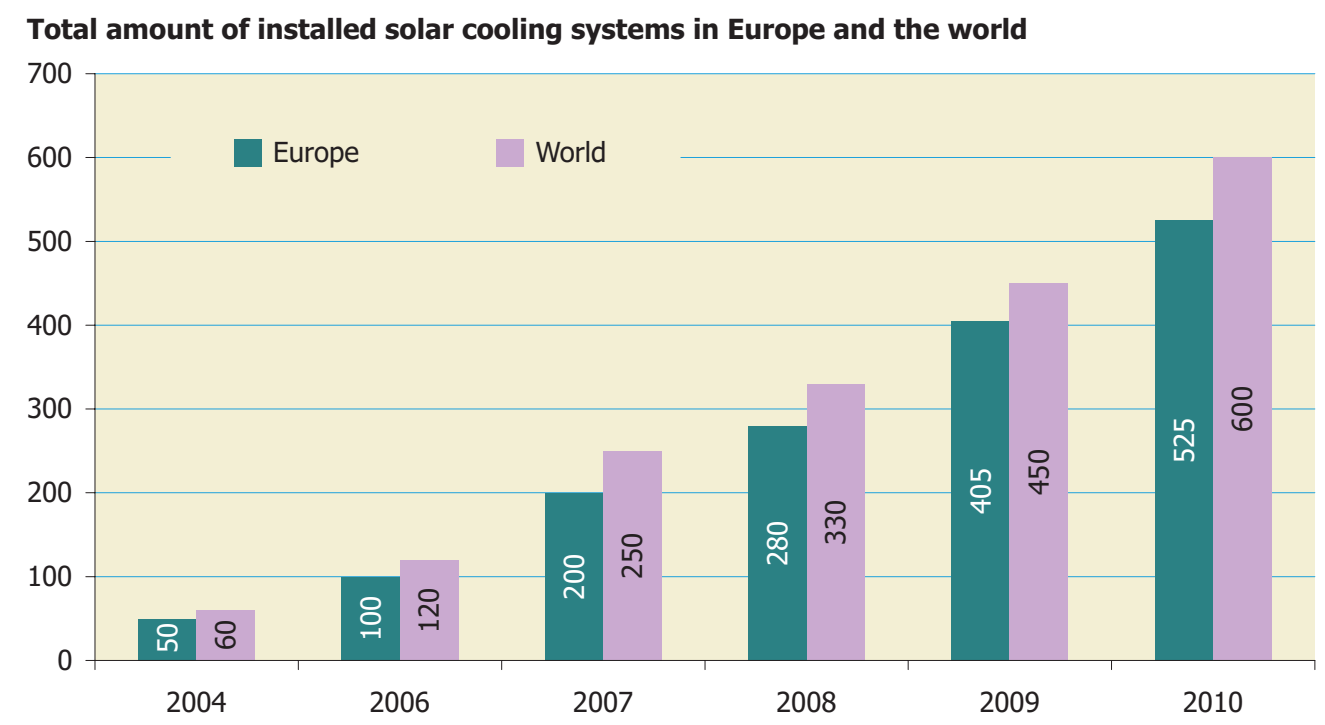

Figure 48: Market development of small to large-scale solar air conditioning and cooling systems worldwide as well as in Europe (Source: Solem Consulting / Climasol, Fraunhofer ISE, Rococo, Tecsol) 


\section{$7 \quad$ Appendix}

\subsection{Methodological approach for the energy calculation}

In order to obtain the energy yield of solar thermal systems, the oil equivalent saved and the $\mathrm{CO}_{2}$ emissions avoided, the following procedure was used:

- Only water collectors were used in the calculations (unglazed, flat-plate and evacuated tube collectors). Air collectors were not included.

- For each country, the cumulated water collector area was allocated to the following applications:

- Solar thermal systems for swimming pool heating with unglazed water collectors,

- Solar domestic hot water systems for single-family houses,

- Solar domestic hot water systems for multifamily houses including the tourism sector as well as the public sector (to simplify the analysis solar district heating systems, solar process heat and solar cooling applications were also allocated here)

- Solar combi systems ${ }^{7}$ for domestic hot water and space heating for single- and multifamily houses.

- Reference systems were defined for each country and for each type of application.

- The number of plants per country was determined from the share of collector area for each application and the collector area defined for the reference system.

Reference collectors and a reference climate were determined for each country apart from the reference plants. On the basis of these reference conditions, simulations were performed with the simulation program T-Sol [T-Sol, Version 4.5 Expert, Valentin Energiesoftware, www.valentin.de] to obtain the solar yields.

Finally the annual collector yield per square meter of collector area, depending on the application, the local climatic conditions and the plant dimensions (high or low solar fraction) were calculated for each country and each system.

The amount of energy saved considering the utilization rate of the auxiliary heating system ${ }^{8}$ is expressed in tons of oil equivalent (toe): 1 toe $=11,630 \mathrm{kWh}$.

The $\mathrm{CO}_{2}$ emissions avoided by the different solar thermal applications were ascertained from the energy savings (oil equivalent): 1 toe $=3.1 \mathrm{t}_{\mathrm{CO} 2}{ }^{9}$

To obtain an exact statement about the $\mathrm{CO}_{2}$ emissions avoided, the substituted energy medium would have to be ascertained for each country. Since this could only be done in a very detailed survey, which goes beyond the scope of this report, the energy savings and the $\mathrm{CO}_{2}$ emissions avoided therefore relate to fuel oil. It is obvious that not all solar thermal systems just replace systems running on oil. This represents a simplification since gas, coal, biomass or electricity can be used as the energy source for the auxiliary heating system instead of oil.

The following tables describe the key data of the reference systems in the different countries, the location of the reference climate used and the share of the total collector area in use for the respective application. Furthermore, a hydraulic scheme is shown for each reference system.

7 Solar combi-systems are solar heating installations that provide both space heating and domestic hot water.

8 For the swimming pool applications a utilization rate of 0.9 is assumed in the calculation and for all other applications an average utilization rate of 0.8 is used.

9 Only direct emissions for fuel oil are considered referring to GEMIS database, version 4.6 


\subsubsection{Solar thermal systems for swimming pool heating with unglazed collectors}

\begin{tabular}{|c|c|c|c|c|}
\hline Country & Reference climate & $\begin{array}{c}\text { Collector area } \\
\text { (gross area) for } \\
\text { single system [m²] }\end{array}$ & $\begin{array}{l}\text { Total collector } \\
\text { area unglazed } \\
2010\left[\mathrm{~m}^{2}\right]\end{array}$ & $\begin{array}{c}\text { Total number } \\
\text { of systems unglazed } \\
2010[-]\end{array}$ \\
\hline Australia & Sydney & 34 & 5.400 .000 & 158.824 \\
\hline Austria & Graz & 200 & 599.491 & 2.997 \\
\hline Belgium & Brussels & 200 & 46.875 & 234 \\
\hline Brazil & Brasília & 200 & 1.277 .128 & 6.386 \\
\hline Canada & Montreal & 200 & 656.485 & 3.282 \\
\hline Cyprus & Nicosia & 200 & 3.363 & 17 \\
\hline Czech Republic & Prague & 200 & 150.000 & 750 \\
\hline Denmark & Copenhagen & 200 & 20.515 & 103 \\
\hline 762 Finland & Helsinki & 200 & 11.779 & 59 \\
\hline France incl. DOM & Paris & 200 & 89.181 & 446 \\
\hline Germany & Wurzburg & 200 & 637.010 & 3.185 \\
\hline Hungary & Budapest & 200 & 8.088 & 40 \\
\hline Ireland & Dublin & 200 & 421 & 2 \\
\hline Israel & Jerusalem & 200 & 29.900 & 150 \\
\hline Italy & Bologna & 200 & 43.766 & 219 \\
\hline Jordan & Amman & 200 & 5.940 & 30 \\
\hline Mexico & Mexico City & 200 & 662.092 & 3.310 \\
\hline Netherlands & Amsterdam & 200 & 396.410 & 1.982 \\
\hline New Zealand & Wellington & 200 & 7.025 & 35 \\
\hline Norway & Oslo & 200 & 2.011 & 10 \\
\hline Portugal & Lisbon & 200 & 2.435 & 12 \\
\hline South Africa & Johannesburg & 200 & 803.678 & 4.018 \\
\hline Spain & Madrid & 200 & 122.000 & 610 \\
\hline Sweden & Gothenburg & 200 & 140.000 & 700 \\
\hline Switzerland & Zürich & 200 & 212.850 & 1.064 \\
\hline Taiwan & Taipei & 200 & 85 & 0 \\
\hline United States & LA, Indianapolis & 200 & 19.361 .098 & 96.805 \\
\hline Total & & & 30.689 .627 & 285.272 \\
\hline
\end{tabular}

* Countries not listed in this table means that there was no reliable database for unglazed collectors available

Table 8: Solar thermal swimming pool heating reference systems with unglazed water collectors and the total collector area in operation by the end of 2010

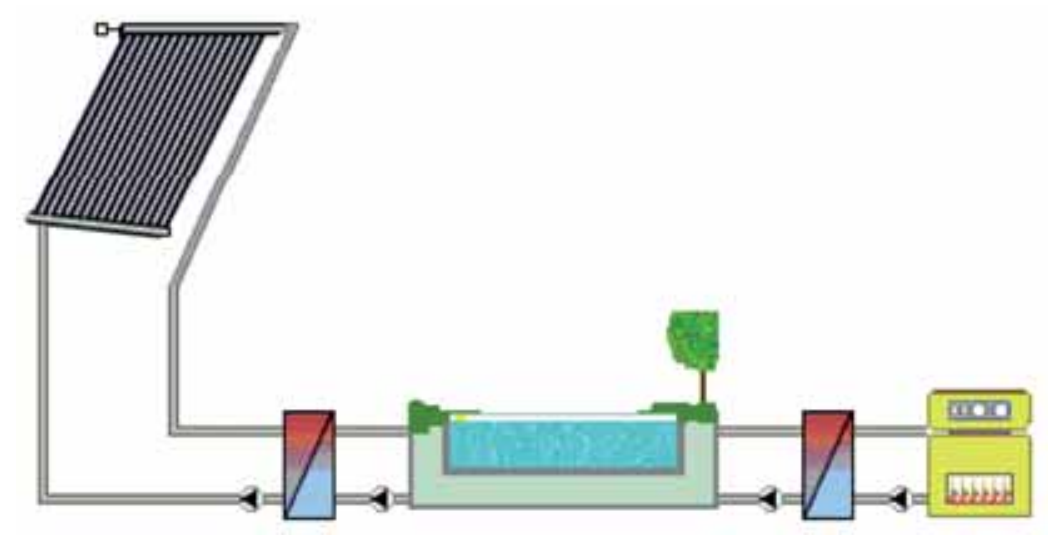

Figure 49: Hydraulic scheme of the swimming pool reference system 


\subsubsection{Solar domestic hot water systems for single-family houses}

The market share in the following table refers to the total capacity in operation of glazed water collectors (FPC + ETC) by the end of 2010 for each country. It must be pointed out that the market share of the new installed capacity in the year 2010 can differ significantly from the total market share.

\begin{tabular}{|c|c|c|c|c|c|c|}
\hline Country & $\begin{array}{l}\text { Reference } \\
\text { climate }\end{array}$ & $\begin{array}{l}\text { Collector area } \\
\text { (gross area) for } \\
\text { single sys. [m²] }\end{array}$ & $\begin{array}{c}\text { Total collector } \\
\text { area-SFH } \\
2010\left[\mathrm{~m}^{2}\right]\end{array}$ & $\begin{array}{c}\text { Share of } \\
\text { DHW-SFH } \\
\text { [\%] }\end{array}$ & $\begin{array}{c}\text { Total number } \\
\text { of systems SFH } \\
2010[-]\end{array}$ & $\begin{array}{l}\text { Type of } \\
\text { system [-] }\end{array}$ \\
\hline Albania & Tirana & 2,5 & 22.543 & $29 \%$ & 9.017 & TS \\
\hline Australia & Sydney & 6,0 & 2.857 .251 & $98 \%$ & 476.209 & PS \\
\hline Austria & Graz & 6,0 & 1.858 .739 & $47 \%$ & 309.790 & PS \\
\hline Barbados & Grantley Adams & 4,0 & 131.690 & $100 \%$ & 32.923 & TS \\
\hline Belgium & Brussels & 4,0 & 316.634 & $100 \%$ & 79.159 & PDS \\
\hline Brazil & Brasília & 4,0 & 4.157 .540 & $86 \%$ & 1.039 .385 & TS \\
\hline Bulgaria & Sofia & 4,0 & 33.306 & $71 \%$ & 8.327 & PS \\
\hline Canada & Montreal & 6,0 & 33.107 & $50 \%$ & 5.518 & PS \\
\hline Chile & Santiago de Chile & 4,0 & 12.953 & $46 \%$ & 3.238 & PS \\
\hline China & Shanghai & 4,0 & 151.200 .000 & $90 \%$ & 37.800 .000 & TS \\
\hline Cyprus & Nicosia & 4,0 & 786.811 & $87 \%$ & 196.703 & TS \\
\hline Czech Republic & Prague & 6,0 & 178.605 & $58 \%$ & 29.767 & PS \\
\hline Denmark & Copenhagen & 4,0 & 455.708 & $86 \%$ & 113.927 & PS \\
\hline Estonia & Tallinn & 4,0 & 2.841 & $100 \%$ & 710 & PS \\
\hline Finland & Helsinki & 4,0 & 32.738 & $95 \%$ & 8.184 & PS \\
\hline France incl. DOM & Paris & 4,0 & 1.645 .272 & $75 \%$ & 411.318 & PS \\
\hline Germany & Wurzburg & 6,0 & 5.887 .419 & $45 \%$ & 981.237 & PS \\
\hline Greece & Athens & 2,5 & 4.005 .260 & $98 \%$ & 1.602 .104 & TS \\
\hline Hungary & Budapest & 6,0 & 74.907 & $50 \%$ & 12.485 & PS \\
\hline India & Delhi & 4,0 & 3.176 .000 & $80 \%$ & 794.000 & TS \\
\hline Ireland & Dublin & 4,0 & 136.059 & $90 \%$ & 34.015 & PS \\
\hline Israel & Jerusalem & 4,0 & 827.579 & $20 \%$ & 206.895 & TS \\
\hline Italy & Bologna & 4,0 & 2.547 .578 & $100 \%$ & 636.895 & PS \\
\hline Japan & Tokyo & 4,0 & 5.175 .606 & $98 \%$ & 1.293 .901 & TS \\
\hline Jordan & Amman & 4,0 & 790.050 & $80 \%$ & 197.512 & TS \\
\hline Korea, South & Seoul & 4,0 & 845.812 & $54 \%$ & 211.453 & PS \\
\hline Latvia & Riga & 4,0 & 7.244 & $100 \%$ & 1.811 & PS \\
\hline Lebanon & Beirut & 4,0 & 348.312 & $100 \%$ & 87.078 & TS \\
\hline Lithuania & Vilnius & 4,0 & 4.518 & $100 \%$ & 1.130 & PS \\
\hline Luxembourg & Luxembourg & 4,0 & 30.800 & $100 \%$ & 7.700 & PS \\
\hline Macedonia & Skopje & 4,0 & 12.100 & $47 \%$ & 3.025 & PS \\
\hline Malta & Luqa & 4,0 & 43.469 & $100 \%$ & 10.867 & PS \\
\hline Mexico & Mexico City & 4,0 & 243.561 & $28 \%$ & 60.890 & PS \\
\hline Morocco & Rabat & 4,0 & 341.260 & $100 \%$ & 85.315 & TS \\
\hline Namibia & Windhoek & 4,0 & 9.903 & $45 \%$ & 2.476 & TS \\
\hline Netherlands & Amsterdam & 3,0 & 331.857 & $80 \%$ & 110.619 & PDS \\
\hline New Zealand & Wellington & 4,0 & 144.989 & $95 \%$ & 36.247 & PS \\
\hline Norway & Oslo & 6,0 & 15.151 & $98 \%$ & 2.525 & PS \\
\hline Poland & Warsaw & 6,0 & 459.060 & $70 \%$ & 76.510 & PS \\
\hline Portugal & Lisbon & 4,0 & 525.951 & $70 \%$ & 131.488 & PS \\
\hline Romania & Bucharest & 4,0 & 109.996 & $100 \%$ & 27.499 & PS \\
\hline Slovakia & Bratislava & 6,0 & 135.746 & $100 \%$ & 22.624 & PS \\
\hline Slovenia & Ljubljana & 6,0 & 135.869 & $83 \%$ & 22.645 & PS \\
\hline South Africa & Johannesburg & 4,0 & 359.682 & $100 \%$ & 89.920 & TS \\
\hline Spain & Madrid & 4,0 & 818.300 & $35 \%$ & 204.575 & PS \\
\hline Sweden & Gothenburg & 6,0 & 30.200 & $10 \%$ & 5.033 & PS \\
\hline Switzerland & Zürich & 6,0 & 532.824 & $67 \%$ & 88.804 & PS \\
\hline Taiwan & Taipei & 4,0 & 1.933 .245 & $95 \%$ & 483.311 & TS \\
\hline Thailand & Bangkok & 4,0 & 91.392 & $100 \%$ & 22.848 & TS \\
\hline Tunisia & Tunis & 4,0 & 475.009 & $97 \%$ & 118.752 & TS \\
\hline Turkey & Ankara & 4,0 & 12.253 .166 & $92 \%$ & 3.063 .292 & TS \\
\hline United Kingdom & London & 4,0 & 564.783 & $100 \%$ & 141.196 & PS \\
\hline United States & LA, Indianapolis & 6,0 & 2.446 .342 & $100 \%$ & 407.724 & PS \\
\hline Uruguay & Montevideo & 4,0 & 12.096 & $100 \%$ & 3.024 & PS \\
\hline Zimbabwe & Harare & 4,0 & 18.196 & $100 \%$ & 4.549 & PS \\
\hline Total & & & 209.627 .029 & $85 \%$ & 51.818 .147 & \\
\hline
\end{tabular}

DHW-SFH: domestic hot water systems

TS: thermosiphon system

PS: pumped system for single-family houses

PDS: pumped drain back system

Auxiliary heating device: oil boiler

Table 9: Domestic hot water reference systems for single family houses and the total collector area in operation by the end of 2010 
Figure $\mathbf{5 0}$ shows the hydraulic scheme used for the energy calculation for all pumped solar thermal systems and Figure 51 refers to the thermosiphon systems.

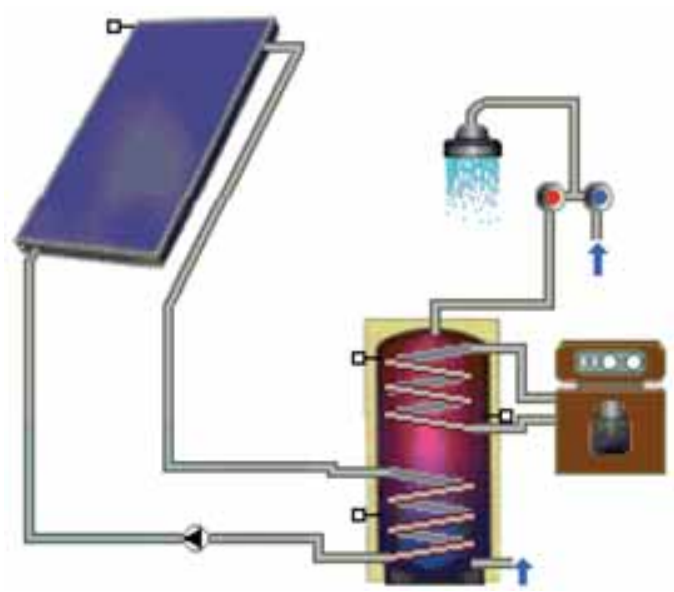

Figure 50: Hydraulic scheme of the DHW pumped reference system

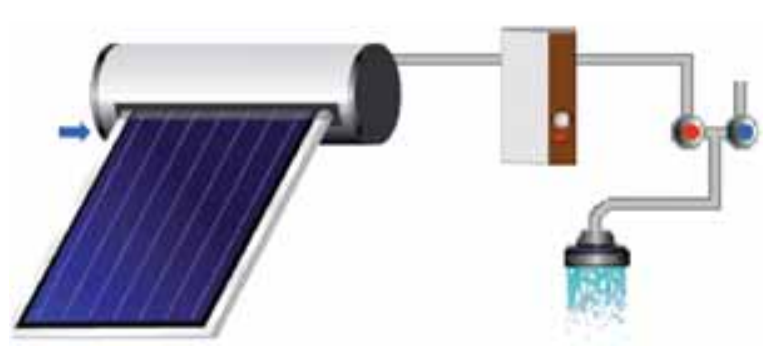

Figure 51: Hydraulic scheme of the DHW thermosiphon reference system

For the Chinese thermosiphon systems, the above reference system was used but instead of a flat plate collector as shown in Figure $\mathbf{5 1}$ a representative Chinese vacuum tube collector was used for the simulation.

\subsubsection{Solar domestic hot water systems for multifamily houses, hotels and district heating}

The market share shown in Table 10 refers to the total capacity in operation of flat plate and evacuated tube collectors by the end of 2010 for each country. It must be pointed out that the market share of the newly installed capacity in the year 2010 can differ greatly from the total market share. 


\begin{tabular}{|c|c|c|c|c|c|c|}
\hline Country & $\begin{array}{l}\text { Reference } \\
\text { climate }\end{array}$ & $\begin{array}{l}\text { Collector area } \\
\text { (gross area) for } \\
\text { single sys. [m²] }\end{array}$ & $\begin{array}{c}\text { Total collector } \\
\text { area-MFH } \\
2010\left[\mathrm{~m}^{2}\right]\end{array}$ & $\begin{array}{c}\text { Share of } \\
\text { DHW-MFH } \\
{[\%]}\end{array}$ & $\begin{array}{l}\text { Total number } \\
\text { of systems } \\
\text { SFH } 2010 \text { [- }\end{array}$ & $\begin{array}{l}\text { Type of } \\
\text { System } \\
{[-]}\end{array}$ \\
\hline Albania & Tirana & 2,5 & 55.190 & $71,0 \%$ & 22.076 & PS \\
\hline Australia & Sydney & 6,0 & 58.311 & $2,0 \%$ & 9.719 & PS \\
\hline Austria & Graz & 6,0 & 346.678 & $8,8 \%$ & 57.780 & PS \\
\hline Brazil & Brasília & 4,0 & 676.809 & $14,0 \%$ & 169.202 & PS \\
\hline Bulgaria & Sofia & 4,0 & 13.430 & $28,7 \%$ & 3.357 & PS \\
\hline Canada & Montreal & 6,0 & 33.107 & $50,0 \%$ & 5.518 & PS \\
\hline Chile & Santiago de Chile & 4,0 & 15.206 & $54,0 \%$ & 3.801 & PS \\
\hline China & Shanghai & 4,0 & 14.280 .000 & $8,5 \%$ & 3.570 .000 & PS \\
\hline Cyprus & Nicosia & 4,0 & 104.123 & $11,5 \%$ & 26.031 & PS \\
\hline Czech Republic & Prague & 6,0 & 9.238 & $3,0 \%$ & 1.540 & PS \\
\hline Denmark & Copenhagen & 4,0 & 68.886 & $13,0 \%$ & 17.222 & PS \\
\hline Finland & Helsinki & 4,0 & 1.723 & $5,0 \%$ & 431 & PS \\
\hline France incl. DOM & Paris & 4,0 & 219.370 & $10,0 \%$ & 54.842 & PS \\
\hline Germany & Wurzburg & 6,0 & 1.596 .145 & $12,2 \%$ & 266.024 & PS \\
\hline Greece & Athens & 2,5 & 81.740 & $2,0 \%$ & 32.696 & PS \\
\hline Hungary & Budapest & 6,0 & 47.940 & $32,0 \%$ & 7.990 & PS \\
\hline India & Delhi & 4,0 & 794.000 & $20,0 \%$ & 198.500 & PS \\
\hline Ireland & Dublin & 4,0 & 4.535 & $3,0 \%$ & 1.134 & PS \\
\hline Israel & Jerusalem & 4,0 & 3.310 .316 & $80,0 \%$ & 827.579 & PS \\
\hline Japan & Tokyo & 4,0 & 6.578 & $0,1 \%$ & 1.645 & PS \\
\hline Jordan & Amman & 4,0 & 197.512 & $20,0 \%$ & 49.378 & PS \\
\hline Korea, South & Seoul & 4,0 & 720.507 & $46,0 \%$ & 180.127 & PS \\
\hline Macedonia & Skopje & 4,0 & 13.644 & $53,0 \%$ & 3.411 & PS \\
\hline Mexico & Mexico City & 4,0 & 626.301 & $72,0 \%$ & 156.575 & PS \\
\hline Namibia & Windhoek & 4,0 & 12.103 & $55,0 \%$ & 3.026 & PS \\
\hline Netherlands & Amsterdam & 3,0 & 62.223 & $15,0 \%$ & 20.741 & PS \\
\hline New Zealand & Wellington & 4,0 & 7.631 & $5,0 \%$ & 1.908 & PS \\
\hline Norway & Oslo & 6,0 & 155 & $1,0 \%$ & 26 & PS \\
\hline Poland & Warsaw & 6,0 & 163.950 & $25,0 \%$ & 27.325 & PS \\
\hline Portugal & Lisbon & 4,0 & 225.407 & $30,0 \%$ & 56.352 & PS \\
\hline Slovenia & Ljubljana & 6,0 & 3.274 & $2,0 \%$ & 546 & PS \\
\hline Spain & Madrid & 4,0 & 1.309 .280 & $56,0 \%$ & 327.320 & PS \\
\hline Sweden & Gothenburg & 6,0 & 45.300 & $15,0 \%$ & 7.550 & PS \\
\hline Switzerland & Zürich & 6,0 & 63.621 & $8,0 \%$ & 10.603 & PS \\
\hline Taiwan & Taipei & 4,0 & 112.517 & $5,5 \%$ & 28.129 & PS \\
\hline Tunisia & Tunis & 4,0 & 14.691 & $3,0 \%$ & 3.673 & PS \\
\hline Turkey & Ankara & 4,0 & 1.065 .493 & $8,0 \%$ & 266.373 & PS \\
\hline Total & & & 26.366 .936 & $11 \%$ & 6.420 .149 & \\
\hline
\end{tabular}

DHW-MFH: domestic hot water systems for multifamily houses

PS: $\quad$ pumped system

Table 10: Domestic hot water reference systems for multifamily houses, hotels and district heating and the total collector area in operation in 2010

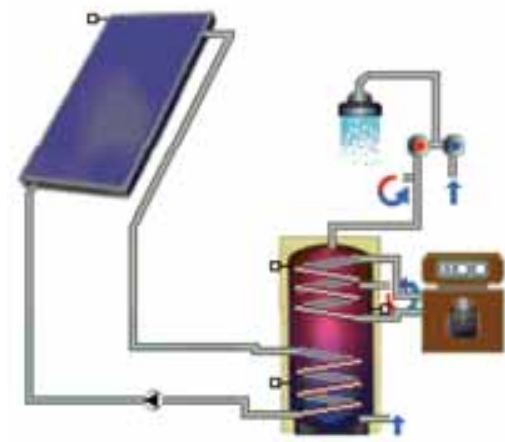

Figure 52: Hydraulic scheme of the DHW system for multifamily houses 


\subsubsection{Solar combi-systems for domestic hot water and space heating for single- family houses}

The market share of combi-systems in the following table refers to the total capacity in operation of flat-plate and evacuated tube collectors at the end of 2009 for each country. It must be pointed out that the market share of the new installed capacity in the year 2009 can differ significantly from the total market share. The reference system is designed for a single-family house with a $140 \mathrm{~m}^{2}$ heated floor area.

\begin{tabular}{|c|c|c|c|c|c|c|}
\hline Country & $\begin{array}{l}\text { Reference } \\
\text { climate }\end{array}$ & $\begin{array}{l}\text { Collector area } \\
\text { (gross area) for } \\
\text { single sys. [m²] }\end{array}$ & \begin{tabular}{|c|} 
Total collector \\
area-combi sys. \\
$2010\left[\mathrm{~m}^{2}\right]$
\end{tabular} & $\begin{array}{c}\text { Share of combi } \\
\text { systems } \\
{[\%]}\end{array}$ & $\begin{array}{c}\text { Total number } \\
\text { of systems SFH } \\
2010[-]\end{array}$ & $\begin{array}{c}\text { Type of } \\
\text { system } \\
{[-]}\end{array}$ \\
\hline Austria & Graz & 16,0 & 1.753 .370 & $47,0 \%$ & 109.586 & PS \\
\hline China & Shanghai & 12,0 & 2.520 .000 & $90,0 \%$ & 210.000 & PS \\
\hline Cyprus & Nicosia & 12,0 & 14.487 & $86,9 \%$ & 1.207 & PS \\
\hline Czech Republic & Prague & 12,0 & 120.096 & $58,0 \%$ & 10.008 & PS \\
\hline Denmark & Copenhagen & 12,0 & 5.299 & $86,0 \%$ & 442 & PS \\
\hline France incl. DOM & Paris & 15,0 & 329.054 & $75,0 \%$ & 21.937 & PS \\
\hline Germany & Wurzburg & 12,0 & 5.599 .590 & $45,0 \%$ & 466.632 & PS \\
\hline Hungary & Budapest & 12,0 & 26.967 & $50,0 \%$ & 2.247 & PS \\
\hline Ireland & Dublin & 12,0 & 10.582 & $90,0 \%$ & 882 & PS \\
\hline Japan & Tokyo & 12,0 & 118.799 & $97,6 \%$ & 9.900 & PS \\
\hline Netherlands & Amsterdam & 6,0 & 20.741 & $80,0 \%$ & 3.457 & PS \\
\hline Norway & Oslo & 12,0 & 155 & $98,0 \%$ & 13 & PS \\
\hline Poland & Warsaw & 12,0 & 32.790 & $70,0 \%$ & 2.733 & PS \\
\hline Slovenia & Ljubljana & 12,0 & 24.555 & $83,0 \%$ & 2.046 & PS \\
\hline Spain & Madrid & 12,0 & 210.420 & $35,0 \%$ & 17.535 & PS \\
\hline Sweden & Gothenburg & 12,0 & 226.500 & $10,0 \%$ & 18.875 & PS \\
\hline Switzerland & Zürich & 12,0 & 198.815 & $67,0 \%$ & 16.568 & PS \\
\hline Total & & & 11.212 .219 & $4,5 \%$ & 894.067 & \\
\hline
\end{tabular}

combi-system: system for the supply of domestic hot water and space heating

PS: $\quad$ pumped system

Table 11: Solar combi reference systems for single and multifamily houses and the total collector area in operation in 2010

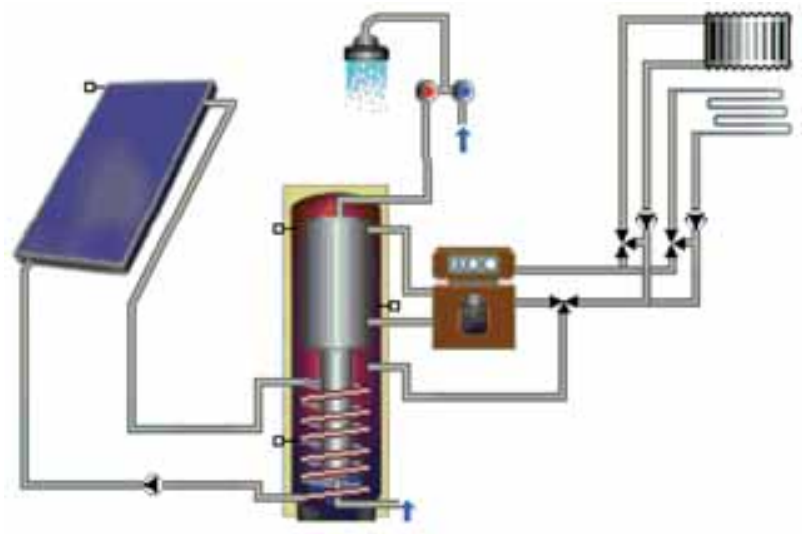

Figure 53: Hydraulic scheme of the solar combi reference system 


\subsection{Reference collectors}

\subsubsection{Data of the reference} unglazed water collector for swimming pool heating

$$
\begin{aligned}
& \eta=0.85 \\
& a_{1}=20\left[\mathrm{~W} / \mathrm{m}^{2} \mathrm{~K}\right] \\
& \mathrm{a}_{2}=0.1\left[\mathrm{~W} / \mathrm{m}^{2} \mathrm{~K}^{2}\right]
\end{aligned}
$$

7.2.2 Data of the reference collector for all other applications except for China

$$
\begin{aligned}
& \eta=0.8 \\
& a_{1}=3.69\left[\mathrm{~W} / \mathrm{m}^{2} \mathrm{~K}\right] \\
& \mathrm{a}_{2}=0.007\left[\mathrm{~W} / \mathrm{m}^{2} \mathrm{~K}^{2}\right]
\end{aligned}
$$

\begin{tabular}{|c|c|c|c|c|}
\hline \multirow{2}{*}{ Country } & \multirow{2}{*}{ Reference climate } & Horizontal irradiation & Inclined irradiation & Avg. Outside air temp. \\
\hline & & {$\left[\mathrm{kWh} / \mathrm{m}^{2} \cdot \mathrm{a}\right]$} & {$\left[\mathrm{kWh} / \mathrm{m}^{2} \cdot \mathrm{a}\right]$} & {$\left[{ }^{\circ} \mathrm{C}\right]$} \\
\hline Albania & Tirana & 1.604 & 1.835 & 13,5 \\
\hline Australia & Sydney & 1.674 & 1.841 & 18,1 \\
\hline Austria & Graz & 1.126 & 1.280 & 9,2 \\
\hline Barbados & Grantley Adams & 2.016 & 2.048 & 27,4 \\
\hline Belqium & Brussels & 971 & 1.095 & 10,0 \\
\hline Brazil & Brasília & 1.793 & 1.838 & 22,0 \\
\hline Bulqaria & Sofia & 1.188 & 1.304 & 10,1 \\
\hline Canada & Montreal & 1.351 & 1.568 & 6,9 \\
\hline Chile & Santiago de Chile & 1.753 & 1.850 & 14,5 \\
\hline China & Shanghai & 1.282 & 1.343 & 17,1 \\
\hline Cyprus & Nicosia & 1.886 & 2.098 & 19,9 \\
\hline Czech Republic & Praque & 998 & 1.111 & 7,9 \\
\hline Denmark & Copenhagen & 989 & 1.164 & 8,1 \\
\hline Estonia & Tallinn & 960 & 1.126 & 5,3 \\
\hline Finland & Helsinki & 948 & 1.134 & 4,6 \\
\hline France incl. DOM & Paris & 1.112 & 1.246 & 11,0 \\
\hline Germany & Wurzburg & 1.091 & 1.225 & 9,5 \\
\hline Greece & Athens & 1.585 & 1.744 & 18,5 \\
\hline Hungary & Budapest & 1.199 & 1.346 & 11,0 \\
\hline India & Delhi & 1.961 & 2.275 & 24,7 \\
\hline Ireland & Dublin & 949 & 1.091 & 9,5 \\
\hline Israel & Jerusalem & 2.198 & 2.400 & 17,3 \\
\hline Italy & Bologna & 1.419 & 1.592 & 14,3 \\
\hline Japan & Tokyo & 1.175 & 1.287 & 16,7 \\
\hline Jordan & Amman & 2.145 & 2.341 & 17,9 \\
\hline Korea, South & Seoul & 1.161 & 1.280 & 12,7 \\
\hline Latvia & Riga & 991 & 1.187 & 6,3 \\
\hline Lebanon & Beirut & 1.935 & 2.132 & 19,9 \\
\hline Lithuania & Vilnius & 1.001 & 1.161 & 6,2 \\
\hline Luxembourg & Luxembourg & 1.037 & 1.158 & 8,4 \\
\hline Macedonia & Skopje & 1.381 & 1.521 & 12,5 \\
\hline Malta & Luqa & 1.902 & 2.115 & 18,7 \\
\hline Mexico & Mexico City & 1.706 & 1.759 & 16,6 \\
\hline Morocco & Rabat & 2.011 & 2.281 & 17,8 \\
\hline Namibia & Windhoek & 2.363 & 2.499 & 21,0 \\
\hline Netherlands & Amsterdam & 999 & 1.131 & 10,0 \\
\hline New Zealand & Wellington & 1.401 & 1.542 & 13,6 \\
\hline Norway & Oslo & 971 & 1.208 & 5,8 \\
\hline Poland & Warsaw & 1.024 & 1.156 & 8,1 \\
\hline Portugal & Lisbon & 1.686 & 1.875 & 17,4 \\
\hline Romania & Bucharest & 1.324 & 1.473 & 10,6 \\
\hline Slovakia & Bratislava & 1.214 & 1.374 & 10,3 \\
\hline Slovenia & Ljubljana & 1.115 & 1.231 & 9,8 \\
\hline South Africa & Johannesburg & 2.075 & 2.232 & 15,6 \\
\hline Spain & Madrid & 1.644 & 1.844 & 15,5 \\
\hline Sweden & Gothenburg & 934 & 1.105 & 7,2 \\
\hline Switzerland & Zürich & 1.094 & 1.218 & 9,6 \\
\hline Taiwan & Taipei & 1.372 & 1.398 & 20,8 \\
\hline Thailand & Bangkok & 1.765 & 1.898 & 29,1 \\
\hline Tunisia & Tunis & 1.808 & 2.038 & 19,3 \\
\hline Turkey & Ankara & 1.701 & 1.886 & 12,0 \\
\hline United Kinqdom & London & 943 & 1.062 & 12,0 \\
\hline United States & LA, Indianapolis & 1.646 & 1.816 & 14,3 \\
\hline Uruquay & Montevideo & 1.534 & 1.647 & 15,9 \\
\hline Zimbabwe & Harare & 2.017 & 2.087 & 18,9 \\
\hline
\end{tabular}

\subsubsection{Data of the Chinese reference vacuum tube collector}

$$
\begin{aligned}
& \eta=0.74 \\
& a_{1}=2.5\left[\mathrm{~W} / \mathrm{m}^{2} \mathrm{~K}\right] \\
& \mathrm{a}_{2}=0.013\left[\mathrm{~W} / \mathrm{m}^{2} \mathrm{~K}^{2}\right]
\end{aligned}
$$

\subsection{Reference climates}

Table 12: Reference climates for the 55 countries surveyed 


\subsection{Population data}

\begin{tabular}{|l|r|}
\hline Country & $\mathbf{2 0 1 0}$ \\
\hline Albania & 2.986 .952 \\
\hline Australia & 21.515 .754 \\
\hline Austria & 8.214 .160 \\
\hline Barbados & 285.653 \\
\hline Belgium & 10.423 .493 \\
\hline Brazil & 201.103 .330 \\
\hline Bulgaria & 7.148 .785 \\
\hline Canada & 33.759 .742 \\
\hline Chile & 16.746 .491 \\
\hline China & 1.330 .141 .295 \\
\hline Cyprus & 1.102 .677 \\
\hline Czech Republic & 10.201 .707 \\
\hline Denmark & 5.515 .575 \\
\hline Estonia & 1.291 .170 \\
\hline Finland & 5.255 .068 \\
\hline France & 64.768 .389 \\
\hline Germany & 81.644 .454 \\
\hline Greece & 10.749 .943 \\
\hline Hungary & 9.992 .339 \\
\hline India & 1.173 .108 .018 \\
\hline
\end{tabular}

Data source: International Data Base of the U.S. Census Bureau http://www.census.gov/ipc/www/idb/country.php

Table 13: Inhabitants by the end of 2010 of the 55 surveyed countries in alphabetical order

\begin{tabular}{|l|r|r|}
\hline Region & $\Sigma$ Inhabitants & Share \\
\hline Sub-Saharan Africa & 62.889 .436 & $1,5 \%$ \\
\hline Asia excluding China & 1.438 .684 .445 & $34,3 \%$ \\
\hline Australia / New Zealand & 25.768 .031 & $0,6 \%$ \\
\hline Central / South America & 333.905 .405 & $8,0 \%$ \\
\hline China & 1.330 .141 .295 & $31,7 \%$ \\
\hline Europe & 596.644 .621 & $14,2 \%$ \\
\hline MENA Region & 60.038 .786 & $1,4 \%$ \\
\hline United States / Canada & 342.041 .795 & $8,2 \%$ \\
\hline TOTAL & 4.190 .113 .814 & $100,0 \%$ \\
\hline
\end{tabular}

Data source: International Data Base of the U.S. Census Bureau http://www.census.gov/ipc/www/idb/country.php

Asia excluding China: India, Japan, Korea South, Taiwan, Thailand

Central / South America: Barbados, Brazil, Chile, Mexico, Uruguay

Europe: Albania, EU 27, Macedonia, Norway, Switzerland, Turkey

MENA Region: Israel, Jordan, Lebanon, Morocco, Tunisia

Sub-Saharan Africa: Namibia, South Africa, Zimbabwe

Table 14: Inhabitants per economic region by the end of 2010

\subsection{Market data of the previous years}

The data presented in Chapters 3 through 5 were originally collected in square meters. Through an agreement of international experts the collector areas of these solar thermal applications have been converted and are shown in installed capacity as well.

Making the installed capacity of solar thermal collectors comparable with that of other energy sources, solar thermal experts from seven countries agreed upon a methodology to convert installed collector area into solar thermal capacity.

The methodology was developed during a meeting with IEA SHC Programme and major solar thermal trade associations in Gleisdorf, Austria in September 2004. The represented associations from Austria, Canada, Germany, the Netherlands, Sweden and the United States as well as the European Solar Thermal Industry Federation (ESTIF) and the IEA SHC Programme agreed to use a factor of $0.7 \mathrm{~kW}$ th $/ \mathrm{m}^{2}$ to derive the nominal capacity from the area of installed collectors.

In order to ensure consistency of the calculations within this report the following tables provide data from the previous years. If necessary the numbers have been revised in 2012 compared to the data originally published in earlier editions of this report due to changes in methodology or the origin of the data for each country.

In the following Table 15, Table 16 and Table 17 these countries are highlighted accordingly and in chapter 7.6 (references) the new data source is cited. 


\begin{tabular}{|c|c|c|c|c|c|c|}
\hline \multirow{2}{*}{ Country } & \multicolumn{3}{|c|}{ Water Collectors } & \multicolumn{2}{|c|}{ Air Collectors } & \multirow{2}{*}{ TOTAL $\left[\mathrm{m}^{2}\right]$} \\
\hline & unglazed & FPC & ETC & unglazed & glazed & \\
\hline Albania & & 9.740 & 104 & & & 9.844 \\
\hline Australia & 600.000 & 277.000 & 14.000 & & & 891.000 \\
\hline Austria & 15.220 & 343.617 & 4.086 & & & 362.923 \\
\hline Barbados & & 7.051 & 0 & & & 7.051 \\
\hline Belgium & & 82.000 & 9.000 & & & 91.000 \\
\hline Brazil & 278.910 & 392.246 & & & & 671.156 \\
\hline Bulgaria & & 4.000 & & & & 4.000 \\
\hline Canada & 89.577 & 13.173 & 1.083 & 34.135 & 1.191 & 139.159 \\
\hline Chile & & 7.094 & & & & 7.094 \\
\hline China & & 1.240 .000 & 29.760 .000 & & & 31.000 .000 \\
\hline Cyprus & & 40.290 & 1.000 & & & 41.290 \\
\hline Czech Republic & & 26.500 & 8.500 & & & 35.000 \\
\hline Denmark & & 31.000 & 2.000 & & & 33.000 \\
\hline Estonia & & 500 & & & & 500 \\
\hline Finland & 270 & 3.905 & 650 & & & 4.825 \\
\hline France incl. DOM* & & 372.000 & 16.000 & & & 388.000 \\
\hline IphaGermany & & 1.900 .000 & 200.000 & & 6.900 & 2.106 .900 \\
\hline Greece & & 293.500 & 4.500 & & & 298.000 \\
\hline Hungary & & 8.500 & 2.500 & & & 11.000 \\
\hline India & & 463.487 & 23.174 & & & 486.662 \\
\hline Ireland & & 31.727 & 11.883 & & & 43.610 \\
\hline Israel & 2.500 & 278.000 & & & & 280.500 \\
\hline Italy & & 428.571 & 71.429 & & & 500.000 \\
\hline Japan & & 205.622 & 1.946 & & 13.386 & 220.954 \\
\hline Jordan & & 20.041 & 30.062 & & & 50.103 \\
\hline Korea, South & & 51.552 & & & & 51.552 \\
\hline Latvia & & 1.800 & & & & 1.800 \\
\hline Lebanon & & 39.108 & & & & 39.108 \\
\hline Lithuania & & 840 & & & & 840 \\
\hline Luxembourg & & 2.800 & 800 & & & 3.600 \\
\hline Macedonia & & 3.866 & 554 & & & 4.420 \\
\hline Malta & & 6.000 & & & & 6.000 \\
\hline Mexico & 49.690 & 115.943 & & & & 165.633 \\
\hline Morocco & & 42.000 & & & & 42.000 \\
\hline Namibia & & 3.952 & 203 & & & 4.154 \\
\hline oNetherlands & 28.216 & 23.414 & & & & 51.630 \\
\hline New Zealand & 600 & 20.379 & & & & 20.979 \\
\hline Norway & 180 & 1.030 & 210 & & & 1.420 \\
\hline Poland & & 89.820 & 39.812 & & & 129.632 \\
\hline Portugal & 802 & 78.858 & 7.160 & & & 86.820 \\
\hline Romania & & 8.000 & & & & 8.000 \\
\hline Slovakia & & 12.000 & 1.500 & & & 13.500 \\
\hline Slovenia & & 14.000 & 2.500 & & & 16.500 \\
\hline South Africa* & 73.000 & 30.921 & 2.079 & & & 106.000 \\
\hline Spain & 32.000 & 409.000 & 25.000 & & & 466.000 \\
\hline Sweden & 28.648 & 14.530 & 12.283 & & & 55.461 \\
\hline Switzerland & 9.374 & 104.040 & 8.793 & 7.000 & & 129.207 \\
\hline Taiwan & 330 & 105.683 & 11.751 & & & 117.764 \\
\hline Thailand & & 9.939 & & & & 9.939 \\
\hline Tunisia & & 75.000 & 5.000 & & & 80.000 \\
\hline Turkey* & & 1.590 .300 & & & & 1.590 .300 \\
\hline United Kingdom & & 47.250 & 33.750 & & & 81.000 \\
\hline United States & 1.125 .771 & 175.272 & 28.194 & 0 & 2.249 & 1.331 .486 \\
\hline Uruguay & & 4.213 & & & & 4.213 \\
\hline Zimbabwe & & 336 & 24 & & & 360 \\
\hline TOTAL & 2.335 .088 & 9.561 .410 & 30.341 .530 & 41.135 & 23.727 & 42.302 .890 \\
\hline
\end{tabular}

*revised due to new / adapted database in 2012

Table 15: Newly installed collector area in 2008 [m²/a] 


\begin{tabular}{|c|c|c|c|c|c|c|}
\hline \multirow{2}{*}{ Country } & \multicolumn{3}{|c|}{ Water Collectors } & \multicolumn{2}{|c|}{ Air Collectors } & \multirow{2}{*}{ TOTAL $\left[\mathrm{m}^{2}\right]$} \\
\hline & unglazed & glazed & evacuated tube & unglazed & glazed & \\
\hline Albania & & 10.035 & 116 & & & 10.151 \\
\hline Australia & 620.000 & 483.019 & 36.356 & & & 1.139 .375 \\
\hline Austria & 8.342 & 348.408 & 7.759 & 378 & & 364.886 \\
\hline Barbados & & 7.051 & & & & 7.051 \\
\hline Belgium & & 45.500 & 5.200 & & & 50.700 \\
\hline Brazil & 407.051 & 391.089 & & & & 798.140 \\
\hline Bulgaria & & 8.000 & & & & 8.000 \\
\hline Canada & 73.026 & 9.186 & 1.083 & 45.331 & 792 & 129.418 \\
\hline Chile* & & 7.516 & & & & 7.516 \\
\hline China & & 2.000 .000 & 40.000 .000 & & & 42.000 .000 \\
\hline Cyprus & & 53.000 & 2.000 & & & 55.000 \\
\hline Czech Republic & & 30.000 & 10.000 & & & 40.000 \\
\hline Denmark & & 52.000 & 2.500 & & & 54.500 \\
\hline Estonia & & 60 & 390 & & & 450 \\
\hline Finland & & 2.800 & 1.200 & & & 4.000 \\
\hline France incl. DOM* & & 324.000 & 11.000 & & & 335.000 \\
\hline Germany & & 1.430 .000 & 185.000 & & & 1.615 .000 \\
\hline Greece & & 204.500 & 1.500 & & & 206.000 \\
\hline Hungary & 3.000 & 14.000 & 8.000 & 500 & 200 & 25.700 \\
\hline India & & 376.505 & 173.495 & & & 550.000 \\
\hline Ireland & & 26.383 & 16.131 & & & 42.514 \\
\hline Israel* & 2.950 & 291.900 & & & & 294.850 \\
\hline Italy* & & 415.625 & 59.375 & & & 475.000 \\
\hline Japan & & 139.821 & 1.682 & & 12.110 & 153.613 \\
\hline Jordan & & 30.435 & 9.091 & & & 39.526 \\
\hline Korea, South* & & 96.951 & & & & 96.951 \\
\hline Latvia & & 40 & 140 & & & 180 \\
\hline Lebanon & & 18.967 & 28.451 & & & 47.418 \\
\hline Lithuania & & 50 & 150 & & & 200 \\
\hline Luxembourg & & 3.650 & 1.050 & & & 4.700 \\
\hline Macedonia & & 3.002 & & & 4 & 3.006 \\
\hline Malta & & 4.386 & 4.122 & & & 8.508 \\
\hline Mexico & 75.501 & 82.002 & 70.430 & & 5.403 & 233.336 \\
\hline Morocco & & 40.968 & & & & 40.968 \\
\hline Namibia & & 3.979 & 244 & & & 4.224 \\
\hline Netherlands & 28.814 & 45.260 & & & & 74.074 \\
\hline New Zealand & 481 & 24.614 & & & & 25.095 \\
\hline Norway & 270 & 1.680 & 210 & & & 2.160 \\
\hline Poland & & 106.494 & 37.814 & & & 144.308 \\
\hline Portugal & 1.500 & 130.000 & 13.500 & & & 145.000 \\
\hline Romania & & 11.000 & 9.000 & & & 20.000 \\
\hline Slovakia & & 11.600 & 1.900 & & & 13.500 \\
\hline Slovenia & & 17.000 & 5.000 & & & 22.000 \\
\hline South Africa* & 50.000 & 34.710 & 4.290 & & & 89.000 \\
\hline Spain & 11.000 & 375.000 & 16.000 & & & 402.000 \\
\hline Sweden & 24.993 & 13.126 & 8.183 & & & 46.302 \\
\hline Switzerland & 12.057 & 135.355 & 10.285 & 11.000 & & 168.697 \\
\hline Taiwan & & 104.214 & 12.305 & & & 116.519 \\
\hline Thailand & & 14.650 & & & & 14.650 \\
\hline Tunisia & & 70.188 & 14.812 & & & 85.000 \\
\hline Turkey* & & 1.633 .050 & & & & 1.633 .050 \\
\hline United Kingdom & & 51.975 & 37.125 & & & 89.100 \\
\hline United States & 856.517 & 159.471 & 26.728 & & 1.793 & 1.044 .509 \\
\hline Uruguay & & 7.235 & & & & 7.235 \\
\hline Zimbabwe & & 217 & 138 & & & 355 \\
\hline TOTAL & 2.175 .502 & 9.901 .667 & 40.833 .754 & 57.209 & 20.302 & 52.988 .434 \\
\hline
\end{tabular}

*revised due to new / adapted database in 2012

Table 16: Newly installed collector area in 2009 [m²/a] 


\begin{tabular}{|c|c|c|c|c|c|c|}
\hline \multirow{2}{*}{ Country } & \multicolumn{3}{|c|}{ Water Collectors } & \multicolumn{2}{|c|}{ Air Collectors } & \multirow{2}{*}{ TOTAL $\left[\mathrm{m}^{2}\right]$} \\
\hline & unglazed & glazed & evacuated tube & unglazed & glazed & \\
\hline Albania & & $69.705,0$ & 466,0 & & & 70.171 \\
\hline Australia & $4.720 .000,0$ & $2.443 .568,9$ & $73.806,1$ & & & 7.237.375 \\
\hline Austria & $616.952,0$ & $3.634 .012,4$ & $54.827,5$ & 378,0 & & 4.306 .170 \\
\hline Barbados & & $131.690,0$ & & & & 131.690 \\
\hline Belgium & $46.874,9$ & $252.620,0$ & $25.713,3$ & & & 325.208 \\
\hline Brazil* & $783.403,0$ & $4.392 .993,0$ & & & & 5.176 .396 \\
\hline Bulgaria & & $38.336,0$ & & & & 38.336 \\
\hline Canada & $582.351,0$ & $36.569,0$ & $6.995,0$ & $217.989,0$ & $2.349,0$ & 846.253 \\
\hline Chile* & & $26.730,0$ & & & & 26.730 \\
\hline China & & $13.806 .331,7$ & $131.193 .668,3$ & & & 145.000 .000 \\
\hline Cyprus & & $854.637,0$ & $3.883,1$ & & & 858.520 \\
\hline Czech Republic & $14.620,8$ & $148.646,4$ & $33.030,4$ & & & 196.298 \\
\hline Denmark & $20.515,2$ & $459.865,6$ & $7.684,0$ & $3.264,0$ & $18.000,0$ & 509.329 \\
\hline Estonia & & $1.951,2$ & 390,0 & & & 2.341 \\
\hline Finland & $11.779,2$ & $26.118,4$ & $2.342,4$ & & & 40.240 \\
\hline France incl. DOM* & $92.897,3$ & $1.825 .836,0$ & $54.900,0$ & & & 1.973 .633 \\
\hline Germany* & $663.552,0$ & $10.726 .731,0$ & $1.206 .422,8$ & & $33.600,0$ & 12.630 .306 \\
\hline Greece & & $4.062 .200,0$ & $14.800,0$ & & & 4.077 .000 \\
\hline Hungary & $5.688,0$ & $105.011,0$ & $23.803,0$ & 500,0 & 200,0 & 135.202 \\
\hline India & & $2.838 .948,0$ & $242.247,0$ & & $16.320,0$ & 3.097 .515 \\
\hline Ireland & & $85.475,2$ & $35.492,5$ & & & 120.968 \\
\hline Israel* & $29.900,0$ & $4.087 .895,0$ & & 450,0 & & 4.118 .245 \\
\hline Italy & $43.765,5$ & $1.804 .597,0$ & $252.981,5$ & & & 2.101 .344 \\
\hline Japan & & $5.622 .949,0$ & $97.297,0$ & & $472.376,0$ & 6.192 .622 \\
\hline Jordan & & $689.371,2$ & $205.916,1$ & & & 895.287 \\
\hline Korea, South & & $1.496 .513,9$ & & & & 1.496 .514 \\
\hline Latvia & & $6.904,0$ & 140,0 & & & 7.044 \\
\hline Lebanon** & & $348.312,0$ & & & & 348.312 \\
\hline Lithuania & & $4.168,4$ & 150,0 & & & 4.318 \\
\hline Luxembourg & & $24.482,0$ & $1.818,0$ & & & 26.300 \\
\hline Macedonia & & $25.020,1$ & 723,8 & & 4,0 & 25.748 \\
\hline Malta & & $33.144,0$ & $11.723,0$ & & & 44.867 \\
\hline Mexico & $572.091,9$ & $619.432,5$ & $70.430,0$ & & $5.403,0$ & 1.267 .357 \\
\hline Morocco** & & $272.000,0$ & & & & 272.000 \\
\hline Namibia & & $15.258,7$ & 447,2 & & & 15.706 \\
\hline Netherlands & $377.287,0$ & $378.051,0$ & & & & 755.338 \\
\hline New Zealand & $7.025,4$ & $142.975,3$ & $9.644,4$ & & & 159.645 \\
\hline Norway & $1.920,0$ & $13.010,0$ & 540,0 & & $1.110,0$ & 16.580 \\
\hline Poland & & $394.188,0$ & $115.648,0$ & & & 509.836 \\
\hline Portugal* & $2.081,5$ & $544.703,3$ & $19.362,7$ & & & 566.148 \\
\hline Romania & & $85.496,0$ & $9.000,0$ & & & 94.496 \\
\hline Slovakia & & $107.891,8$ & $12.854,6$ & & & 120.746 \\
\hline Slovenia & & $135.656,0$ & $9.041,6$ & & & 144.698 \\
\hline South Africa & $753.678,2$ & $288.709,8$ & $20.972,0$ & & & 1.063 .360 \\
\hline Spain & $111.000,0$ & $1.885 .000,0$ & $116.000,0$ & & & 2.112 .000 \\
\hline idctlparSweden & $125.000,0$ & $241.000,0$ & $49.000,0$ & & & 415.000 \\
\hline Switzerland & $211.790,0$ & $621.780,0$ & $38.290,0$ & $859.000,0$ & & 1.730 .860 \\
\hline Taiwan & $1.937,0$ & $1.856 .659,3$ & $64.167,7$ & & & 1.922 .764 \\
\hline Thailand & & $91.391,8$ & & & & 91.392 \\
\hline Tunisia & & $384.000,0$ & $21.000,0$ & & & 405.000 \\
\hline Turkey* & & $12.214 .904,0$ & & & & 12.214 .904 \\
\hline United Kingdom & & $364.138,2$ & $95.445,0$ & & & 459.583 \\
\hline United States & $17.793 .589,1$ & $2.553 .983,8$ & $87.755,3$ & & $97.877,6$ & 20.533 .206 \\
\hline Uruguay & & $12.096,0$ & & & & 12.096 \\
\hline Zimbabwe & & $17.509,0$ & 162,0 & & & 17.671 \\
\hline TOTAL & 27.589.699 & 83.351 .167 & 134.290 .981 & 1.081 .581 & 647.240 & 246.960 .668 \\
\hline
\end{tabular}

* revised due to new / adapted database in 2012

** new 2012

Table 17: Total collector area in operation by the end of $2009\left[\mathrm{~m}^{2}\right]$ 


\subsection{References to reports and persons that have supplied the data}

The production of the solar heat worldwide report edition 2012 was kindly supported by national representatives of the recorded countries or other official sources of information as cited below.

COUNTRY

Albania

Australia

Austria

Belgium

Brazil

Bulgaria

Canada

Chile

China

Cyprus

Czech Republic

Denmark

Estonia

Finland

France incl. DOM
CONTACT

Edmond M. Hido

Sonja Ott

Werner Weiss;

Manuela Eberl

ESTIF 2011

new installed according to ESTIF 2011;

total installed projected from AEE INTEC database

Marcelo Mesquita; Ronaldo Yano Toraiwa

Gestor do DASOL - Depto. Nac. Aquecimento Solar da ABRAVA

Data of 2011 version of this report revised according to database of DASOL/ ABRAVA;

ESTIF 2011 (estimation)

new installed according to ESTIF 2011;

total installed projected from AEE INTEC database

Natural Resources Canada; SAIC Canada

SAIC Survey of Active Solar Thermal Collectors,

Industry and Markets in Canada (2010); Reda Djebbar, Doug McClenahan

http://www.cdt.cl/cdt/uploads/anuario_solar_2011.pdf Data of 2011 version of this report revised accordingly

Center for Renewable Energy Development - Energy Research Institute (NDRC)

Soteris Kalogirou, PhD, DSc Cyprus University of Technology

Tomas Matuska

Ministry of Industry and Trade; Bufka, A.: Solar collectors in

2010 - statistical review

new installed according to ESTIF 2011;

total installed projected from AEE INTEC database

Danish Solar Heating Association / ESTIF 2011

new installed according to Danish Solar Heating Association;

total installed projected from AEE INTEC database

ESTIF 2011 (estimation)

new installed according to ESTIF 2011;

total installed projected from AEE INTEC database

ESTIF 2011 (estimation)

new installed according to ESTIF 2011;

total installed projected from AEE INTEC database

ADEME - Centre de Sophia Antipolis / ESTIF 2011

Unglazed water collectors from historic AEE INTEC recordings; France overseas dept. according to ESTIF estimations 
Germany

Greece

Hungary

India

Ireland

Israel

Italy

Japan

Jordan

Korea, South

Latvia

Lebanon

Lithuania

Luxembourg

Malta

Mexico

Morocco

Namibia
Jan Knaack;

Harald Drück

Costas Travasaros; Vassiliki Drosou

Pál Varga

Ministry Of New and

Renewable Energy

Emer Dennehy

Eli Shilton

Valeria Verga / ESTIF 2011 Associazione Italiana Solare Termico (Assolterm) / ESTIF 2011

Yamashita Noriaki

Nidal Abdalla

ESTIF 2010 (estimation)

Adel Mourtada

ESTIF 2010

ESTIF 2010

Godwin Sant

Vicente Estrada-Cajigal

Said Mouline

Kudakwashe Ndhlukula Assolterm-Assotermica market study; Share between types of collectors according to ESTIF 2011

Bundesverband Solarwirtschaft e.V.;

Unglazed water collectors from historic AEE INTEC recordings

(less out of operation collectors since 2007)

Centre for Renewable Energy Sources (CRES) / ESTIF 2011

Hungarian Solar Thermal Industry Federation (MÉGNAP) personal estimation Pál Varga

http://mnre.gov.in/achievements.htm

Energy policy statistical support unit of Sustainable Energy Authority of Ireland

Grant scheme data; GHS and REHEAT programmes; BER database

solar energy systems Itd

Data for 2009 revised according to data from the Interdisciplinary Center for Technological Analysis and Forecasting (ICTAF); Asher Vaturi

Institute for Sustainable Energy Policies (ISEP); Solar System Development Association (SSDA)

http://www.ssda.or.jp/profile/img/b11.pdf

National Energy Research Center (NERC), Department of Statistic Survey

Korea New and Renewable Energy Center (KNREC)

new installed according to Korea New and Renewable Energy Center (KNREC); total installed projected from AEE INTEC database

new installed according to ESTIF 2011;

total installed projected from AEE INTEC database

Lebanese Association for Energy Saving \& for Environment (ALMEE)

Mourtada, A.: Market analysis of Solar Thermal Systems in Lebanon; proceedings ESTEC 2011; Marseille, France

new installed according to ESTIF 2011;

total installed projected from AEE INTEC database

new installed according to ESTIF 2011;

total installed projected from AEE INTEC database

Malta Resources Authority

Asociación Nacional de Energía Solar (ANES)

http://www.anes.org/anes/index.php?option=com_wrapper\&Itemid =13

National Agency for the Development of Renewable Energy and Energy Efficiency (ADEREE)

http://www.solarthermalworld.org/node/2849

Renewable Energy \& Energy Efficiency Institute (REEEI)

REEEI Annual Market Survey 


\begin{tabular}{|c|c|c|}
\hline Netherlands & Reinoud Segers & Statistics Netherlands (CBS) \\
\hline Norway & Peter Bernhard & KanEnergi AS \\
\hline Poland & $\begin{array}{l}\text { Grzegorz Wiśniewski; } \\
\text { Aneta Wiecka }\end{array}$ & EC BREC Institute for Renewable Energy Ltd. \\
\hline Portugal & João Farinha Mendes & Associação Portuguesa da Indústria Solar (APISOLAR) \\
\hline Romania & ESTIF 2009 (estimation) & $\begin{array}{l}\text { new installed according to ESTIF 2011; } \\
\text { total installed projected from AEE INTEC database }\end{array}$ \\
\hline Slovakia & ESTIF 2009 & $\begin{array}{l}\text { new installed according to ESTIF 2011; } \\
\text { total installed projected from AEE INTEC database }\end{array}$ \\
\hline Slovenia & ESTIF 2009 & $\begin{array}{l}\text { new installed according to ESTIF 2011; } \\
\text { total installed projected from AEE INTEC database }\end{array}$ \\
\hline South Africa & Dieter Holm & $\begin{array}{l}\text { SOLTRAIN Southern Africa / The South African Solar Water } \\
\text { Heater Industry } \\
\text { New unglazed water collectors installed in } 2010 \text { estimated by AEE INTEC }\end{array}$ \\
\hline Spain & Pascual Polo & Asociación Solar de la Industria Térmica (ASIT) \\
\hline Sweden & Jan-Olof Dalenbäck & Svensk solenergi; CHALMERS University of Technology \\
\hline Switzerland & Urs Wolfer & $\begin{array}{l}\text { SWISSOLAR } \\
\text { Markterhebung Sonnenergie, } 2009\end{array}$ \\
\hline Taiwan & K.M. Chung & Energy Research Center - National Cheng Kung University \\
\hline Tunisia & Moncef Njaimi & National Agency of Energy Conservation (ANME) \\
\hline Turkey & A. Kutay Ulke & $\begin{array}{l}\text { EZINC Metal San. Tic. A.S. } \\
\text { New and total installed capacity revised according to new database }\end{array}$ \\
\hline United Kingdom & ESTIF 2011 & $\begin{array}{l}\text { new installed according to ESTIF 2011; } \\
\text { total installed projected from AEE INTEC database }\end{array}$ \\
\hline United States & $\begin{array}{l}\text { Solar Energie Industries } \\
\text { Association (SEIA) }\end{array}$ & $\begin{array}{l}\text { http://www. seia.org/galleries/pdf/SMI-YIR-2010-ES.pdf } \\
\text { Historical data from U.S. Department of Energy (DoE) - } \\
\text { Energy Information Administration (EIA) }\end{array}$ \\
\hline Zimbabwe & Anton Schwarzlmüller & DSH, Soltrain \\
\hline
\end{tabular}




\subsubsection{Additional literature and web sources used}

\section{The following reports and statistics were used in this report.}

- Bank Sarasin: Solar Industry: Survival of the fittest in a fiercely competitive marketplace, Bank Sarasin \&Co. Ltd, Switzerland, Basel; November 2011

- Bundesamt für Energie (BFE): Markterhebung Sonnenenergie 2010 - Teilstatistik der Schweizerischen Statistik der erneuerbaren Energien, Switzerland - Bern; July 2011

- Bundesministerium für Verkehr, Innovation und Technologie (BMVIT): Innovative Energietechnologien in Österreich - Marktentwicklung 2010; Wien; May 2011

- European Solar Thermal Industry Federation (ESTIF): Solar Thermal Markets in Europe, Trends and Market Statistics 2010; Belgium - Brussels; June 2011

- Solar Energy Industry Association (SEIA): U.S. Solar Market Insight - 2010 Year in Review; SEIA / GTM Research 2010; http://www.seia.org/cs/research/solarinsight

- REN 21: Renewables 2011 Global Status Report; www.ren21.net/

\section{The following online sources were used in this report:}

- http://www.anes.org/

- http://www.aderee.ma/

- http://www.apisolar.pt/

- $\mathrm{http}: / /$ www.asit-solar.com/

- http://www.cdt.cl/

- http://www.dasolabrava.org.br/

- http://www.estif.org/

- http://mnre.gov.in/

- http://www.olade.org/

- http://www.solar-district-heating.eu/

- http://www.solarwirtschaft.de/

- http://www.solrico.com/

- http://www.solarthermalworld.org/

- http://www.tech4cdm.com/ 


\subsection{List of Figures}

Figure 1: Countries represented in this report

Figure 2: Total capacity in operation [GW el], [GW $\mathrm{Gh}$ ] 2011 and annual energy generated [TWhel], [TWh $\left.\mathrm{Th}_{\mathrm{th}}\right]$.

Sources: EPIA, EGEC, Earth Policy Institute, IEA SHC 2011, WWEA

Figure 3: Share of the total installed capacity in operation (glazed and unglazed water and air collectors)

by economic regions at the end of 2010

Figure 4: Distribution of the total installed capacity in operation by collector type in 2010

Figure 5: Total installed capacity of unglazed and glazed water collectors in operation in the 10 leading countries by the end of 2010

Figure 6: Total capacity of glazed flat plate and evacuated tube collectors in operation by the end of 2010

(note: logarithmic scale of $y$-axis)

Figure 7: Total capacity of glazed flat plate and evacuated tube collectors in operation in $\mathrm{kW}_{\text {th }}$ per 1,000 inhabitants by the end of 2010

Figure 8: Total capacity of glazed flat plate and evacuated tube collectors in operation by economic region at the end of 2010

Figure 9: Total capacity of glazed flat plate and evacuated tube collectors in operation by economic region and in $\mathrm{kW}_{\text {th }}$ per 1,000 inhabitants by the end of 2010

Figure 10: Total capacity of unglazed water collectors in operation by the end of 2010 (note: logarithmic scale of $y$-axis)

Figure 11: Total capacity of unglazed water collectors in operation in $\mathrm{kW}_{\text {th }}$ per 1,000 inhabitants by the end of 2010

Figure 12: Total capacity of unglazed collectors in operation by economic region by the end of 2010

Figure 13: Total capacity of unglazed collectors in operation by economic region and in $\mathrm{kW}_{\text {th }}$ per 1,000 inhabitants by the end of 2010

Figure 14: Market development of the newly installed capacity between 2009 and 2010 by economic region

Figure 15: Share of the newly installed capacity (glazed and unglazed water and air collectors) by economic regions in 2010

Figure 16: Distribution of the newly installed capacity by collector type in 2010

Figure 17: Total capacity of newly installed glazed and unglazed water collectors in the 10 leading countries in $2010 \quad \ldots \ldots \quad 20$

Figure 18: Newly installed capacity of glazed water collectors in 2010 (note: logarithmic scale of $y$-axis) $\ldots \ldots \ldots \ldots \ldots . \ldots 21$

Figure 19: Newly installed capacity of glazed water collectors in 2010 in $\mathrm{kW}_{\text {th }}$ per 1,000 inhabitants $\ldots \ldots \ldots \ldots \ldots \ldots \ldots$

Figure 20: Annual installed capacity of flat plate and evacuated tube collectors from 2000 to $2010 \quad \ldots \ldots \ldots \ldots \ldots \ldots \ldots \ldots$

Figure 21: Annual installed capacity of flat-plate and evacuated tube collectors in China from 1997 to 2011 in comparison to the annual growth rates in China and the World

Figure 22: Annual installed capacity of flat plate and evacuated tube collectors in $\mathrm{kW}_{\text {th }}$ per 1,000 inhabitants from 2000 to 2010

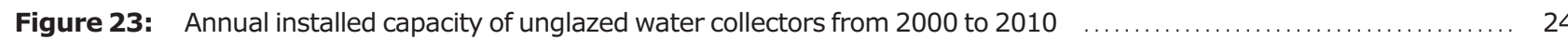

Figure 24: Annual collector yield of glazed (FPC + ETC) water collectors in operation by economic region in $2010 \quad \ldots \ldots \ldots \quad 29$

Figure 25: Annual collector yield of glazed (FPC + ETC) water collectors in operation by economic region in MWh per 1,000 inhabitants in 2010

Figure 26: Annual collector yield of unglazed water collectors in operation by economic region in 2010

Figure 27: Annual collector yield of unglazed water collectors in operation by economic region in MWh per 1,000 inhabitants in 2010

Figure 28: Annual energy savings in oil equivalent by glazed (FPC + ETC) water collectors in operation by economic region in 2010

Figure 29: Annual energy savings in oil equivalent by glazed (FPC + ETC) water collectors in operation by economic region per 1,000 inhabitants in 2010

Figure 30: Annual energy savings in oil equivalents by unglazed water collectors in operation by economic region in 2010 
Figure 31: Annual energy savings in oil equivalent by unglazed water collectors in operation by economic region per 1,000 inhabitants in 2010

Figure 32: Contribution to $\mathrm{CO}_{2}$ reduction by glazed (FPC $+\mathrm{ETC}$ ) water collectors in operation by economic region in 2010

Figure 33: Contribution to $\mathrm{CO}_{2}$ reduction by glazed (FPC $+\mathrm{ETC}$ ) water collectors in operation by economic region per 1,000 inhabitants in 2010

Figure 34: Contribution to $\mathrm{CO}_{2}$ reduction by unglazed water collectors in operation by economic region in 2010

Figure 35: Contribution to $\mathrm{CO}_{2}$ reduction by unglazed water collectors in operation by economic region per

1,000 inhabitants in 2010

Figure 36: Distribution by type of solar thermal collector for the total installed water collector capacity in operation by the end of 2010

Figure 37: Distribution by type of solar thermal collector for the total installed glazed (FPC + ETC) water collector capacity in operation by the end of 2010

Figure 38: Distribution by type of solar thermal collector for the newly installed water collector capacity in 2010

Figure 39: Distribution by type of solar thermal collector for the newly installed glazed (FPC + ETC) water collector capacity in 2010

Figure 40: Distribution by type of system for the total installed water collector capacity in operation by the end of 2010

Figure 41: Distribution by type of system for the newly installed water collector capacity in 2010

Figure 42: Distribution of solar thermal systems by application for the total installed glazed water collector capacity in operation by the end of 2010

Figure 43: Distribution of solar thermal systems by application for the 10 leading markets of the total installed glazed water collector capacity in operation by the end of 2010

Figure 44: Distribution of different applications of the newly installed capacity of glazed water collectors by economic region in 2010

Figure 45: Distribution of different applications of the newly installed capacity of glazed water collectors for the 8 leading countries worldwide in 2010

Figure 46: Distribution of different applications of the newly installed capacity of glazed water collectors for the 8 leading European countries in 2010

Figure 47: European large-scale solar heating plants by the end of 2010 (Source: Jan-Olof Dalenbäck - Chalmers University of Technology)

Figure 48: Market development of small to large-scale solar air conditioning and cooling systems worldwide as well as in Europe (Source: Solem Consulting / Climasol, Fraunhofer ISE, Rococo, Tecsol)

Figure 49: Hydraulic scheme of the swimming pool reference system 46

Figure 50: Hydraulic scheme of the DHW pumped reference system 48

Figure 51: Hydraulic scheme of the DHW thermosiphon reference system

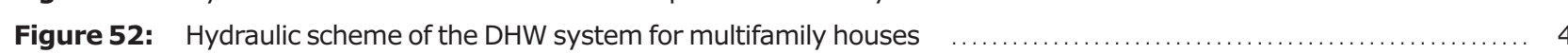

Figure 53: Hydraulic scheme of the solar combi reference system 


\subsection{List of Tables}

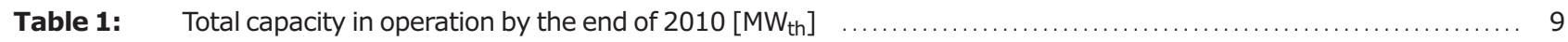

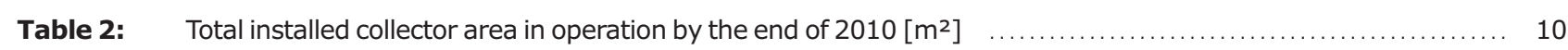

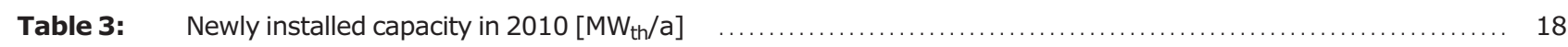

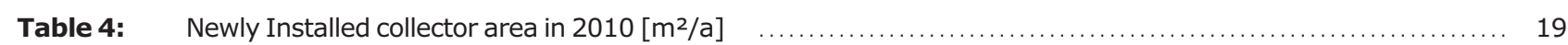

Table 5: Calculated annual collector yield and corresponding oil equivalent as well as $\mathrm{CO}_{2}$ reduction of glazed

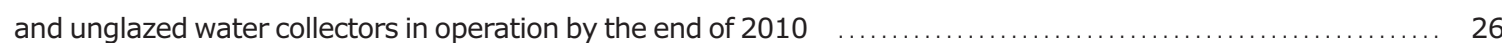

Table 6: Calculated annual collector yield and corresponding oil equivalent as well as $\mathrm{CO}_{2}$ reduction of glazed (FPC + ETC) water collectors in operation by the end of 2010

Table 7: Calculated annual collector yield and corresponding oil equivalent as well as $\mathrm{CO}_{2}$ reduction of unglazed water collectors in operation by the end of 2010

Table 8: Solar thermal swimming pool heating reference systems with unglazed water collectors and the total collector area in operation by the end of 2010

Table 9: Domestic hot water reference systems for single family houses and the total collector area in operation by the end of 2010

Table 10: Domestic hot water reference systems for multifamily houses, hotels and district heating and the total collector area in operation in 2010

Table 11: Solar combi reference systems for single and multifamily houses and the total collector area in operation in 2010

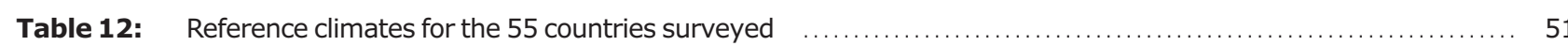

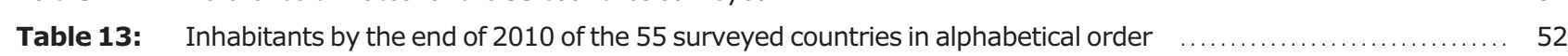

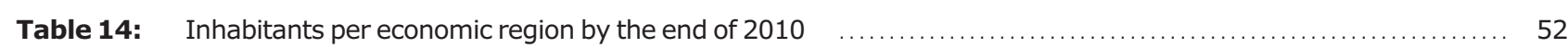

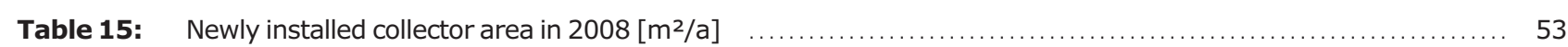

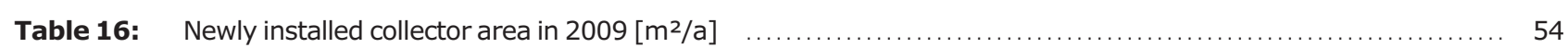

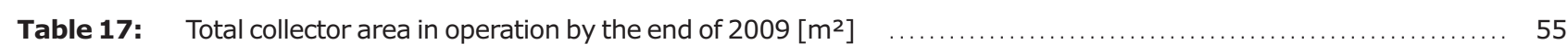

